\title{
WestVirginiaUniversity
}

THE RESEARCH REPOSITORY @ WVU

Graduate Theses, Dissertations, and Problem Reports

2011

\section{Dwindling into a Wife: Women and the Culture of Marriage in Britain, 1760-1820}

Lori Halvorsen Zerne

West Virginia University

Follow this and additional works at: https://researchrepository.wvu.edu/etd

\section{Recommended Citation}

Zerne, Lori Halvorsen, "Dwindling into a Wife: Women and the Culture of Marriage in Britain, 1760-1820" (2011). Graduate Theses, Dissertations, and Problem Reports. 4822.

https://researchrepository.wvu.edu/etd/4822

This Dissertation is protected by copyright and/or related rights. It has been brought to you by the The Research Repository @ WVU with permission from the rights-holder(s). You are free to use this Dissertation in any way that is permitted by the copyright and related rights legislation that applies to your use. For other uses you must obtain permission from the rights-holder(s) directly, unless additional rights are indicated by a Creative Commons license in the record and/ or on the work itself. This Dissertation has been accepted for inclusion in WVU Graduate Theses, Dissertations, and Problem Reports collection by an authorized administrator of The Research Repository @ WVU.

For more information, please contact researchrepository@mail.wvu.edu. 
Dwindling into a Wife: Women and the Culture of Marriage in Britain, 1760-1820

\title{
Lori Halvorsen Zerne
}

Dissertation submitted to the Eberly College of Arts and Sciences at West Virginia University in partial fulfillment of the requirements for the degree of

\author{
Doctor of Philosophy \\ in \\ English
}

\author{
Marilyn Francus, Ph.D. Chair \\ Dennis Allen, Ph.D. \\ Katharine Kittredge, Ph.D. \\ Adam Komisaruk, Ph.D. \\ Valerie Lastinger, Ph.D.
}

Department of English

\author{
Morgantown, West Virginia \\ 2011
}

Keywords: Austen, Jane; Burney, Frances; Edgeworth, Maria; Scott, Sarah; Courtship

Narrative; Marriage; Ideology; Chaperon; Mother-in-Law; Governess; Spinster

Copyright 2011 Lori Halvorsen Zerne 


\section{ABSTRACT \\ Dwindling into a Wife: Women and the Culture of Marriage in Britain, 1760-1820}

\section{Lori Halvorsen Zerne}

This dissertation examines women and marriage ideology in courtship novels of the late eighteenth and early nineteenth centuries, specifically novels by Sarah Scott, Frances Burney, Maria Edgeworth, and Jane Austen. Instead of focusing on the heroines of these courtship novels, however, this project explores the marginalized female roles that orbit the courtship narrative: the chaperon, the mother-in-law, the governess, and the spinster. These four roles demonstrate the broad scope of female functions and services in the period while also calling into question the ideology that attempts to limit women only to the role of wife. The chaperon reveals the work necessary to succeed in courtship, which challenges the idea that courtship and marriage are easy and natural; the mother-in-law challenges both the culture of marriage and patriarchal ideology more generally through her maternal authority, which conflicts with male authority; the governess demonstrates the contradiction of teaching her pupils skills that did not lead to her own success on the marriage market; and the spinster calls into question the ideology that the role of wife is inevitable and mandatory. While the narratives of these four roles merit recuperation and attention in their own right, more significantly, this analysis offers a more complete and nuanced examination of the culture of marriage, by exploring alternatives and challenges to marriage, revealing the actual cultural roles of marginalized leisure-class women, and identifying the ways in which the ideology of marriage was both maintained and challenged in eighteenth- and nineteenth-century England. Ultimately, this study exposes the cultural pressures and processes by which the concepts of marriage have been shaped and, at times, distorted. 


\section{Acknowledgements}

Completing this dissertation would have been impossible without the patient encouragement of my supervisor, Marilyn Francus. I am also grateful for the hours she spent reading and responding to drafts, helping me to clarify and articulate my arguments. I also thank my other committee members: Dennis Allen, whose feedback as my second primary reader was invaluable in making the chapters more cogent; Katharine Kittredge, whose detailed editing and critique was most helpful; and Adam Komisaruk and Valerie Lastinger, whose suggestions for further direction of the project were lucid and welcome. Lastly, I am forever indebted to John for his unwavering love and support. 


\section{Table of Contents}

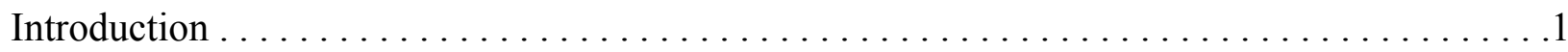

Chapter 1: Guardian, Mentor, Matchmaker: Marriage Ideology, the Chaperon, and Dissent in

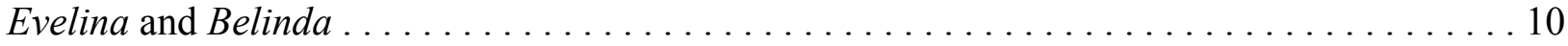

Chapter 2: "This Formidable Mother-in-Law": Marriage Ideology, the Mother-in-Law, and

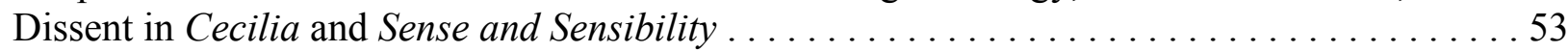

Chapter 3: "What Have I To Do with Matrimony?”: Marriage Ideology, the Governess, and

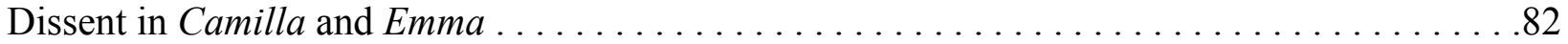

Chapter 4: A Famous Formal Quiz: Marriage Ideology, the Spinster, and Dissent in Millenium

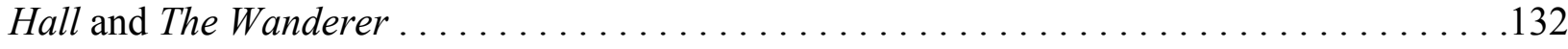

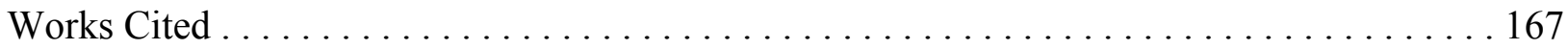




\section{Introduction}

Marriage was arguably the defining activity of female existence in the latter part of the long eighteenth century. Generally society expected women, especially of the leisure class, to marry, and those who did not were often viewed as failed women. The expectation that women would marry, along with the assumption that marriage formed a large part of a woman's identity, characterize a sociological phenomenon that I call a culture of marriage in the period. The eighteenth-century focus on marriage served to minimize or even erase other female identities, though such erasure was not absolute, uncomplicated, or always accepted. In the famous proviso scene in William Congreve's 1700 play The Way of the World, Millamant memorably refers to the expected loss of her identity upon marriage when she tells Mirabel, "I may by degrees dwindle into a wife" (Act IV, scene 5).

The saturation of the culture of marriage in eighteenth-century English society is evident in the conduct literature, which carefully prescribes three "proper" roles for women: daughter, wife, and widow. ${ }^{1}$ These three "normative" roles are clearly defined by a woman's relationship to a man — who is a father, a husband, or a dead husband. Other women's roles—-such as sister, aunt, or even mother, let alone professional roles, such as governess, actress, or writer—are often overlooked. Richard Allestree organizes his conduct manual The Ladies Calling (1673) into three sections: "Of Virgins," "Of Wives," and "Of Widows." He conflates the important role of mother into that of wife, and he completely ignores other roles for women. Like the conduct manuals, most novels of the period also emphasize the importance of marriage for women. ${ }^{2}$ Many eighteenth-century novels from Fielding to Austen include courtship narratives (and significantly, there are few strictly marital narratives), and conduct literature prescribes appropriate behavior for women on the marriage market as well as for wives once they are 
married. In his Advice to a Daughter (1688), the Marquis of Halifax includes advice on proper behavior for leisure-class women in such chapters as "Behaviour and Conversation," "Friendships," "Censure," "Vanity and Affectation," "Pride," and "Diversions." However, Halifax makes it clear that "correct" behavior is closely connected to women's position in a patriarchal world (despite the flaws that he sees in the patriarchy): the first three chapters of the book, which immediately precede those listed above, are titled "Religion," "Husband," and “House, Family, and Children.” These chapters emphasize women's place in eighteenth-century England: she must submit to God and to her husband, and her purpose is creating, and to an extent rearing, the next generation of Britons.

The attention given to marriage in the period signals ideological concerns. Many historians and literary critics, such as Lawrence Stone, Randolph Trumbach, Edward Shorter, Alan McFarlane, Nancy Armstrong, Christopher Flint, and Ruth Perry, have noted that definitions of the family were in flux during the eighteenth and early nineteenth centuries. Furthermore, marriage rates dropped from an average of 9.2 marriages per 1000 people in the 1760s to 8.1 per 1000 in the 1810 s (Wrigley and Schofield 534). In the face of this ideological and social instability, the culture emphasized the importance of marriage for women at the expense of other roles. In the patriarchal society women, rather than men, seem to have been tacitly blamed for any ideological shift. One way that the culture of marriage is revealed in the period is through the development of and popularity of the courtship novel. Katherine Sobba Green describes courtship novels as "written by women and for women" (2). These novels emphasize the social importance of courtship. Marriage is an important social marker for women in the period, yet these novels, by focusing on the activities of courtship rather than of 
marriage, suggest that women spend more time focusing on courtship — how and whom to marry - than on marriage itself or on why and how to be a wife.

Previous studies of the courtship novel—such as Nancy Armstrong's Desire and Domestic Fiction: A Political History of the Novel (1987), Katherine Sobba Green's The Courtship Novel, 1740-1820: A Feminized Genre (1991), and Susan Greenfield's Mothering Daughters: Novels and the Politics of Family Romance, Frances Burney to Jane Austen (2002) - have typically focused on the courting heroine, thereby continuing the marginalization of the women who often enable and shape her courtship. While recent scholarship has, to some degree, expanded our understanding of marriage and family in eighteenth-century England, here too the emphasis remains on the woman's role as wife. In her book Novel Relations: The Transformation of Kinship in English Literature and Culture, 1748-1818 (2006), Ruth Perry proposes that during the eighteenth century the meaning of "family" in England changed from placing an emphasis of consanguineal ties to focusing on conjugal ties. For Perry, this stronger focus on the conjugal family results in a stronger focus on marriage for all, and more specifically, on the role of wife for women at the expense of other possible identities and roles. Yet Perry does not examine the implications of this transformation for women's roles outside of the immediate family (except for aunts, whom she sees as surrogate mothers) and their identity options. Similarly, historian Amy M. Froide's book Never Married: Singlewomen in Early Modern England (2007) emphasizes the cultural importance of marriage in the period by positing that marital status served as much as a category of difference as gender or race. By examining women who did not marry, Froide's work emphasizes the constructed nature of marriage and courtship ideologies in the period. However, she largely ignores the contribution of courtship novels to that ideological work. My study responds to these gaps in scholarship by 
analyzing marginalized female characters in popular courtship novels at the end of the long eighteenth century: the chaperon, the mother-in-law, the governess, and the spinster. As these women contribute to and call into question marriage ideology, they extend our understanding of the constructed and unstable nature of that ideology.

In his book Faultlines: Cultural Materialism and the Politics of Dissident Reading (1992), Alan Sinfield examines the conflicts in ideology that are repeatedly reflected in early modern literature. He argues that literature is a valuable source for evaluating a culture because This is how culture elaborates itself. In these texts, through diverse genres and institutions, people were talking to each other about an aspect of their life that they found hard to handle. When a part of our worldview threatens disruption by manifestly failing to cohere with the rest, then we reorganize and retell its story, trying to get it into shape — - back into the old shape if we are conservative-minded, or into a new shape if we are more adventurous. (46)

During the second half of the long eighteenth century, not only did the novel continue to increase in popularity and acceptance, but the subgenre of the courtship novel became particularly prevalent. In light of Sinfield's explanation of the relationship between text and cultural disruption, this growth makes sense: as the first major genre of literature to be open to significant numbers of female writers, the novel naturally focused on the ideological issue of most concern to women in eighteenth-century Britain: marriage.

The proliferation of courtship novels indicates tensions within marriage ideology, since "the topics that engaged writers and audiences alike were those where ideology was under strain" (114). Sinfield defines ideology as the set of ideas and practices that "produces, makes plausible, concepts and systems to explain who we are, who the others are, how the world works." He 
continues to explain that the "strength of ideology derives from the way it gets to be common sense" (32). In eighteenth-century England the "common sense" expectation for a woman included marriage. Sinfield's analysis of the relationship between ideology and institutions of power helps explain the strength of the ideology of marriage in the eighteenth century: "Ideology is produced everywhere all the time in the social order, but some institutions - by definition, those that usually corroborate the prevailing power arrangements—are vastly more powerful than others [e.g. state and church]. The stories they endorse are more difficult to challenge, even to disbelieve" (33). The endorsement of both church (through religious teachings that emphasize sexual morality and purity, especially for women) and state (through patriarchal laws about inheritance and bastardy as well as laws promoting sexual morality, again especially for women) made the ideology of marriage particularly difficult to challenge. Patriarchal power must make the ideology of marriage as strong as possible because of the necessity to maintain that power.

Yet, as Sinfield points out in his analysis of what he calls Desdemona's "divided duty" between father and husband in Othello, the patriarchal ideology of marriage is based on a faultline: "Marriage was the institution through which property arrangements were made and inheritance secured, but it was supposed also to be a fulfilling personal relationship. It was held that the people being married should act in obedience to their parents, but also that they should love each other" (43). This contradiction makes marriage "an insecure moment in patriarchy" (42). The divided duty faultline reveals a contradiction in marriage ideology, even as it ultimately leaves intact the ideology that a woman should marry. Women in eighteenth-century England not only faced the question of whether they would marry a man chosen by their father or themselves, but more fundamentally for leisure-class women at a time of declining marriage rates, they confronted the question of whether they could or would marry at all. Thus, the 
courtship novels of the latter part of the long eighteenth century address not merely the issue of the configuration of the family (the focus of Perry's study) but also the naturalness, pleasantness, and viability of the institution of marriage. Sinfield points out that the "principle strategy of ideology is to legitimate inequality and exploitation by representing the social order that perpetuates these things as immutable and unalterable - as decreed by God or simply natural" (114). Marriage ideology in the eighteenth century is promoted as both "decreed by God" and "natural," but the ideology hides the work involved not only in marriage but also in courtship, work that the minor characters in courtship novels can reveal.

Courtship narratives reinforce the ideology through the heroine's or hero's marriage at the conclusion, but minor characters in the novel provide a space to question the ideology of marriage. As Sinfield notes, "the social order cannot but produce faultlines through which its own criteria of plausibility fall into contest and disarray" (45). However, such "[d]issident opportunities are always limited — otherwise we would not be living as we do" (45). Courtship is an unstable moment in patriarchy because it gives power, limited though it is, to women: not only did the woman being wooed possess the power of refusal, but female parents, guardians, and instructors also could and did wield some power. The ideological importance of the characters of the chaperon, the mother-in-law, the governess, and the spinster reveals faultlines within and opens space for dissent from the culture of marriage.

In my first chapter, “Guardian, Mentor, Matchmaker: Marriage Ideology, the Chaperon, and Dissent in Evelina and Belinda," I argue that the chaperon is vital to courtship narrative; she propels the plot by taking the young female protagonist to the urban centers of the marriage market. Without her, the heroine would not meet her future husband. In aiding of courtship narrative, the chaperon has three primary duties: she serves as a guardian, a mentor, and a 
matchmaker to her charge. Each of these duties is fraught with contradictions that reveal faultlines in marriage ideology. The chaperons in Burney's Evelina (1778) and Edgeworth's Belinda (1801) perform their duties with varying degrees of success, but together they reveal the work of the chaperon and how that work calls into question marriage ideology.

The second chapter, “'This Formidable Mother-in-Law': Marriage Ideology, the Motherin-Law, and Dissent in Cecilia and Sense and Sensibility," examines the space that the motherin-law inhabits between the displaced authority of the mother and ascendant authority of the husband. This chapter analyzes overpowering mothers-in-law in Burney's Cecilia (1782) and Austen's Sense and Sensibility (1811) who attempt, with varying degrees of success, to influence the marriages of their children. As they assert the importance of marriage as an institution, these women simultaneously challenge the authority of husbands, sons, and sons-in-law to control their own marriages and marital choices. The powerful mother-in-law emphasizes parental, but not necessarily patriarchal, control over adult children; she challenges the authority of the patriarch and interrogates the gender roles and power structure assigned to marriage in patriarchal eighteenth-century society.

In the third chapter, “'What Have I To Do with Matrimony?': Marriage Ideology, the Governess, and Dissent in Camilla and Emma," I explore the governess's deep entanglement in courtship and marriage ideologies, as well as her ambivalent position in class ideology. Although the governesses in Burney's Camilla (1796) and Austen's Emma (1816) are relatively minor characters in the novels, they nevertheless challenge the ideology that marriage is natural by revealing the work that courtship requires for a leisure-class woman to attain the "natural" role of wife. The governess's work demonstrates the ideological contradiction of her teaching her pupils skills that failed to lead to her own success on the marriage market. By presenting an 
alternative to marriage that inevitably reveals a degree of female agency, the governess reveals space for dissent from class and marriage ideologies.

The final chapter, "A Famous Formal Quiz: Marriage Ideology, the Spinster, and Dissent in Millenium Hall, Emma, and The Wanderer," examines women who do not marry despite the cultural and ideological emphasis on marriage as the fulfillment of female duty. These women, subject neither to husbands nor fathers, demonstrate a kind of authority. The unmarried inhabitants of the estate in Scott's Millenium Hall (1762) represent a utopian alternative to marriage and in doing so redefine female duty, while the spinsters in Austen's Emma and Burney's The Wanderer (1814) serve as foils to their respective heroines in ways that question class as well as marriage ideology. Thus, the spinster challenges the ideology that the role of wife is inevitable and desirable.

While the narratives of these four roles merit recuperation and attention in their own right, my analysis also offers a more complete and nuanced view of the culture of marriage in the period, by revealing the cultural roles of marginalized leisure-class women, and identifying the ways in which the ideology of marriage was both maintained and challenged in eighteenthcentury England. By demonstrating the insecurity of courtship and marriage ideologies, my project suggests explanations for certain social anxieties, and for the cultural insistence on the correct performance of ideological behaviors and the marginalization of those who fail in their performance. Since we are heirs of these constructs of courtship and marriage, my research thus expands our understanding of our own constructions of marriage, which is especially valuable since, once again, the definition and ideology of marriage are shifting.

\footnotetext{
${ }^{1}$ Although the specific texts referenced here were written during the Restoration, they were reprinted and read throughout the long eighteenth century.
} 
${ }^{2}$ Courtship novels of the late eighteenth and early nineteenth centuries abound with older women who determine to marry off the young women in their charge, such as Mrs. Bennet in Pride and Prejudice ("The business of her life was to get her daughters married" [5]), Mrs. Jennings in Sense and Sensibility ("[I]f I don't get one of you at least well married before I have done with you, it shall not be my fault" [153-54]), Mrs. Stanhope in Belinda ("She prided herself upon having established half a dozen nieces most happily; that is to say, upon having married them to men of fortunes far superior to their own" [7]), and Miss Margland in Camilla (she regularly accosts Sir Hugh with exhortations on "the necessity of bringing the young ladies out, and the duty of thinking of their establishment" [54]). These women recognize the importance of marriage to the construction of female life in the period, and they accept it uncritically. 


\section{Chapter 1}

\section{Guardian, Mentor, Matchmaker: Marriage Ideology, the Chaperon, and Dissent in Evelina and Belinda}

When Mrs. Jennings proposes taking Elinor and Marianne Dashwood with her to London in Austen's Sense and Sensibility (1811), she asserts: "I am sure your mother will not object to it; for I have had such good luck in getting my own children off my hands, that she will think me a very fit person to have the charge of you; and if I don't get one of you at least well married before I have done with you, it shall not be my fault" (153-54). In one sentence Mrs. Jennings defines her role as chaperon in early nineteenth-century Britain. The chaperon, usually an older married or widowed woman, temporarily replaces the mother as the guardian of young women in order to take them to the center of the marriage market—primarily London, but also spa towns such as Bath, Bristol Hotwells, and Brighton—so that they will have a better opportunity of finding husbands. Her charge is to protect the young women from urban dangers (specifically predatory men), advise them about courtship, and guide them through the urban social scene. ${ }^{1}$ Yet more often than not, young women are insufficiently chaperoned in the novels of the period, leaving them to face dangers to both their reputations and their physical safety, which in turn threatens their chance at making a suitable marriage. ${ }^{2}$ Through her actions (and her inaction), the chaperon provides insight into marriage ideology in British culture and the courtship novels of the period.

Although the chaperon has a specific role in the British marriage system of the latter part of the long eighteenth century, she has been largely ignored by historians and literary critics. The primary exception is Ruth Perry's chapter on aunts in her book Novel Relations, and even Perry subsumes chaperons into a broader category of aunts who function as guardians and 
mentors to heroines in the absence of the mother. She convincingly argues that aunts function only to support the heroine, which the mother cannot do:

The yearning created by maternal absence in these fictions is sometimes supplied in the text by an older woman who is not the heroine's mother, but who guides and advises her, and stands in the place of a mother to her. As if called into being by a need that could be assuaged no other way, these older women - these symbolic 'aunts' - have no narrative purpose except to give their support and appreciation to the poor, motherless heroine. (347)

While Perry makes a compelling argument about metaphorical aunts in courtship novels, her analysis shortchanges the chaperon and overlooks her specific contribution to marriage ideology. ${ }^{3}$ Chaperons were more than a literary device in the period; they were an established custom, for some mothers died before they could accompany their daughters to the urban centers of the marriage market, and many mothers were too busy with younger children, disinclined to travel, or too poor to live in the city.

In aiding courtship narrative, the chaperon has three primary duties: she serves as a guardian, a mentor, and a matchmaker to her charge. Each of these duties is fraught with contradiction, and each reveals faultlines in marriage ideology. Of course, chaperons perform their duties with varying degrees of success. In Frances Burney's novel Evelina (1778) and Maria Edgeworth's Belinda (1801) both titular heroines visit the city under the care of multiple chaperons. These chaperons-Mrs. Mirvan, Madame Duval, and Mrs. Selwyn in Evelina, and Lady Delacour and Lady Anne Percival in Belinda - vary in their performance of their duty as chaperons, but together they reveal the work of the chaperon and the ways that work calls into question marriage ideology. 


\section{"How Easily and How Frequently She Is Deceived": The Chaperon as Guardian}

In many respects the most important responsibility of the chaperon is to protect the young woman from urban dangers to her body and her reputation. This duty reveals a glaring faultline in courtship ideology: by taking a young woman to the city, the chaperon not only introduces her to potential husbands, but to potential seducers who could destroy her chances of marriage.

Thus, the chaperon puts the heroine into dangerous situations from which she must protect her charge. An unscrupulous or inattentive chaperon would be blamed for the ruin of her charge, as in Pride and Prejudice, where two chaperons fail as guardians, and are censured accordingly: Mrs. Forster, who, through her inattention, allows Lydia to elope with Wickham, and Mrs. Younge, who aids Wickham's plan to elope with Georgiana (201-02, 273-93).

Even chaperons who do not allow their charges to elope may expose their charges to danger. In Burney's novel Mrs. Mirvan takes Evelina to Mrs. Stanley's private ball where she is first seen by Sir Clement Willoughby, who repeatedly attempts to seduce Evelina (80-81). The heroine also attends Mrs. Mirvan at the Pantheon, where Lord Merton first sees her and boldly stares at her, making her uncomfortable. Thus, although Mrs. Mirvan keeps Evelina physically safe, she also passively assists the heroine's introduction to her two would-be seducers (151-52). While Mrs. Mirvan's social status grants Evelina a degree of safety, her lack of discernment will put the heroine at risk when she is no longer under Mrs. Mirvan's physical protection.

Evelina is in much more danger under Madame Duval's guardianship. When the noise of the fireworks scatters Evelina's party at Marylebone Gardens, Madame Duval fails to look after her granddaughter, and Evelina, attempting to escape unwanted advances from strange men, mistakenly asks two prostitutes for protection. She soon realizes her mistake that "I had sought protection from insult, of those who were themselves most likely to offer it!" (274). Fortunately, 
Evelina finds the rest of her party before the prostitutes do anything other than embarrass her, but for a while, the women force their company upon the Branghton party. While most of the group recognizes them as prostitutes, “[a]s to Madame Duval, she was really for some time so strangely imposed upon, that she thought they were two real fine ladies. Indeed, it is wonderful to see how easily and how frequently she is deceived" (277). Madame Duval's lack of discernment is far broader, and more dangerous, than Mrs. Mirvan's. As Evelina's chaperon, Madame Duval has a responsibility not only to protect Evelina from danger, but to recognize various threats. In failing to do so, she extends rather than curtails the danger into which Evelina has found herself. ${ }^{4}$ Mrs. Selwyn protects Evelina more effectively than either Mrs. Mirvan or Madame Duval. ${ }^{5}$ Evelina's greatest threat in Bristol Hotwells is the libertine Lord Merton, but Mrs. Selwyn repeatedly shields Evelina from him through her wit (308-11, 347-48). Mrs. Selwyn fulfills her duty to protect her charge from a would-be seducer because she is present and aware of the danger and because she possesses a valuable tool—her wit — to parry unwanted, even dangerous, attention from her charge and thus to defend her.

Unlike Evelina, Belinda's physical well-being is never in any serious danger in London. Yet, just as the chaperon must put the heroine's physical body at risk while simultaneously protecting it, she also must promote the heroine's qualities while taking care that her reputation is not sullied by becoming too public or by association with vulgar or immoral companions. Belinda experiences the risk to her reputation when she overhears herself being discussed at the masquerade: "You heard of nothing, wherever you went, but of Belinda Portman, and Belinda Portman's accomplishments. Belinda Portman, and her accomplishments, I'll swear, were as well advertised, as Packwood's razor strops" (25). Although a woman's qualities must be made known to succeed on the marriage market, too much exposure can turn her into a commodity, 
lowering her value and her chances of success. In this case, Belinda's aunt, Mrs. Stanhope, is responsible for this over-saturation, and she likewise unwisely selects as Belinda's chaperon a woman who fails to undo the risk of Belinda's overexposure on the marriage market. Mrs. Stanhope chooses Lady Delacour as a chaperon because she is fashionable, has "knowledge of the world," possesses "indisputable" wit and beauty, and "has an incomparable taste in dress" (Edgeworth 9); with Lady Delacour, Belinda will move in fashionable circles and be more likely to meet and marry a wealthy man. Belinda's aunt never considers that Lady Delacour's reputation as a coquette makes her an inappropriate chaperon. When Belinda recognizes the danger that her chaperon poses to her, she writes to her aunt, requesting "that she might not remain under the protection of a lady, whose character she could not approve, and whose intimacy might perhaps be injurious to her reputation, if not to her principles" (15). Mrs. Stanhope brushes off Belinda's concerns and declares "that her reputation [is] in no danger" and that Lady Delacour is "a perfectly fit chaperon for any young lady to appear with in public, as long as she [is] visited by the first people in town" (16). For Belinda's aunt, reputation centers on popularity rather than morality, and as long as the chaperon remains fashionable, Mrs. Stanhope mistakenly believes that Lady Delacour cannot injure Belinda's reputation.

Lady Delacour, however, should know that reputation and popularity remain tied to society's view of one's morals. The chaperon's coquettish relationship with Colonel Lawless leads to scandal and risks her reputation and her husband's, as she tells Belinda: "Wherever I went ... envy and scandal joined hands to attack me, and I heard wondering and whispering wherever I went" (45). Lady Delacour fails to protect her own reputation, which results in the dueling death of Lawless at hands of Lord Delacour. ${ }^{6}$ Although Lady Delacour feels guilty about Lawless's death, she continues to flirt with men and becomes a subject of gossip. When Lady 
Delacour shares her history with Belinda, the heroine again feels uncomfortable with having a dissipated aristocrat for a chaperon: "She trembled at the idea of being under the guidance of one, who was so little able to conduct herself; and she could not help blaming her aunt Stanhope severely, for placing her in such a perilous situation. ... Belinda, the more she reflected, the more she was surprised at her aunt's having chosen such a chaperon for a young woman just entering into the world" (69). Yet, Belinda does not repeat her request to her undiscerning aunt to leave Lady Delacour; instead, she begins making more of her own judgments and decisions, eventually choosing to stay with a woman she views as a more appropriate chaperon. When Lady Delacour becomes irrationally jealous of Belinda, the heroine takes it upon herself to protect her reputation by staying with the Percivals. Only when Lady Delacour experiences a complete reformation does she become an appropriate guardian of Belinda's reputation. ${ }^{7}$

Belinda's other chaperon, Lady Anne Percival, recognizes that although Lady Delacour is failing as a guardian, the heroine's reputation is not necessarily destined to be ruined: "Indeed,' said Lady Anne, 'miss Portman is in a dangerous situation — but some young people learn prudence by being placed in dangerous situations" (108). Here Lady Anne reveals a paradox: that a chaperon who fails as a guardian may in fact be helping her charge develop her own judgment and discernment. Yet, she carefully qualifies that this may be the case only for "some young people," rather than a general principle for all young women. After all, few heroines make as few mistakes as Belinda does, and Evelina has demonstrated the great risk a chaperon takes in placing her charge in dangerous situations, a risk that outweighs any potential benefit. Belinda's social discernment is revealed through her good decisions, and ultimately, her reputation depends upon these choices. Lady Anne never defends Belinda's reputation because she never places the heroine in a situation that endangers her reputation. Instead, she ensconces 
Belinda in a haven of domesticity away from fashionable London society. Although this protects the heroine's reputation, the shelter of domesticity poses challenges to the chaperon's other roles, as we shall see.

\section{"Blamed Herself for Not Having Better Instructed Me": The Chaperon as Mentor}

In her role as mentor, the chaperon is expected to advocate correct female behavior. Although gender ideology was in flux in Britain during the eighteenth century, prescriptive literature tended to assign gender-specific virtues and chide gender-specific vices. Anthony Fletcher argues that during the Early Modern period gender roles became more specific, and fixed so that "in Jane Austen's world of gender there was an assurance among men, and apparent acceptance among women, about the stability and security of the social roles and patterns of behaviour expected respectively of men and women" (407). In his study of eighteenth-century gender ideology, Robert Shoemaker identifies the virtues expected of women as "chastity and purity; modesty, meekness, and patience; tenderness and charity; and piety and devotion" (23). ${ }^{8}$ He notes that "female virtues were primarily concerned with qualities associated with the emotions" (24), yet female vices resulted from women's “tendency to be governed too much by their passions and too little by reason," and they included vanity, lust, impatience, high spirits, talkativeness, gossip, peevishness, caprice, and idleness (26-29). Mary Poovey comments, "Given the voraciousness that female desire was assumed to have, the surest safeguard against overindulgence was not to allow or admit to the appetites of any kind. Thus women were encouraged to display no vanity, no passion, no assertive 'self' at all” (21). Women who succeeded in fulfilling this mandate, enacted female virtues; those who demonstrated female vice were revealing some type of desire. As a mentor, the chaperon is a female authority figure; therefore, one might expect the successful fictional chaperon to fulfill female virtues and the 
failed chaperon to embody female vices. Yet the chaperons in Evelina and Belinda defy this expectation. In Burney's novel, Mrs. Mirvan, who exemplifies female virtue, and Madame Duval, who typifies female vice, both fail as chaperons, while the masculine Mrs. Selwyn succeeds. In Edgeworth's novel, both the domestic paragon Lady Anne Percival and the wayward Lady Delacour only partially succeed as chaperons. Fulfilling the standards of correct female behavior does not make a woman a good chaperon; in fact, these standards may impede rather than aid chaperoning. This in turn calls into question the value of these standards for women and opens space for dissent from eighteenth-century gender ideology.

At first glance, Mrs. Mirvan seems to be the perfect chaperon for Evelina. Lord Orville describes her as "a true feminine character" (324), and she acts as a replacement for Evelina's dead mother; Evelina refers to her as "[m]y mamma Mirvan, for she always calls me her child" (74). As Straub notes, "Mrs. Mirvan ... seem[s] formed on the conventions of female virtue recommend by writers like James Fordyce, Thomas Gisborne, and George Savile, Earl of Halifax" (57). In performing her specific duties as a mentor, however, Mrs. Mirvan's record is varied. She succeeds in making certain that Evelina and Maria are dressed appropriately for urban society, making sure that they "Londonize" themselves by purchasing "silks, caps, gauzes, and so forth" $(70,72)$, without becoming overly obsessed with dress, like Mrs. Allen in Austen's Northanger Abbey (1818). ${ }^{9}$ Yet, a chaperon must not look only after her charge's appearance, but also her behavior. London society has distinct codes and expectations of behavior which Evelina, having been raised in the country by a clergyman, is ignorant of, but Mrs. Mirvan fails to assess Evelina's ignorance of, or to prepare her for, London customs. Evelina makes multiple mistakes during her first public appearance at Mrs. Stanley's private ball: she refuses to dance with Mr. Lovel but then accepts Lord Orville's hand; she finds it impossible to make small talk 
with Orville; and she deserts him on the dance floor. Evelina looks to Mrs. Mirvan for advice and aid, but the chaperon has disappeared to play cards. Evelina later tells "Mrs. Mirvan my disasters, and she good naturedly blamed herself for not having better instructed me, but said she had taken it for granted that I must know such common customs" (79). Mrs. Mirvan lacks the discernment to aid her charge, for of course Evelina would not have learned such cultural codes at Berry Hill. Despite the chaperon's own knowledge of and performance of expected female behavior, she neglects to pass that knowledge on to her charge.

Evelina's second excursion into London society is no more successful than her first. At the ridotto, a public dance, Evelina claims to be pre-engaged to dance with Lord Orville in order to avoid dancing with the persistent Sir Clement Willoughby. Evelina's ruse backfires: when Sir Clement persists, Mrs. Mirvan “at last told me, I must either go down one dance, or avoid his importunities by returning home" (89). Not only is Evelina forced to dance with Sir Clement, but to her embarrassment, Lord Orville learns of her deception. Although Mrs. Mirvan is present, Evelina fails to behave properly at a public dance, and she is again embarrassed by her ignorance of the social customs. Because her chaperon fails to provide her with guidance and aid in these two incidents, Evelina wishes for "a book, of the laws and customs à-la-mode, presented to all young people, upon their first introduction into public society" (129). Thus, Burney, author of such a book in novel form, neatly justifies her text and suggests that a book may be the best chaperon.

Mrs. Mirvan exemplifies the paradox of the well-behaved chaperon's failure in the most significant decision in courtship narrative: in her marital choice. Captain Mirvan's coarseness and violence repeatedly embarrass his wife, his daughter, and Evelina. Upon first meeting the captain, Evelina describes him as "surly, vulgar, and disagreeable" and comments, "[T]hat kind 
and sweet-tempered woman, Mrs. Mirvan, deserved a better lot. I am amazed she would marry him" (84). Margaret Anne Doody observes that in this passage "Evelina expresses her true feelings of dislike and distrust, and a sharp sense of disappointment — not only in the brutal captain but in the woman who would marry him. Quietly, Evelina desists from claiming family relationship to the Mirvans anymore; we hear no more of 'mamma Mirvan"” (46). As Straub asserts, "Matrimony is not, for Mrs. Mirvan, a happy-ever-after reward, but a lifelong trial of her forbearance" (58). The fact that a woman who exemplifies the standard of proper female behavior can marry a vulgar man calls into question the value of fulfilling those standards.

While Mrs. Mirvan displays female virtue, Madame Duval epitomizes two female vices: bad temper and vanity. ${ }^{10}$ She displays her bad temper in the stereotypical female manner: she uses her tongue. When Madame Duval is attacked by Captain Mirvan in the guise of a highwayman, she volubly "lament[s] her case," grieving the loss of her curls, the destruction of her clothing, and the rough treatment of her body: “'I believe,' she cried, 'never nobody was so unlucky as I am!"” (191). ${ }^{11}$ Although her anger is understandable, she vents it in an unruly and ineffective manner. Madame Duval's behavior matches Richard Allestree's description of “an imperious woman": she is "a plague to her relatives, and a derision to strangers, yea and a torment to herself' $(1: 41) .{ }^{12}$ Madame Duval's loquacious ire is a monstrous female vice, and she fails to provide Evelina with a proper model of female behavior, though the timid heroine seems in no danger of adopting her vulgar grandmother's behavior.

Madame Duval also displays the female vice of vanity, which is described by conduct literature writers as the female version of improper pride. ${ }^{13}$ Her vanity is evident in her ongoing concerns about her appearance, which she manifests by dressing inappropriately for her age. One of the first things Evelina notices about her grandmother is that she "dresses very gaily [and] 
paints very high" (99). Although using cosmetics was common in the period, it was routinely rebuked in conduct literature, as the anonymous author of The Art of Governing a Wife (1747) writes: "The Woman that lays Paint upon her Face, lays on her own Infamy, and lays aside her Shame; she adds no Youth or Beauty, but wrongs her Judgment, her Age, and her Countenance. Every one who sees it, concludes she has little of her own to trust to, that has Recourse to such base borrowed Helps" (119). The use of paint aligns Madame Duval with the negative stereotype of a sexually voracious older woman.

Madame Duval's vanity contributes to the horror and the comedy of the carriage attack, which Evelina describes:

[S]o forlorn, so miserable a figure, I never before saw. Her head-dress had fallen off; her linen was torn; her negligee had not a pin left in it; her petticoats she was obliged to hold on; and her shoes were perpetually slipping off. She was covered with dirt, weeds, and filth, and her face was really horrible, for the pomatum and powder from her head, and the dust from the road, were quite pasted on her skin by her tears, which, with her rouge, made so frightful a mixture, that she hardly looked human. (190-91)

Captain Mirvan directly attacks Madame Duval's humanity by destroying her carefully created façade ("she hardly looked human" after all). But her use of pomatum, powder, and rouge - the instruments of her vanity — contributes to her monstrous, inhuman appearance in the ditch. Janice Farrar Thaddeus further points out that the "distinction between 'dirt' and 'filth' from the ditch also implies that she is covered with garbage—or even sewage—as well as mud. Her attempt to be fashionable is totally undermined. All the items she has bought and applied with such care have turned from allurements to disgusting filth" (46). ${ }^{14}$ Yet despite the horror of the 
scene, Madame Duval's extreme vanity also makes the image of her appearance in the ditch comic. When Madame Duval complains the next day about the ruin of her gown, her cap, and her wig, Evelina editorializes to Villars, "During this conversation, she endeavored to adjust her head dress, but could not at all please herself. Indeed, had I not been present, I should have thought it impossible for a woman at her time of life to be so very difficult in regard to dress. What she may have in view, I cannot imagine, but the labour of the toilette seems the chief business of her life" (197). Vanity is associated with both ego and sexual desire, and at Madame Duval's "time of life" she is not, according to eighteenth-century ideology, supposed to possess either.

Madame Duval's sexual desire becomes clear when she discovers M. Du Bois courting Evelina: "[S]he began, in French, an attack which her extreme wrath and wonderful volubility almost rendered unintelligible; yet I understood but too much, since her reproaches convinced me she had herself proposed being the object of his affection" (291). Fordyce reproaches older women for such behavior:

And now think of a decayed beauty, who in the height of her bloom, and the career of her conquests, trusted solely to that bloom. ... [S]he would fain, if possible, keep up the appearance of them still. How? By a constrained vivacity, by a juvenile dress, by that affectation of allurement and importance, which we so readily pardon to the prime of life, but which in its decline is universally condemned as aukward and unnatural. (2: 29-30)

In attempting to appear sexually desirable in order to win a third husband, Madame Duval makes herself ridiculous according to eighteenth-century standards of female behavior, and she brings censure upon herself. ${ }^{15}$ 
As already noted, Villars recognizes Madame Duval's incapacity to chaperon Evelina appropriately. When he reluctantly allows Evelina to return to London in her grandmother's care, he warns her, "You will have occasion, in the course of the month you are to pass with Madame Duval, for all the circumspection and prudence you can call to your aid: she will not, I know, propose any thing to you which she thinks wrong herself; but you must learn not only to judge but to act for yourself” (205). Although Villars expects Evelina to become like Belinda, he fails to admit Evelina's obligation to submit to Madame Duval, who is her elder, her chaperon, and her grandmother, and thus possesses authority that should, were her demands appropriate, supercede that of Villars, who is not, in fact, related consanguinally to Evelina. Instead of fulfilling female virtue, however, Madame Duval undercuts her authority by calling attention to her own social superfluity. As Doody summarizes, "Madame Duval is the focus for everything that makes female life seems hopeless or depressing; she has only 'feminine' interests (dress, parties, gossip), and she is a compound of feminine affectations. But she is also old, past her time as a sexual object, and therefore superfluous. She represents the lowering fate of womankind" (51). While fulfilling female virtues does not make Mrs. Mirvan an excellent chaperon, exemplifying female vices creates an even worse chaperon in Madame Duval.

Mrs. Selwyn contrasts Mrs. Mirvan and Madame Duval by ignoring both female virtues and vices, and acting in a more "masculine" manner. While most women in eighteenth-century Britain were identified according to their relationship with a man-Mrs. Mirvan is married, Madame Duval is a widow-Mrs. Selwyn's status is ambiguous. She is never associated with a man in the novel, and it remains unclear whether she is a widow like Madame Duval or a spinster who is given the title of "Mrs." because she has reached a certain age. Accordingly, Mrs. Selwyn occupies a space that is less controlled by patriarchy than that of her fellow 
chaperons in the novel. ${ }^{16}$ Evelina describes Mrs. Selwyn as "a lady of large fortune" (299) who lives outside the prescribed behavior for women:

Mrs. Selwyn is very kind and attentive to me. She is extremely clever; her understanding, indeed, may be called masculine; but, unfortunately, her manners deserve the same epithet; for, in studying to acquire the knowledge of the other sex, she has lost all the softness of her own. In regard to myself, however, as I have neither courage nor inclination to argue with her, I have never been personally hurt at her want of gentleness; a virtue which, nevertheless, seems so essential a part of the female character, that I find myself more awkward, and less at ease, with a woman who wants it, than I do with a man. She is not a favourite with Mr. Villars, who has often been disgusted at her unmerciful propensity to satire. (307)

Evelina's critique of Mrs. Selwyn's brusqueness reflects the eighteenth-century expectation that because men and women have different responsibilities, they should have different qualities. Allestree asserts that although "Affability and Courtesie" are "amiable in all," they are "singularly so in women of Quality, and more universally in them then in the other Sex. For men have often charges and employments which do justify, nay perhaps require somwhat of sternness and austerity; but women ordinarily have few or no occasions of it" (1:65). Fordyce sees any blurring of the distinction between men and women "monstrous." He asserts that a "masculine woman must be naturally an unamiable creature," and he adds that a woman who "throws off all the lovely softness of her nature, and emulates the daring intrepid temper of a man-how terrible!” (1: 104-05). A woman like Mrs. Selwyn, who does not fulfill eighteenth-century expectations of female behavior, is seen as unnatural. 
Mrs. Selwyn reveals her "masculinity" by her use of wit. While wit is usually praised in men — and comic heroines are often smart, witty women — conduct literature generally cautions women against wit. ${ }^{17}$ Fordyce gives a typical warning: "Wit is commonly looked upon with a suspicious eye, as a two-edged sword, from which not even the sacredness of friendship can secure. It is especially, I think, dreaded in women. . . . But when I speak on this subject, need I tell you, that men of the best sense have been usually averse to the thought of marrying a witty female?" (1: 191-92). This skepticism toward female wit is reflected in the reactions of others to Mrs. Selwyn. When Merton and Coverley request ideas for their wager, Mrs. Selwyn suggests that "'since the gentlemen are not allowed to risk their necks, suppose we decide the bet by their heads?" (325). She proposes that "the thousand pounds should fall to the share of him who can repeat by heart the longest ode of Horace" (325). While most of the company laughs at Mrs. Selwyn's suggestion, Merton and Coverley are "rather at a loss in what manner to receive this unexpected proposal” (325). Mrs. Selwyn responds, “'Come, Gentlemen, ... why do you hesitate? I am sure you cannot be afraid of a weak woman?" (325). Thus, Mrs. Selwyn reveals the male fear of female wit and acknowledges its cause: she demonstrates that she has studied and retained knowledge better than the men have.

The reaction of the men—Merton, Coverley, and Lovel—reflects Fordyce's assertion that witty women are dreaded. The foppish Lovel not surprisingly asserts that he has "an insuperable aversion to strength, either of body or mind, in a female" (393). Coverley adds that he would "as soon see a woman chop wood, as hear her chop logic" (393). Merton agrees, contending that "a woman wants nothing to recommend her but beauty and good-nature; in every thing else she is either impertinent or unnatural. For my part, deuce take me if every I wish to hear a word of sense from a woman as long as I live!" (393-94). Mrs. Selwyn's wit ultimately gets the better of 
the men when she disdainfully replies, "It has always been agreed ... that no man ought to be connected with a woman whose understanding is superior to his own. Now I very much fear, that to accommodate all this good company, according to such a rule, would be utterly impracticable unless we should chuse subjects from Swift's hospital of idiots" (394). Although Merton, Coverley, and Lovel are hardly paragons of correct masculine behavior, Evelina seems to accept their judgments of Mrs. Selwyn's wit as she writes to Villars: "How many enemies, my dear Sir, does this unbounded severity incite!" (394). As a masculine, witty woman, Mrs. Selwyn does not serve as a role model of the prescribed standard of female behavior for Evelina. Yet without the usual female virtues or the expected female vices, she serves as Evelina's most capable mentor, thus calling into question the efficacy of the eighteenth-century construction of proper femininity and the ability of such femininity to replicate itself.

Evelina's criticism of Mrs. Selwyn, while conventional, seems misplaced and occasionally petty. The heroine complains that Mrs. Selwyn "is contented with behaving well herself, and does not, with a distinguishing politeness, raise and support me with others" (329), and later Evelina claims that her chaperon is "too much engrossed in perpetual conversation to attend much to me" (331). Yet Mrs. Selwyn does listen to Evelina, and she looks after Evelina's well-being (315). Evelina also indirectly questions Mrs. Selwyn's judgment of people, for while she is not as easily fooled by people as Madame Duval, Mrs. Selwyn occasionally judges people based on their wit rather than their character. Thus Sir Clement is "a favourite with her" because he is capable of engaging in a "lively" conversation with her $(361,363)$. However, after Mrs. Selwyn overhears Sir Clement and Orville discussing Evelina in the garden, Evelina does not record any more "lively" conversations between her chaperon and Sir Clement; instead, the chaperon becomes an even stronger supporter of Orville, whom she already approved of because 
of his good manners (318). Although Evelina complains about Mrs. Selwyn, the older woman's actions do not always match Evelina's criticism, and she remains a strong mentor to and successful chaperon of Evelina. ${ }^{18}$

The chaperon's role as mentor becomes more confused in Belinda, as the heroine herself mentors as much as she is mentored. Initially Belinda's first chaperon, Lady Delacour, appears to be a suitable guide through London society: "The newspapers were full of lady Delacour's parties, and lady Delacour's dresses, and lady Delacour's bon mots: every thing, that her ladyship said, was repeated as witty; every thing, that her ladyship wore, was imitated as fashionable" (10). A woman of fashion, however, does not necessarily make a good wife and mother, as Belinda quickly discovers. Lady Delacour's home life is described as “domestic misery" (10): the Delacours bicker and jockey for power, and Lady Delacour abhors domesticity, which she refers to as "the evils of domestic life" (120). According to Thomas Gisborne in $A n$ Enquiry into the Duties of the Female Sex (1797), such domestic unhappiness was common in "fashionable families" of London: "The husband and the wife are systematically kept asunder. Separate establishments, separate sets of acquaintance, separate amusements, all conspire to render them strangers, and afterwards, indifferent, to each other. If they find themselves brought together in mixed company, to be mutually cold, inattentive, and forbidding, is politeness" (329). Lady Delacour's domestic misery seems to result from her failure to follow conduct manual advice on "managing" a husband. She tells Belinda that "I married my lord Delacour, knowing him to be a fool, and believing that, for this reason, I should find no trouble in governing him," but she underestimates her husband and discovers that "a fool, of all animals in the creation, is the most difficult to govern" (37). She disputes with Lord Delacour instead of following Gisborne's advice: "In female manners inspired by affection, and bearing at once the stamp of 
modesty and of good sense, example operates with a captivating force which few bosoms can resist. When the heart is won, the judgement is easily persuaded" $(246-47) .{ }^{19}$

Lady Delacour also fails to follow conduct manual advice regarding her maternal duties. Her first child is stillborn; her second dies after three months because Lady Delacour has difficulty breastfeeding; and her third, Helena, is sent off to boarding school and never sees her parents. Lord Delacour's aunt, Mrs. Margaret Delacour, sees Lady Delacour's neglect of her daughter as evidence that she is a "monster": "I am convinced that she hates her daughter. Why she never speaks of her—she never sees her-she never thinks of her!" (102-03). Thus, Lady Delacour's failure to value (much less succeed in) the female realms of domesticity and motherhood (much like Madame Duval's failure to follow the behavioral codes for women) makes her a poor mentor for Belinda.

Lady Delacour's behavior causes Belinda to reject whatever advice she might give. The heroine recognizes that "lady Delacour was an imprudent woman in her own conduct, and not scrupulous as to that of others. Belinda was not guided by her opinions of propriety" (138). Belinda's lack of an advisor allows her to develop her own careful and mature judgment, just as Madame Duval's guardianship of Evelina teaches her a certain degree of self-reliance: "Belinda's prudence seemed to increase with the necessity for its exertion. It was not the mercenary wily prudence of a young lady, who has been taught to think it virtue to sacrifice the attentions of her heart to the interests of her fortune - it was not the prudence of a cold and selfish, but of a modest and generous woman" (143-44). Belinda's judgment is based on her natural ability to read people accurately, as Patricia Comitini observes: "Belinda is depicted as having the ability to rationally think through others' actions, perceive what is seemingly imperceptible to others and make sober choices for herself which affect others' lives" (114). 
Belinda begins to judge for herself, and in an unusual reversal of roles, she advises Lady Delacour. As Beth Kowaleski-Wallace observes:

Belinda's position in the narrative suggests that the author intended her to learn an important moral lesson from the elegant but dissipated Lady Delacour, to whom Belinda has been sent in order to enter society. However, Belinda's persistent adherence to higher moral standards than Lady Delacour's, her very immunity to the charms of a social life surrounding her, precludes real moral growth or instruction for the heroine. Instead, Lady Delacour stands to learn a great deal from Belinda. (242)

As Belinda earns her chaperon's trust, Lady Delacour reveals her secret wound. The heroine rewards this confidence by working to improve the aristocrat's relationships with her family. Belinda reconciles Lady Delacour and her daughter, Helena, and she makes peace between Lady Delacour and her husband's aunt, Mrs. Margaret Delacour. Most important, she reconciles the Delacours to each other-first by convincing Lady Delacour to trust her husband with the secret of her wound, then by persuading Lady Delacour to allow Lord Delacour to read Hervey's letters, which terminates the husband's distrust of his wife. Finally, she fosters a relationship between the Delacours and the Percivals that will encourage both Lady and Lord Delacour to become more appreciative of and more engaged in domesticity. Ultimately, "by the end of the novel, Belinda's role approximates the author's own: at the conclusion both Belinda and the author have labored to 'shape' a rehabilitated Lady Delacour who triumphantly assumes her proper role as wife and mother" (Kowaleski-Wallace 242).

In contrast to Lady Delacour, Lady Anne Percival is a domestic "paragon" who fulfills the conduct book decrees on proper female behavior, which alienates Lady Delacour from Lady 
Anne before they even meet. When Hervey finds Lady Anne surrounded by her children, he "was so much struck with the expression of happiness in lady Anne's countenance, that he absolutely forgot to compare her beauty with lady Delacour's. . . . Whether she were handsome by the rules of art, he knew not; but he felt that she had the essential charm of beauty, the power of prepossessing the heart immediately in her favor" (98). Lady Anne demonstrates that the domestic mother can be more charming than the witty hostess. More important for Belinda, the Percivals model an ideal marriage based on love and respect:

She [Belinda] found herself [at the Percivals' Oakly-park] in the midst of a large and cheerful family, with whose domestic happiness she could not forbear to sympathize. There was an affectionate confidence, an unconstrained gayety in the house, which forcibly struck her, from its contrast with what she had seen at lady Delacour's. She perceived, that between Mr. Percival and lady Anne there was a union of interests, occupations, taste, and affection. . . . In conversation, every person expressed without constraint their wishes and opinions; and wherever these differed, reason and the general good were the standards to which they appealed. (215)

Lady Anne's personal qualities contribute directly to the happiness of her marriage: she "had, without any pedantry or ostentation, much accurate knowledge, and a taste for literature, which made her the chosen companion of her husband's understanding, as well as of his heart" (216). In the Percivals' ideal marriage, both partners actively create domestic happiness.

However, although Lady Anne possesses the virtue necessary to be a good mentor, she does not teach Belinda any morality that the heroine does not already understand. ${ }^{20}$ Comitini interprets Belinda's moral understanding as evidence of the heroine's lack of ideological 
conflict: "Belinda ... is the character who is always-already fully interpellated into middle-class domestic ideology before that ideology is established in the societal structure and narrative typology" (117). Yet despite Belinda's acceptance of domestic ideology, the novel reveals ideological conflict through the characters of Lady Delacour and Lady Anne Percival. For although Lady Delacour lacks the virtue required of a good mentor, she does succeed, as I will demonstrate in the next section, as a matchmaker, while the domestic Lady Anne does not. The Percivals' ideal marriage ironically does not qualify Lady Anne to create a happy marriage for others. Like Mrs. Mirvan, Lady Anne, the chaperon who embodies conduct manual ideology, lacks the agency to perpetuate it. Conduct literature ideology denies female agency, which complicates the reproduction of that ideology.

\section{“My First, My Only Object Is Your Happiness": The Chaperon as Matchmaker}

The final duty of the chaperon is her role as matchmaker. While domestic ideology insists that the role of wife is the natural role for a woman, it is the chaperon who must perform the work necessary to promote an appropriate and desirable match, which reveals that marriage does not happen naturally. For Evelina's chaperons matchmaking is complicated by her ambiguous status, for her father denies his paternity and her legitimacy. Lady Howard and Madame Duval attempt to force Sir John Belmont to recognize his daughter, but they fail to make any progress $(166-77,199-206)$. Mrs. Selwyn ultimately succeeds by surprising Sir John with a visit from Evelina. The heroine's resemblance to her mother convinces him of her identity, and Mrs. Selwyn also efficiently unravels the mystery of Polly Green's identity, whom Sir John mistakenly believed was his daughter (402-07. Villars reluctantly admits that Mrs. Selwyn is the best person to manage the situation: "It is true," he writes to Evelina, "that Mrs. Mirvan would conduct this affair with more delicacy than Mrs. Selwyn; yet, perhaps, to save 
time is, of all considerations the most important, since the longer this mystery is suffered to continue, the more difficult may be rendered its explanation" (370). Though Villars is perhaps overly optimistic that Mrs. Mirvan would eventually succeed despite her "delicacy," he correctly recognizes Mrs. Selwyn's ability to accomplish difficult tasks in a straightforward and timely manner. In making clear the heroine's true identity, Mrs. Selwyn has removed the major impediment for an advantageous marriage for Evelina.

Although this matchmaking obstacle is still in place while Evelina is with her first chaperon, Mrs. Mirvan nevertheless does her best to help her charge and her daughter meet and attract suitable husbands. Mrs. Mirvan ensures that Maria and Evelina are seen in fashionable places with fashionable company; however, Mrs. Mirvan does nothing to promote the match between Evelina and Orville, nor does she endorse any other possible husbands for her charge. Similarly, Madame Duval does not help Evelina make an appropriate marriage or aid her relationship with Orville. In fact, she is an active hindrance to Evelina's relationship with Orville. She introduces Evelina to her vulgar shop-keeping relatives, the Branghtons, and escorts her to the Hampstead assembly, a public dance. Evelina notes to Villars that the Branghtons are "so low-bred and vulgar, that I should be equally ashamed of such a connexion in the country, or any where" (140). In risking Evelina's social status by forcing her to socialize with her lower class cousins, Madame Duval violates prescribed behavior for a matchmaker, as she works solely for her comfort rather than for Evelina's benefit. Madame Duval's insistence on dancing at the Hampstead ball, like her inordinate attention to her appearance, indicate her desire to be on the marriage market, despite being a middle-aged, twice-widowed chaperon. Instead of focusing her attention on Evelina's courtship, Madame Duval is busy pursuing her own. ${ }^{21}$ Clearly Madame Duval has difficulty fulfilling the most basic duty of a chaperon: to promote the interests of a 
young woman in her care. Instead of attempting to fulfill Evelina's desire, Madame Duval tries to force Evelina to marry her cousin, Tom Branghton, in order to keep wealth within the family, but the marriage is repellent to Evelina: "I begged her not to pursue the subject, as, I assured her, Mr. Branghton was totally disagreeable to me: but she continued her admonitions and reflections, with her usual disregard of whatever I could answer" (282). While Mrs. Mirvan ignores matchmaking opportunities, Madame Duval pursues inappropriate ones, but both behaviors cause Evelina to suffer and fail to attain her desire.

In contrast to Mrs. Mirvan and Madame Duval, Mrs. Selwyn actively promotes what she recognizes as Evelina's appropriate desire: marriage to Orville. Evelina notes that Mrs. Selwyn “has frequently rallied me upon his Lordship's attention,- - and, alas! — upon the pleasure with which I have received it!" (358). ${ }^{22}$ Yet Mrs. Selwyn acts as Evelina's agent, quickly and rationally negotiating an appropriate marriage arrangement between Orville and Evelina's father. When Mrs. Selwyn abruptly informs Evelina of her impending marriage, the heroine is initially left feeling "[d]oubt, astonishment, and a kind of perturbation I cannot describe." In response to Evelina's surprise, Mrs. Selwyn teases her: "You may well be frightened, my dear, . . . for really there is something might terrific, in becoming, at once, the wife of the man you adore, - and a Countess!" Despite the chaperon's mocking tone, however, she has summarized her accomplishment as a matchmaker: she has successfully promoted a financially and socially advantageous and emotionally satisfying marriage for Evelina.

In Belinda the chaperon's duty as matchmaker complicates the novel's imperative to promote domesticity and the companionate marriage. Although matchmaking and domesticity seem integrally linked, the domestic paragon Lady Anne does not make a good matchmaker. Instead, it is Lady Delacour, despite her fraught marriage, who correctly recognizes whom 
Belinda should marry, and she works actively to promote that match. Lady Delacour champions Clarence Hervey as Belinda's husband, while Lady Anne encourages the heroine to marry Augustus Vincent. At the Percivals' Oakly Park home Belinda meets Mr. Percival's former ward Vincent, a handsome and outgoing Creole whose "countenance was open and friendly, and when he spoke upon any interesting subject it lighted up, and became full of fire and animation" (217). He possesses a charismatic personality: "he enjoyed the present undisturbed by any unavailing regret for the past, or troublesome solicitude about the future. All the good of life he tasted with epicurean zest; all the evils he braved with stoical indifference. The mere pleasure of existence seemed to keep him in perpetual good humour with himself and others" (218). Yet when he proposes to Belinda, she declines. Lady Anne encourages the heroine to reconsider. She refuses to accept Belinda's argument that she does not love Vincent, "for you may be mistaken in that persuasion. . . Does Mr Vincent appear to you defective in any of the qualities, which you think essential to happiness? Mr Percival has known him from the time he was a man, and can answer for his integrity and his good temper. Are not these the first points you would consider?" (241-42). Lady Anne, blind to any weaknesses in Vincent's character and convinced that Belinda must eventually fall in love with Vincent, persuades the reluctant heroine to enter into an unconventional informal engagement with Vincent that she may feel free to break at any time "till they were actually married" (345).

Lady Delacour is disappointed and concerned about Belinda's relationship with Vincent, for she believes that the heroine should marry Hervey, and she values Belinda's happiness. Lady Delacour declares to Belinda that "my first, my only object is your happiness - I respect and esteem as much as I love you" (332), and for a time she wisely focuses on determining whether or not Belinda will be happy with Vincent rather than on uniting Belinda and Hervey. To ensure 
that her charge marries a man for whom she has no reason to blush (338), Lady Delacour begins to investigate Vincent and his habits carefully. She dislikes that fact that he continues to socialize with her enemy Mrs. Luttridge, for she suspects that he gambles recklessly at her home. Hervey, at the request of Lord Delacour, looks into Vincent's habits and learns that he has lost a large portion of his fortune gambling at Mrs. Luttridge's. This discovery ends Belinda and Vincent's engagement, as Lady Delacour's suspicions prove to be more useful to the heroine than Lady Anne's efforts to unite Belinda and Vincent.

Not only does Lady Delacour read Vincent more accurately than Lady Anne does, but she also recognizes the man Belinda should marry: Clarence Hervey. Initially she does not encourage their marriage, as she intends to keep Hervey as her admirer until her imminent death, but with satisfaction, she determines that Hervey "had no immediate thoughts of matrimony; but that if he were condemned to marry; miss Portman would be his wife. As this did not interfere with her plans, lady Delacour was content” (80). Like Madame Duval, Lady Delacour fails as a chaperon by putting her own, arguably immoral, interests above those of her charge. Yet once Lady Delacour's reformation begins, she renounces her claim on Hervey:

I once did tell you, that I would not give up my claim to Clarence's adorations during my life. But I intend to live a few years longer after the amazonian operation is performed, you know. And I could not have the conscience to keep you waiting whole years. ... Therefore I give up all manner of claim to every thing-flattery! - that, of course, you will allow me from poor Clarence. (194) From this point in the novel Lady Delacour begins to take seriously the chaperon's role as matchmaker. 
Lady Delacour shares with Belinda a packet of Hervey's letters written during his travels in Dorset and Devonshire, asserting that "if ever there were letters calculated to make you fall in love with the writer of them, these are they" (272). Belinda refuses to read the letters, since Hervey has never indicated that he desires to marry her, and she will not allow herself to fall in love with a man who will not become her husband. Furthermore, Sir Phillip Baddely has informed Belinda that Hervey keeps a mistress in Windsor. Lady Delacour is surprised and disappointed at Belinda's scruples:

“Why, my dear!” said lady Delacour with a look of mingled concern, reproach, and raillery, "have you actually given up my poor Clarence, merely on account of this mistress in the wood, this Virginia St Pierre? Nonsense! Begging your pardon, my dear, the man loves you. Some entanglement, some punctilio, some doubt, some delicacy, some folly, prevents him from being just at this moment where, I confess, he ought to be-at your feet. (272-73)

While Belinda's scruples against the sexual double standard are legitimate, fortunately Hervey's "mistress" turns out to be a ward whom he attempted, but failed, to educate to be his wife. Lady Delacour, recognizing Belinda and Hervey's mutual though undeclared desire, works to effect their union, even as the two would-be lovers involve themselves with other potential spouses. Lady Delacour's efforts are rewarded when Belinda and Hervey disentangle themselves from their other relationships. She is present when Hervey finally declares to Belinda "in the most passionate terms ... that from the moment he had discovered her real character, at the masquerade at lady Singleton's, his whole soul had been hers" (471). Lady Delacour has been much more aggressive about promoting the marriage of the heroine than many chaperons in novels of the period, and her presence during Hervey's declaration of love reflects her 
importance in creating the match. Because Belinda has been so perfectly interpellated into domestic ideology, as Kowaleski-Wallace argues, she "could not have been expected to recognize the presence of her own passions. Only Lady Delacour - a former denizen of those dangerous reaches beyond the domestic sphere and associate to Harriot Freke-can possibly name the heroine's secret desire" (260). Belinda requires a chaperon who is not so domestic that she cannot recognize desire, and Lady Delacour is just the woman to fulfill that need. In making demonstrating the faultline in domestic ideology that makes desire incompatible with domesticity, Edgeworth's novel reveals the difficulty in replicating domesticity and opens space for dissent from the ideology.

Lady Delacour's involvement in Belinda and Hervey's courtship is justified because Hervey is ultimately revealed to be more moral, generous, and thoughtful than his rival, Vincent. The novel repeatedly characterizies Hervey as a man of principle; even his faults and failures, such as the fiasco with Virginia, result from his principles. When Hervey gambles, he wagers on his own skills (in driving pigs, passing as a woman, and walking) rather than on chance, like Vincent. Hervey does not allow a bet to interfere with general good breeding, choosing to lose a race by failing to "keep the path" against Sir Philip Baddely rather than run over a small child (91). After nearly drowning because of his next bet, Hervey no longer wagers in the novel. Because he bases his actions on principles, he can learn from his mistakes. ${ }^{23}$ Unlike Vincent, Hervey's ability to change and grow more virtuous makes him worthy of Belinda.

Vincent, on the other hand, is repeatedly described as a "man of feeling": "he thought that the feelings of a man of honour were to be his guide, in the first and last appeal; and for his conduct through life, as a man and as a gentleman, he proudly professed to trust to the sublime instinct of a good heart" (424). Depending on his feelings rather than his reason to guide his 
actions, Vincent lacks an accurate moral compass. His feelings lead to his addiction to gambling: "he played on ... with all the impetuosity of his natural temper; his judgment forsook him; he scarcely knew what he said or did; and, in the course of a few hours, he was worked up to such a pitch of insanity, that in one desperate moment, he betted nearly all that he was worth in the world - and lost!" (429). Financially, Vincent still may have been in the position to marry Belinda, since Hervey blackmails the cheating Mrs. Luttridge into restoring what Vincent has lost. But Vincent's impetuous duel with Sir Philip and his decision to borrow money from a Jew at an exorbitant rate complete his break from Belinda and, largely, from the Percivals as well (443-50). Unlike Hervey, Vincent repeatedly rejects attempts at reform by both Mr. Percival and Hervey, choosing to act on his feelings rather than on moral advice. ${ }^{24}$

Ultimately, the prudent heroine follows Lady Delacour's advice and marries the principled Clarence Hervey. Even Lady Anne recognizes that she mistook Vincent's character, and in "a most kind and sensible letter" to Belinda she "expressed the highest approbation of her conduct, the most friendly concern for her disappointment, and the most polite and sincere hopes, that Belinda would still continue to think of her with affection and esteem; though she had been so rash in her advice, and though her friendship had been apparently so selfish" (450). Lady Delacour comments, "I hope, Belinda, you give me credit, for having judged better of Mr Vincent than lady Anne Percival did?" (451). By accurately reading Hervey’s and Vincent's characters and Belinda's inclinations, the fashionable, flawed Lady Delacour proves to be a better matchmaker than the domestic Lady Anne. ${ }^{25}$

\section{"You All Have Wit Enough to Find It Out": The Chaperon as Ideological Dissent}

Though their experiences on the London marriage market differ, Evelina and Belinda both encounter successes and failures through their chaperons. ${ }^{26}$ Through their duties as 
guardian, mentor, and matchmaker, the chaperons in Burney's Evelina and Edgeworth's Belinda reveal faultlines in marriage and courtship ideology. Both novels create space for dissent by calling into question the efficacy of the urban marriage market, the usefulness of female standards of behavior, and the naturalness of marriage, though both novels fall short of completely disrupting any of the aspects of eighteenth-century domestic ideology. Instead both novels describe unusual, even troubling, scenes near their conclusion that are key to understanding the space for ideological dissent that the narratives create.

In Burney's novel the two old women who are forced to race near the end of the narrative present an extreme example of the typical misogynistic social attitude portrayed throughout Evelina. Merton and Coverley determine to settle a bet by each choosing a poor octogenarian woman for a footrace. Evelina describes the scene: "Though they seemed very healthy for their time of life, they yet looked so weak, so infirm, so feeble, that I could feel no sensation but that of pity at the sight. However, this was not the general sense of the company, for they no sooner came forward, than they were greeted with a laugh from every beholder, Lord Orville excepted, who looked very grave during the whole transaction" (345). When the woman racing for Coverley slips and falls, she is hurt so badly that she "declared her utter inability to make another attempt. Coverley was quite brutal; he swore at her with unmanly rage, and seemed scarce able to refrain even from striking her" (346). In this scene society treats old, infirm, poor women with disrespect, which reflects the general social attitude toward women (and the poor) in the novel and in Burney's world. As Epstein points out, "The scene in many ways renders Burney's most acute fictive representation of the fate of feminine beauty and the attention it fleetingly commands, and of the social place of women as figures for the self-aggrandizement of men. They have only use-value and counter-value in competitions between male interests" (115). 
Similarly, Doody notes, "Unlike the scene of the assault on Madame Duval, the brutality here has no pretense of appropriate punishment. The action spills over the boundary lines of comic acceptability. It adds to the disturbance within the scene that no one save Evelina and the reader seems upset for the right reasons. ... Women have no defender-so much for chivalry" (56). Without chivalry, patriarchy creates a social environment that is unbearable for women. This environment makes the chaperon's duty particularly difficult and calls into question the ideology that allows, even encourages, such mistreatment of women.

The old women race is not, however, the final scene of violence in the novel. Before the final two letters of the novel, Evelina writes about another violent event: the battle between Lovel and the monkey. Captain Mirvan brings into Mrs. Beaumont's drawing room a monkey "full dressed, and extravagantly a-la-mode," claiming to believe the monkey to be the foppish Lovel's "relation" (430). When Lovel "vented his passion by giving a furious blow to the monkey," the animal "sprung instantly upon him, and clinging round his neck, fastened his teeth to one of his ears." Mr. Lovel's response to the monkey's action is typically melodramatic: "Mr. Lovel was now a dreadful object; his face was besmeared with tears, the blood from his ear ran trickling down his cloaths, and he sunk upon the floor, crying out, 'Oh I shall die, I shall die!Oh I'm bit to death!'” (432). This scene serves two purposes at the conclusion of the novel. First, the monkey's action punishes Lovel for his previous ill treatment of Evelina, as Doody comments:

Under the cover of Mirvan's brutality and Evelina's innocence, Burney is perpetuating an antimasculinist satire. She jokingly pays off the men for their demeaning language about women, and all that stuff about 'blushing cheek.' Lovel, who had tried to make Evelina blush and had gibed at her blushes, now 
himself blushes indeed, the flowing blood external and unusually visible. This is the only such violent scene in Evelina where the object is male, and the only one of such scenes in which the victim must be felt to deserve his fate. (65)

Yet while Lovel receives public retribution for his psychological abuse of Evelina, Merton, Coverley, and Willoughby all escape penalty for their misogynistic physical, sexual, and psychological exploitation of women. Such real mistreatment of women evades redress in a patriarchal society. Second, despite the incompleteness of the male retribution, the scene creates space of dissent from the ideology that allows oppression of women to go unpunished. Even Evelina's marriage to Orville fails to erase the endemic misogynistic social violence that Captain Mirvan's monkey points to. Thaddeus notes, "The monkey scene is so prominently juxtaposed with the Reverend Villars' fervent consent to Evelina's marriage with Lord Orville that it asserts the unruliness of things" (49). While marriages at the conclusions of comedies traditionally have been read as a restoration of the social order, Evelina's marriage does not erase the novel's argument that there is something very wrong with women's place in patriarchal society. The space for dissent from patriarchal ideology remains open.

Straub notes that Evelina "is a divided text that reveals its own dividedness" (24). She further explains:

Burney's first novel rather places in opposition two different social formulations for female destiny.... While young women like Burney would have found numerous suggestions in their culture (particularly in novels) that youth ended in a love-match, a happy-ever-after ending to courtship, they would also have found a plentitude of suggestions to the contrary: assumptions that powerlessness and loss - not happiness - were the defining features of growing out of the 
conventional period of youth and sexual attractiveness. The conflict between these two ideologies leaves traces of strain in the novel, a tension that is itself ideological: the contradictions between the novels ideologies are themselves incipient critiques of both definitions of female maturity. (25)

Such contradiction, in other words, creates space for dissent from all versions of patriarchal mandates for women, though Burney does not go so far as to suggest what such dissent may look like. ${ }^{27}$ Yet I am arguing something more: that the ideological contradictions that the novel exposes threaten the perpetuation of patriarchy. Fulfilling feminine ideals of behavior does not protect women like Mrs. Mirvan or Evelina from mistreatment by men, nor does it necessarily help perpetuate patriarchal marriage ideology. For the novel demonstrates that the woman who succeeds in promoting ideology-fulfilling marriage is Mrs. Selwyn, whose "masculine" qualities of knowledge, wit, and directness call into question why women are expected to behave in a manner that does not entirely aid them nor patriarchy. Tellingly, the chaperons and their contributions to Evelina's courtship are nearly forgotten as the conclusion unites Evelina, Orville, and Villars. ${ }^{28}$ In an attempt to suture over the ruptures in ideology and practice that she has revealed, the chaperon is all but erased from the novel's conclusion.

The chaperons in Belinda also reveal ideological contradictions, for the chaperon's success is partially divorced from her morality, as Lady Anne Percival and Lady Delacour have shown. Because Belinda and Hervey accept the domestic model portrayed by the Percivals as the ideal form of marriage, Belinda has often been read as defense of domesticity. However, such a reading has been perpetually frustrated by the odd conclusion of the novel, in which Lady Delacour self-consciously "finish[es] the novel for you," not with the traditional marriage, but by creating a tableau with the major players "in proper attitudes for stage effect" (477-78). Belinda 
and Hervey seem forced together by Lady Delacour more quickly than Belinda, at least, finds comfortable: "Clarence, you have a right to Belinda's hand, and may kiss it too. Nay, miss Portman, it is the rule of the stage." Lady Delacour concludes with the entrance of her husband and daughter, who make the picture "quite pretty and natural!" (478). Of course, this picture is not natural but self-consciously artificial; yet Lady Delacour completes the tableau by emphasizing her own newly discovered domestic happiness, along with a moral that purportedly does not need to be stated, since "[y]ou all have wit enough to find it out" (478). The very selfconsciousness of this scene opens it to various kinds of deconstruction. Alison Harvey analyzes the scene's awkwardness:

The fact that Lady Delacour has to arrange all the now-presumably-happy couples in positions which even they do not seem to find entirely comfortable reveals the uncertainties within the narrative that leads to this scene. . . Lady Delacour's direction to Belinda to give her hand to Clarence contains the hint of Belinda's reluctance to do so, and Lady Delacour's own assertion that 'what signifies being happy, unless we appear so?' undermines the putative moral of the novel: that appearances are not what are most important to happiness. $(4)^{29}$

With its awkward self-consciousness the closing scene of Belinda clearly points to ideological conflict that it simultaneously attempts to efface. Instead of erasing all the chaperons, as the conclusion of Burney's novel attempts to do, this ending emphasizes the importance of Lady Delacour, the faulty chaperon, while erasing the domestic Lady Anne, thus calling into question the power of domestic ideology.

Although Belinda appears to advocate domesticity, ideological conflict is plentiful in the novel's description of the home. ${ }^{30}$ Julie Nash notes that for Edgeworth "the English home" is "a 
site for rebellion and resolution" (163). ${ }^{31}$ The descriptions of Belinda's two chaperons and their domestic lives reveal ideological unease. Many critics have noted Lady Delacour's importance to Edgeworth's novel, and her character is an important site for dissent from domestic ideology. Katherine Montwieler argues that Lady Delacour, rather than Belinda, is the true focus of the novel: "[I]t is this paradoxical literary creation [Lady Delacour], who variously professes and critiques conventionally feminine ways of acting, who is at the center of Edgeworth's novel, which itself questions the eighteenth-century cultural and literary phenomenon of sensibility through the concomitant vehicle of the masquerade" (347-48). She explains that "Lady Delacour's apparent transformation from dissipated coquette to loving mother exposes the performative aspect at the center of the construction of late eighteenth-century femininity" (348). Rather than defending domesticity, Lady's Delacour's reformation demonstrates the performative nature of all versions of femininity, calling into question the "naturalness" of domestic ideology. Kowaleski-Wallace notes: "that Belinda's character fails to achieve its fullest dimensions attests, finally, to the demands of the domestic ideology which has been imposed upon the novel" (260). The fact that Belinda cannot complete courtship narrative without Lady Delacour's intervention, points to a faultline, and a space for dissent, from domestic ideology. ${ }^{32}$

Even those paragons of domesticity, the Percivals, reveal a faultline in the ideology. As Kowaleski-Wallace points out, the novel's depiction of domestic harmony in the Percival household "constitutes the polemic center of the novel. It is the purpose of the novel to insist on the 'naturalness' of this representation, and through Belinda's progress towards this model, the novel will explicitly sanction this vision" (246). However, the novel's depiction of the Percival family also calls into question the "naturalness" of the ideology. After a lengthy description of the Percivals in the second volume, the narrator addresses readers who may find such domestic 
happiness implausible: "Those who unfortunately have never enjoyed domestic happiness, such as we have just described, will perhaps suppose the picture to be visionary and romantic; there are others - it is hoped many others - who will feel that it is drawn from truth and real life. Tastes that have been vitiated by the stimulus of dissipation might, perhaps, think these simple pleasures insipid" (216). Kowaleski-Wallace notes that this aside points to a paradox of domestic ideology: "while the Percivals embody the most appealing mode of human existence, which the unvitiated would 'naturally' choose, the taste for such pleasure can be corrupted: such taste for domestic pleasures - though natural — must be taught to those who fail to recognize them" (246). More important, however, she contends that the novel's argument for the reality of domesticity depends upon an erasure of dissent:

In the numerous celebratory descriptions of the Percival family, the narrator must never give rise to the suspicion that another equally compelling mode of human life —one with equally "natural" claims to the human heart—might exist beyond the parameters of the domestic sphere. The ascendency of the ideal new-style patriarchal family depends, in other words, on the important negation or absence of all other competing modes of social life. (246)

Ultimately the novel neither fully embraces ideological dissent nor entirely succeeds in erasing such dissent; domesticity seemingly continues with the union of Belinda Portman and Clarence Hervey, but it cannot perpetuate itself without the aid of the domestically ambivalent Lady Delacour.

The chaperons in both Evelina and Belinda reveal a series of ideological faultines in courtship ideology: the work of the chaperon puts the heroine and her reputation at risk and simultaneously must protect her from danger; the chaperon who fulfills female domestic virtues 
is less successful than the chaperon who rejects some of the standards of proper female behavior; and the work the chaperon must do reveals that marriage (and by extension domestic ideology) is not as "natural" as the ideology insists. Since courtship requires the aid of a woman who is not fully interpellated by domestic ideology, the successful chaperon calls into question such ideology, demonstrating that proper femininity alone fails to perpetuate itself. As patriarchy depends both upon a denial of female desire and the proper channeling of that desire into marriage, the effective chaperon is vital to the continuation of patriarchal domesticity. Alan Sinfield describes a "woman's transition from daughter to wife" as "an insecure moment in patriarchy" (42-43), but in Evelina and Belinda such insecurity is not erased by the marriages that conclude the novels. Instead, the ideological chaos remains present through the disruptive violence at the end of Burney's novel and the artificial tableau created at the conclusion of Edgeworth's novel. This chaos results in part because the chaperons and the novels reveal-and cannot contain - the work required of courtship and domesticity. By revealing that courtship and marriage require work, Burney's and Edgeworth's novels call into question the ideology that underpins this social institution in the late eighteenth and early nineteenth centuries. In order to perpetuate itself, domestic ideology needs women who do not entirely adhere to its ideals even while the narratives negate these women (Evelina criticizes Mrs. Selwyn's “masculinity,” and Belinda "reforms" Lady Delacour). These women allow the fiction of the necessity and naturalness of gender and domestic ideology, just as they allow the heroine the fiction of a properly feminine lack of desire. As Mrs. Selwyn and Lady Delacour work to fulfill the negated desires of Evelina and Belinda, they also create space for dissent from marriage ideology by revealing its contradictions. Although Burney and Edgeworth seem to remain invested in the dominant ideology and therefore do not pursue these contradictions, neither do they fully erase 
them, leaving the space open for subsequent women to make more overtly dissident arguments against patriarchy.

${ }^{1}$ The chaperon of this period is thus different from both the Victorian chaperon, who directly supervises a courting couple, and the Spanish duenna, whose task is to guard a young woman's heart and, more important, her virginity until her parents arrange her marriage. In fact, in the novels of the period at least, young women visiting London are left on the dance floor while the chaperon plays cards in another room, and the young women also meet with male callers, though not necessarily suitors, alone for short visits while their chaperon is away from home. Eighteenth-century British notions of a chaperon's duty collide with the role of the Spanish duenna in Sheridan's comedy The Duenna, in which the overarching joke is that the title character rejects her duty. Instead of ensuring Louisa's marriage to Isaac, her father's choice whom the heroine does not desire, the duenna tricks Isaac into marrying her instead, and she helps Louisa marry Antonio, the man she loves. Thus, Sheridan's duenna refuses to perform her assigned duty but fulfills the ideology of marriage for love, which had become more popular in England over the course of the eighteenth century.

${ }^{2}$ The risk of entrusting one's daughter to a disastrous chaperon leads Thomas Gisborne, in his book An Enquiry into the Duties of the Female Sex (1797), to advise mothers against sending their daughters to the city with a chaperon but to accompany them themselves: "Let her [your daughter] not be abandoned in her outset in life to the giddiness and mistaken kindness of fashionable acquaintance in the metro polis; nor forwarded under their convoy to public places, there to be whirled, far from maternal care and admonition, in the circle of levity and folly" (97).

${ }^{3}$ Perry views the fictional aunt figure as peripheral:

Like a fairy godmother with a sharp wit, she seems to exist for the sake of the orphaned young woman whom she protects and advises. She rarely has any other narrative function or any story of her own; if she were removed from the text the story line would not be altered - except that the ingénue heroine would stumble more hesitatingly through the world without this older woman's understanding of life to supplement her inexperience. In a sense, her presence confirms the innocence of the heroine. (348)

For Perry, the aunt is incidental to the plot. I, on the other hand, am arguing that a specific kind of aunt, the chaperon, is vital to courtship narrative.

${ }^{4}$ Earlier at the opera house Madame Duval and the Branghtons embarrass Evelina, so she rashly decides to go with Sir Clement in search of the Mirvans, who have already returned home. She is then forced to accept a carriage ride with Sir Clement to the Mirvans' house, and during the ride Sir Clement attempts to seduce Evelina (140-46). Although Mrs. Mirvan is responsible for Evelina's acquaintance with Sir Clement, Madame Duval has failed to ensure that Evelina is not placed in an embarrassing situation. 
${ }^{5}$ Kristina Straub asserts that because Mrs. Selwyn is "[s]een as powerless, she is actually so" (27). However, in her analysis Straub overlooks Mrs. Selwyn's repeatedly successful actions as a chaperon.

${ }^{6}$ Lady Delacour has failed to follow Lord Halifax's advice in The Ladies New Year's Gift; or Advice to a Daughter (1688) that "nothing is with more care to be avoided, than such a kind of Civility as may be mistaken for Invitation; and it will not be enough for you to keep yourself free from any criminal Engagements; for if you do that which either raiseth Hopes or createth Discourse, ther is a Spot thrown upon your Good Name" (99-100). When Gisborne describes a flirtatious wife, he writes: "Is the wife then innocent? Unquestionably not. ... She has wounded the feelings of her husband; she has exposed to risk the warmth of his affection; she has laid herself open to the insinuations of calumny; she has exhibited a dangerous example; she has hazarded her own happiness, and that of the person most dear to her, by a neglect of Discretion" (261).

${ }^{7}$ When Belinda's fiancé Augustus Vincent receives an anonymous letter that aims to destroy her reputation by making specious claims against both Belinda and her chaperon, Lady Delacour at last actively defends Belinda's character: "[I]nstantly, the whole energy of her mind, and fire of her eloquence, burst forth in an eulogium upon her friend. Careless of all that concerned herself, she explained, without a moment's hesitation, every thing that could exalt Belinda" (335). Lady Delacour admits her own failings to Vincent as she fully exculpates Belinda. She finally fulfills her role as guardian.

${ }^{8}$ In his Sermons to Young Women (1766) James Fordyce describes the feminine ideal:

They [women] were manifestly intended to be the mothers and formers of a rational and immortal offspring; to be a kind of softer companions, who, by nameless delightful sympathies and endearments, might improve our pleasures and soothe our pains; to lighten the load of domestic cares, and thereby leave us more at leisure for rougher labors, or severer studies; and finally, to spread a certain grace and embellishment over human life. (1:208)

${ }^{9}$ In describing Mrs. Allen, the narrator of Northanger Abbey notes: "Dress was her passion. She had a most harmless delight in being fine; and our heroine's [Catherine Morland's] entrée into life could not take place till after three or four days had been spent in learning what was mostly worn, and her chaperon was provided with a dress of the newest fashion" (20). However, Mrs. Mirvan is aware of the social ramifications of dress, as she attends the Drury-Lane theatre before Londonizing their dress, under the condition that they "sit in some obscure place, that she may not be seen" (70-71).

${ }^{10}$ Before the reader even meets Madame Duval, Rev. Villars informs us that she is ill-tempered, as well as ignorant and immoral, and thus unfit to chaperon Evelina: "Madame Duval is by no means a proper companion or guardian for a young woman: she is at once uneducated and unprincipled; ungentle in her temper, and unamiable in her manners" (59). Given Madame Duval's behavior as Evelina's chaperon, Villars words are prophetic. When Madame Duval 
pushes for custody of Evelina later, Villars repeats his objections: she is "the slave of unruly and illiberal passions" (172).

${ }^{11} \mathrm{Cf}$. During one of Evelina's early visits to Madame Duval, the older woman "began, with great bitterness, to inveigh against the barbarous brutality of that fellow the Captain, and the horrible ill-breeding of the English in general, declaring she should make her escape with all expedition from so beastly a nation" (112).

${ }^{12}$ Allestree adds that when women become angry, "they render themselves at once despised and abhor'd; nothing being more ridiculously hateful, then an impotent rage" (1: 43-44). He further continues, "The barking of a dog, tho we are secure he cannot bite, is a grating unplesant sound; and while women seek that way to vent their rage, they are but a sort of speaking brutes, and should consider whether that do not reflect more contempt upon themselves, then their most virulent reproaches can fix upon others" (1:44).

${ }^{13}$ Hester Chapone explicates in Letters on the Improvement of the Mind (1773): "As women are more fearful than men, perhaps this may be one reason why they are more vain than proud; whilst the other sex are oftener proud than vain. . . Whilst men are proud of power, of wealth, dignity, learning, or abilities, young women are usually ambitious of nothing more than to be admired for their persons, their dress, or their most trivial accomplishments" (61-62).

${ }^{14}$ See also Julia Epstein, who notes, "It is not primarily physical injury that is here sustained, though the physical attack is severe enough, but the violation of appearance" (87).

${ }^{15}$ Madame Duval works to look younger and more marriageable, and she refuses to act her age. Restrictions for older women and widows pervade prescriptive literature of the period. Allestree recommends that a widow "put on a more retir'd temper of mind, a more strict and severe behavior. . . . Indeed that State as it requires a great sobriety and piety, so it affords many advantages towards it. ... She has her time and her fortune at her own command, and consequently may much more abound in the works both of Piety and Charity" (2: 75). In Strictures on the Modern System of Female Education (1799) Hannah More describes the result of a woman's failure to become sober as she ages:

Since then there is a season when the youthful must cease to be young, and the beautiful to excite admiration; to grow old gracefully is perhaps one of the rarest and most valuable arts which can be taught to woman. It is for this sober season of life that education should lay up its rich resources. However disregarded they may hitherto have been, they will be wanted now. When admirers fall away, and flatterers become mute, the mind will be driven to retire into itself, and if it find no entertainment at home, it will be driven back again upon the world with increased force. (1: 59-60)

Madame Duval epitomizes a woman who lacks the means to entertain herself, and so she fills her days with little beyond a myriad of London entertainments: opera, theatre, pleasure gardens, a museum, and even dancing.

At the Hampstead ball Madame Duval insists on dancing the minuet, much to Evelina's embarrassment: "During this minuet, how much did I rejoice in being surrounded only with 
strangers! She danced in a style so uncommon; her age, her showy dress, and an unusual quantity of rouge, drew upon her the eyes, and, I fear, the derision of the whole company" (263). As Straub notes, Madame Duval is "not only wishing to participate in an activity traditionally associated with young people and the rites of courtship, but wanting to display herself in a particularly conspicuous manner by dancing a minuet" (31). The "derision" of the other people at the ball reflects Lord Halifax's comments about proper behavior for older women. He advises his daughter to "let every seven years make some alteration in you towards the Graver side, and not be like the Girls of Fifty, who resolve to be always Young, what ever Time with his Iron Teeth hath determined to the contrary. Unnatural things carry a Deformity in them never to be Disguised; the Liveliness of Youth in a riper Age, looketh like a new patch upon an old Gown; so that a Gay Matron, a cheerful old Fool may be reasonably put into the List of the Tamer kind of Monsters" (114-15). Madame Duval's dancing makes her monstrous, while Evelina displays the sober behavior that her grandmother should have exhibited. Evelina refuses to dance at the ball, and she attempts to adopt a demeanor that will inhibit offers to dance. She writes to Villars, "I am sure, my dear Sir, you would have laughed had you seen how proudly grave I appeared" (264). In a reversal of the norm, because her chaperon acts like a giddy young woman, Evelina takes on the role of the "grave" older woman who does not dance.

${ }^{16}$ As Perry notes in her analysis of Mrs. Selwyn, "Perceptive and articulate, deracinated from any family grouping and representing independent female intelligence, she is able to take care of herself and to shield the motherless heroine from the threats posed by the patriarchal world" (356).

${ }^{17}$ According to the OED, a number of definitions of the word "wit" were in use in Burney's time. Wit could refer to, among other definitions, the mind or one of its functions; to " $[\mathrm{t}] \mathrm{he}$ faculty of thinking and reasoning in general"; to the person doing the thinking and reasoning; to "intellectual ability; genius, talent, cleverness"; to "ingenuity, skill"; to "[w]isdom, good judgement, discretion, prudence"; to "[q]uickness of intellect or liveliness of fancy, with capacity of apt expression; talent for saying [or writing] brilliant or sparkling things, esp. in an amusing way"; to "[a] witty saying or story"; to "[a] person of lively fancy, who has the faculty to saying smart or brilliant things. .. ; a witty person" ("Wit"). When Evelina refers to Mrs. Selwyn's wit, she invokes at times the meaning of "intellectual ability," and at other times Evelina refers to Mrs. Selwyn's "talent for saying brilliant or sparkling things." Evelina finds Mrs. Selwyn's wit to be self-absorbed and not what Pope refers to as "true wit" in An Essay on Criticism:

True wit is Nature to Advantage drest,

What oft was Though, but Ne'er so well Exprest,

Something, whose Truth convinc'd at Sight we find,

That gives us back the Image of our Mind:

As Shades more sweetly recommend the Light,

So modest Plainness sets off sprightly Wit:

For Works may have more Wit than does 'em good,

As Bodies perish through Excess of Blood. (297-304)

Evelina seems to think that Mrs. Selwyn's mind has an excess of wit that makes her less feminine. 
${ }^{18}$ Helen Cooper describes Mrs. Selwyn as Evelina's "briefest but arguably most effective mentor" (116).

${ }^{19}$ Likewise, Halifax asserts that "by a wise and dexterous Conduct, it will be in your power to relieve your self from anything that looketh like a disadvantage" in marriage (32). He proceeds to give specific advice for "how to cure your Husband's Mistakes" (33), such as infidelity, drunkenness, bad temper, ill humor, avarice, and stupidity. Halifax repeatedly advocates wifely submission to convince the husband to treat his wife better.

${ }^{20}$ As Comitini points out, "Belinda's intuitive knowledge about virtue takes its shape in the forms of domestic ideology represented by the Percivals, but she possesses this knowledge even before its example emerges in the narrative" (116-17).

${ }^{21}$ Her aim to marry Du Bois defies the recommendation in conduct literature that widows be cautious about remarriage: "Marriage is so great an adventure, that once seems enough for the whole life: for whether they have bin prosperous or adverse in the first, it do's almost discourage a second attempt" (Allestree 2: 80). Madame Duval has already ignored this advice by marrying Duval, and in contemplating a third marriage, demonstrates her impropriety and vanity.

${ }^{22}$ As John Zomchick notes, "Mrs. Selwyn ... forces Evelina to acknowledge her own sexual nature by denying her the pleasure of maternal protection [that Mrs. Mirvan has offered] and by 'rallying' her about Lord Orville" (361).

${ }^{23}$ Similarly, Hervey responds appropriately to Dr. X's mentoring, which "produces almost instantaneous effects in Hervey. From this point forward, he forsakes the follies of his youth and begins to assume the until-then vacant role of the hero of the tale" (Mason 279).

${ }^{24}$ The difference between Hervey's and Vincent's characters can be seen clearly through their reactions toward one another. Vincent repeatedly displays jealousy of Hervey, though not without reason. Hervey, on the other hand, demonstrates his true regard for Belinda by working to save Vincent from gambling and suicide:

Clarence's love was not of that selfish sort, which the moment that it is deprived of home, sinks to indifference, or is converted into hatred. Belinda could not be his; but, in the midst of the bitterest regret, he was supported by the consciousness of his own honour and generosity: he felt a noble species of delight, in the prospect of promoting the happiness of the woman, upon whom his fondest affections had been fixed; and he rejoiced to feel, that he had sufficient magnanimity to save a rival from ruin. He was even determined to make that rival his friend, notwithstanding the prepossession which, he clearly perceived Mr Vincent felt against him. (420)

Hervey bases his actions upon the principles of selfless regard, honor, and generosity, rather than upon selfish feelings of love for Belinda. In contrast, when Hervey prevents Vincent from committing suicide, Vincent reacts according to his feelings of jealousy and embarrassment, insisting that Hervey is his enemy. When Hervey demands, "Use your reason," Vincent responds, "I cannot ... ; I know not what to think; I am not master of myself" (432). As Lady 
Delacour notes, Vincent "is one of those men, who require great emotions. Fine lovers these make for stage effect! — but the worst husbands in the world!” (451).

${ }^{25}$ Marjorie Lightfoot notes this seeming paradox: "It is well-meaning, morally equivocal Lady Delacour, who rashly applies common sense to assist her friends and is helped absurdly by chance to resolve their problems. The author burlesques novels, plays, and fairy tales that provide artificial happy endings by means of marriage, and those that glamorize long-suffering sentimental heroines" (121).

${ }^{26}$ Colin and Jo Atkinson have also noted striking similarities and distinct differences between Evelina and Belinda: "Belinda is of the lineage of Evelina. Indeed, Belinda, who is eighteen in 1800 , could be the daughter of Evelina, who was seventeen in 1778. Both girls are country raised and lack fortune and parents, though their guardians have some connections. Both are entrusted to the care of a married lady who will introduce them into the social world of London" (97). Yet the two young women are also dissimilar: "The heroines differ: Evelina is both ignorant and naïve; Belinda is neither. . . Belinda is not only fortified with self-assurance and a better education, but she also enters a far less threatening world" (97).

${ }^{27}$ Straub comments: "The novel does not subvert social formations that define female power or its lack in terms of women's relationship to men, but it does throw these formations into disturbing juxtaposition and suggests, in the most embryonic and incompletely expressed terms, that female power would be more reliably grounded in human relationships that were less lopsided, that gave precedence to women as well as to men" (26). She further points out that in Evelina there are "jarring contractions between Burney's two ideologically determined perspectives on marriage - as both the means of escape from female maturity's hardships and as an institution that formalizes and justifies those hardships" (54).

${ }^{28}$ All three of Evelina's chaperons disappear from the conclusion of the novel. Mrs. Mirvan does not accompany her husband and daughter to see Evelina at Bristol Hotwells. Madame Duval writes only to inform Evelina that in light of her marriage to a lord she has been restored as her grandmother's sole heir. Evelina briefly mentions that Mrs. Selwyn "will be present at the ceremony" uniting her to Orville (435).

${ }^{29}$ Susan C. Greenfield notes that Lady Delacour's comment that her arrangement is "pretty and natural" "highlights the artificiality of the moment, which must be staged to seem "natural," and she suggests that " $[\mathrm{w}]$ hen Lady Delacour claims to 'finish the novel' . . ., character and author merge in a play on performance implying that perhaps neither of them trusts the final 'pretty' picture" (224). Katherine Sobba Green finds the tableau slightly less ideologically problematic: "In this highly self-reflexive scene, Edgeworth affirms what her text has repeatedly suggested through framed representations and refractions of negative exempla - that the most desirable role for woman is a domestic one, a partnership within companionate marriage. Yet, at the same time, the fact that Edgeworth chooses to have Lady Delacour arrange the scene serves as her acknowledgement that even in fiction the domestic tableau ('being happy') is achieved with difficulty" (151). 
${ }^{30}$ Critics have also found ideological faultines in Belinda in the portrayal of race and colonialism, the character of Harriet Freke, or both. See Colin and Jo Atkinson, "Maria Edgeworth, Belinda, and Women's Rights"; Andrew McCann, "Conjugal Love and the Enlightenment Subject: The Colonial Context of Non-Identity in Maria Edgeworth's Belinda"; Susan Greenfield, "Abroad and at Home': Sexual Ambiguity, Miscegenation, and Colonial Boundaries in Edgeworth's Belinda"; Alison Harvey, "West Indian Obeah and English 'Obee': Race, Femininity, and Questions of Colonial Consolidation in Maria Edgeworth's Belinda"; and Deborah Weiss, "The Extraordinary Ordinary Belinda: Maria Edgeworth's Female Philosopher."

${ }^{31}$ Unlike many courtship narratives, rebellion is found not in the young heroine but in her chaperons. In fact, as Kowaleski-Wallace points out, Belinda seems perfectly formed for a didactic tale: "Belinda seems condemned to her very tameness by the didactic purpose of the novel, a purpose which demands her unyielding perfection. Indeed, one of the novel's major flaws is the complacency of the main character, for such complacency leaves little room for tension. Belinda undergoes very little self-scrutiny or self-exploration" (242). While Evelina's inexperience leads her to awkward, even dangerous situations and thus in need of a chaperon, Belinda does nothing to propel the plot of her story, other than delay admitting that she loves Hervey; she needs a chaperon primarily to work as a matchmaker rather than to serve as a mentor or guardian. Marjorie Lightfoot points out that Belinda as a heroine does little to effect the outcome of the novel: "Admittedly, good-hearted Belinda is stiff as a heroine when behaving conventionally, which attests to the author's striking satirical outlook, for such idealization does not make Belinda effective in securing her own domestic happiness" (130). Fulfilling the version of femininity proscribed by domestic ideology does not help Belinda succeed on her own in courtship, and thus, she requires the aid of the ambivalently domestic Lady Delacour.

${ }^{32}$ See Kowaleski-Wallace, who argues that Lady Delacour's fraught relationship with domesticity points out the tension within the ideology:

Lady Delacour's narrative records the process of internalizing a specific image of womanhood, and it registers the sense of maternal guilt and obligation which was to be a necessary component of that process. En route, the novel insists upon the inevitable appeal, indeed the very "naturalness," of a particular domestic arrangement in which supreme satisfaction is to be garnered from the intimate relationship of a biological mother to her children. In order to accomplish this purpose, however, the narrative must also deny important female desires which thwart the kind of female selflessness necessary to the performance of the maternal function and which threaten the economic management of the separate spheres. (243)

Rather than being a natural version of femininity for Lady Delacour, domesticity requires that she deny her desires and focus on her daughter. 


\section{Chapter 2}

\section{"This Formidable Mother-in-Law": Marriage Ideology, the Mother-in-Law, and Dissent in Cecilia and Sense and Sensibility}

Mothers-in-law are noticeably absent from late eighteenth- and early nineteenth-century courtship novels, as are mothers in general. This absence reveals three anxieties about women in the ideology of courtship narrative: the fear of maternal power overpowering patriarchal imperatives within the narrative; the concern that older women, and specifically mothers-in-law, will distract — and interrupt — courtship narrative; and the fear of incest within the conjugal family, as the mother-in-law will develop a too-close relationship with the in-law child, making the marriage quasi-incestuous. Although many in the period believed "that marriage and motherhood would tame an otherwise unmanageable woman and make her more feminine" (Todd 114), the authority that came with motherhood (and correspondingly, with the status of the mother-in-law, who was a mother as well) posed a challenge to patriarchy. According to Nancy Armstrong, the domestic woman had "authority over the household, leisure time, courtship procedures, and kinship relations, and under her jurisdiction the most basic qualities of human identity were supposed to develop" (3). This maternal authority was not expected to last. A son would leave home at an early age to go to boarding school or to be apprenticed in a trade or craft, which would separate him from the authority of his mother. When a daughter married, she traded the authority of her parents for that of her husband. However, the mother-in-law challenged the prerogatives of both patriarchy and the conjugal family by wielding her authority over adult children. Her presence in courtship novels threatens the independence of the heroine and hero to make their own courtship and marital decisions. 
Mothers (as potential mothers-in-law) can be such strong characters that they might overpower children, especially daughters, in the children's narratives: “The absence of mothers $\ldots$ derive[s] not from the impotence or unimportance of mothers, but from the almost excessive power of motherhood; the good, supportive mother is potentially so powerful a figure as to prevent her daughter's trials from occurring, to shield her from the process of maturation, and thus to disrupt the focus and equilibrium of the novel" (MacDonald 58). When mothers-in-law are present in eighteenth-century literature, their role as mother-in-law is often suppressed to keep the focus on the young female protagonist. In Burney's Evelina, for example, both Lady Howard and Madam Duval are mothers-in-law, but they are separated from their sons-in-lawthe crass Captain Mirvan and the deadbeat dad Sir John Belmont—and therefore are not seen in the act of being mothers-in-law. Lady Howard is rarely seen with Captain Mirvan, and Madam Duval is an almost spectral mother-in-who continually threatens to meet with John Belmont but never does. Moreover, their roles as mothers-in-law are obscured by their roles in Evelina's courtship and paternal search narrative, in which they serve frequently as obstacles. Thus as mothers-in-law they are suppressed in part to allow the younger generation to have the spotlight, and ultimately, agency within courtship.

A similar suppression occurs when the mother-in-law develops too close a relationship with her daughter-in-law, risking the development of emotional incest within the conjugal family. This threat becomes literal in Daniel Defoe's Moll Flanders (1722) when the heroine discovers that her husband's mother is also her biological mother, a relationship that Moll deems "Unnatural in the highest degree in the World" (140). Yet the threat of incest that the mother-inlaw embodies is usually metaphorical and more subtle. For example, Samuel Richardson's novel Pamela (1740) begins just after the death of the eponymous heroine's mistress, Lady B. Lady B 
had mothered Pamela by favoring her and teaching her skills above those usually possessed by servants, such as singing, dancing, and needlework: Pamela's father notes in a letter to her that Lady B "gave you Learning, and for Three Years past has always been giving you Cloaths and Linen” (Richardson 13), and later Pamela states that Lady B “spar'd no Pains nor cost to improve me" (288). Because Lady B became a mother figure to Pamela, Mr B and Pamela risk emotional incest if his mother lives. When Lady B dies, her last words command that Mr B “[r]emember my poor Pamela!” (11). In making this demand, Lady B treats Pamela as a daughter who must be cared for by the patriarch of the family. However, Mr B and Pamela interpret Lady B's dying wish differently. When Pamela resists Mr B's seduction, he asks, "Why, Sauce-box, ... did not my good Mother desire me to take care of you? and have you not been always distinguish'd by me, above a common Servant? and does your Ingratitude upbraid me for this?" But Pamela insists, “[M]y good Lady did not desire your Care to extend to the Summer-house and her Dressing-room" (59). Mr B views Pamela merely as a pretty servant girl whom his mother passed on to him as the patriarch, while Pamela sees him both as her master and as the son of the woman who served as a surrogate mother to her. Had she married Mr B while Lady B was alive, Pamela would have found herself enacting a kind of emotional incest. Instead, Lady B's absence removes this threat, allowing the formation of a new conjugal family. In her book Novel Relations Ruth Perry argues that courtship novels of the period reflect a paradigm shift in the cultural concept of kinship from the consanguineal to the conjugal family: "The story is in the details of which family connections were reinforced and which were eroded as major social and economic changes transformed late eighteenth-century English society" (4). The mother-in-law is one family member who was quietly erased in this paradigm shift. 
In this chapter I argue that just as the mother-in-law is absent from courtship novels for ideological reasons, so does her rare presence serve important ideological functions in the narrative. She affects the portrayal of marriage in the novel, and her representation reflects the paradigm shift in courtship ideology during the period. She potentially disrupts the patriarchal prerogative of fathers and husbands(-to-be) to control courtship and marriage. This disruption offers space for dissent from marriage ideology by representing potential non-patriarchal authority and by revealing faultlines in marriage ideology. Mothers-in-law were expected both to support patriarchy (as represented by fathers or by inherited wealth) and to promote the happiness of their children. These responsibilities often contradicted each other, and mothers-inlaw negotiated this faultline in a variety of ways. In this chapter, I examine how the mothers-inlaw and future mothers-in-law depicted in Frances Burney's Cecilia (1782) and Jane Austen's Sense and Sensibility (1811) call into question courtship and marriage ideologies by revealing the faultline. In Cecilia Mrs. Delvile is caught in the conflict caused by the ideological paradigms of her husband, who subscribes to the old marriage ideology that parents (namely, fathers) should choose their children's spouses, and of her son, who wants to marry for love the woman of his choosing. Both ideologies grant patriarchs (old men or young men, but not women) the authority in courtship and marriage, and Mrs. Delvile's interference in Mortimer and Cecilia's courtship is negatively constructed within both ideologies. Unlike Mrs. Delvile the mothers-in-law in Sense and Sensibility are all widows, and thus they find themselves in a different conflict — between the happiness of their children and the maintenance of family wealth and propriety. Mrs. Ferrars, Mrs. Jennings, and Mrs. Dashwood all navigate this conflict differently, and together they demonstrate the vexed nature of female authority in a patriarchal world. 


\section{"What tie, what connection, could make you more dear to me?": The Mother-in-Law in Cecilia}

Like many of her contemporaries, Frances Burney usually omits the mother-in-law from her fiction. Three of the four heroines in her novels are orphans, and of the heroes, only Mortimer Delvile in Cecilia has parents—and the relationship between Mortimer's mother and the heroine is a vital part of both the plot and the novel's ideology. In her portrayal of Mrs. Delvile's development, Burney dramatizes the paradigm shift from family-governed courtship to individual-determined courtship. While Mrs. Delvile initially supports her husband's arrogant rejection of Cecilia as a suitable wife for Mortimer, her love for her son eventually causes her to sanction his marriage to Cecilia. However, her maternal relationship with Cecilia complicates Mrs. Delvile's ideological shift. Since Mrs. Delvile is like a mother to Cecilia, who lives with the Delviles for a while, Mortimer should be like a brother to Cecilia, tingeing their romance with incestuous overtones and revealing the emotional dangers within the conjugal family. The ideological instability inherent in the paradigm shift is evident through Mrs. Delvile's relationships with Mr. Delvile, Mortimer, and Cecilia.

Mrs. Delvile initially appears in the novel as an extension of her husband's family and his pride. Mr. Monckton, who has his own agenda to promote by painting the Delvile family in a negative light, asserts that Mrs. Delvile reflects the personality of her husband: "Is not Mr. Delvile the most ostentatious, haughty, and self-sufficient of men? Is not his wife the proudest of women? And is not the whole family odious to all the world?" (166). He continues to explain why Mrs. Delvile is nothing more than an extension of her husband: "They are descended from the same stock, and inherit the same self-complacency. Mr. Delvile married his cousin, and each of them instigates the other to believe that all birth and rank would be at an end in the 
world, if their own superb family had not a promise of support from their hopeful Mortimer" (167). In defending the Delvile family, Mrs. Delvile is upholding her own consanguineal relations, which are the same as her husband's, and in doing so she helps to promote his interests. Mrs. Harrel views Mrs. Delvile as more intimidating than her husband: "I assure you she is more proud and haughty even than the old gentleman. I hate the very sight of her, for she keeps every body in such awe that there's nothing but restrain in her presence" (148). The neighbors of Delvile Castle are likewise intimidated by Mrs. Delvile: “[D]isdaining to conceal either contempt or aversion, she inspired in return nothing but dread or resentment" (460). Her own courtship and marriage follow the old ideological paradigm: "she had been married to Mr. Delvile by her relations, without any consultation of her heart or her will" (461). Mrs. Delvile is characterized as inexorable and conventionally deferential to patriarchy through most of the novel, as she supports Mr. Delvile's opposition to Mortimer's courtship of Cecilia.

Mrs. Delvile's visit to the heroine upon learning of her son's engagement to Cecilia typifies her relationship with Mr. Delvile. Mrs. Delvile announces to Cecilia: "I come to you ... in the name of Mr. Delvile, and in the name of our whole family; a family as ancient as it is honourable, as honourable as it is ancient. Consider me as its representative, and hear in me its common voice, common opinion, and common address" (638). In this declaration Mrs. Delvile makes a clear connection between her marriage and her family. To her, marriage is meant to maintain the consanguineal family, and thus, Mortimer's marriage to Cecilia would be unacceptable since it would erase the Delvile name. The problem for Mrs. Delvile, she tells Cecilia, is that Mortimer "so fondly has fixed upon you his affections, that he is ready to relinquish us all in preference to subduing them" (638). Then she makes clear that the objection to the marriage is the clause in her uncle's will demanding that Cecilia's husband take the 
Beverley name in order for her to inherit his fortune. Such a demand is intolerable to the pride of the Delvile family, even though Cecilia is otherwise an ideal match for Mortimer:

There are yet other demands to which we must attend, demands which ancestry and blood call upon us aloud to ratify! Such claimants are not to be neglected with impunity; they assert their rights with the authority of prescription, they forbid us alike either to bend to inclination, or stoop to interest, and from generation to generation their injuries will call out for redress, should their noble and long unsullied name be voluntarily consigned to oblivion!” (639-40)

Mrs. Delvile continues to describe Mortimer's taking on the Beverley name with extremely heated rhetoric: doing so would effect the "utter annihilation" of the Delvile name and make him "an alien to his family" and "the destroyer of its very existence" (640). In deciding to fulfill personal desire rather than family duty, in choosing the conjugal family over the consanguineal, Mortimer would be a traitor. As Margaret Anne Doody points out, "The argument itself is all about words, or about the meaning of the world 'Delvile,' a metonym made to function as if it were literally the entity "family", (137). The name represents the consanguineal family, which Mrs. Delvile defends at the expense of the conjugal family.

Yet Mrs. Delvile's visit to Cecilia also reveals a faultline in the ideology of the consanguineal family: although the consanguineal family is upheld above all other social relationships, ultimately marriage remains a contract between two individuals. Thus, the consanguineal family is maintained, and potentially destabilized, by individual desire, and therefore, the young lovers control the fate of the Delvile family. In this conflict between Cecilia the individual and Mrs. Delvile the family representative, Mrs. Delvile's rhetoric reveals the impending collapse of the consanguineal family. Her speech repeatedly oscillates between the 
first person plural and the first person singular as she tells Cecilia, "To yourself alone, then, can we apply, and I come to you-" (638). And she later states her ambivalence more explicitly that she is "impelled to this severity, ... performing what she holds to be her duty" though she "thinks the office her bitterest misfortune" (642). When Cecilia articulates a seeming renunciation, she demonstrates her commitment to Mortimer rather than an acceptance of the importance of the consanguineal family: "Not for me, madam, shall he commit this crime, not on my account shall he be reprobated by his family!" (640). In fact, no matter what Cecilia does, her desire for Mortimer and his desire for her have irreparably disrupted the Delvile family. Mrs. Delvile makes this effect clear when she tells Cecilia that she "foresees in the rage of her husband, and the resistance of her son, all the misery of domestic contention" (642). Cecilia's interference means that Mrs. Delvile "can only secure the honour of her family by destroying its peace” (642). Thus, Mrs. Delvile sees her demand that Cecilia renounce Mortimer as a duty required by her family, and she knows that it will damage the harmony of her family even as it upholds the existence and consequence of the family name. Mrs. Delvile's rhetoric reveals the instability of marriage ideology, the ways in which the ideology damages the familial relationships it claims to support, and the ease with which the mother-in-law creates space for ideological dissent.

While Mrs. Delvile initially aligns herself with her husband, his family, and their interests, eventually her love for her son and the collapse of her marriage as she recognizes the blind prejudice of her husband produce a shift in her allegiance. In fact, she has projected her own interests onto Mortimer: "She saw in him, indeed, all her own virtues and excellencies, with a toleration for the imperfections of others to which she was wholly a stranger. Whatever was great or good she expected him to perform" (462). Like all mothers, she wants her son to marry 
well, but while his father is "impatient that some alliance should take place without further delay," Mrs. Delvile, though still concerned for the family, also considers Mortimer's desires, as she wants to "see him with propriety and with happiness disposed of" (499, emphasis added). Mrs. Delvile desires for her son what she has been unable to attain: a happy marriage. Thus, she projects a maternal fantasy onto her son, hoping to achieve through him what marriage ideology claims is available to everyone.

Although Cecilia is willing to sacrifice her desire for Mortimer to fulfill his mother's hopes for him, his desire is less easily thwarted. After he refuses to accept the news of Cecilia's renunciation, Mrs. Delvile requires Cecilia to repeat her rejection to Mortimer. During their visit Cecilia finds herself torn between two different depictions of her responsibility. Mrs. Delvile insists that Cecilia maintain her renunciation and that sacrificing her desire (as Mrs. Delvile has in her own marriage) will bring happiness: "You cannot be unhappy, you have purchased peace by the exercise of virtue, and the close of every day will bring you a reward, in the sweets of a self-approving mind" (674). Mortimer, on the other hand, recognizes the shallow comfort of such an incentive, and he urges Cecilia, "let us live to ourselves and our consciences, and leave the vain prejudices of the world to those who can be paid by them for the loss of all besides!" (675). He further implores, "What evil threatens our union, that is not imaginary? In the general commerce of the world it may be right to yield to its prejudices, but in matters of serious importance, it is weakness to be shackled by scruples as so frivolous, and it is cowardly to be governed by the customs we condemn" (676). Thus, as Cecilia, Mortimer, and Mrs. Delvile battle over the choice between maintaining the existing Delvile family or beginning a new conjugal family, they underscore the complexities and inconsistencies of marriage ideology. 
Mortimer finally insists on upholding his engagement: "I cannot, I will not give her up!nor now, madam, nor ever! - I protest it most solemnly! I affirm it by my best hopes! I swear it by all that I hold sacred!” (680). Mrs. Delvile's conflict between her familial duty and her maternal love climax here, resulting in a physiological response: "Grief and horror next to frenzy at a disappointment thus unexpected, and thus peremptory, rose in the face of Mrs. Delvile, who, striking her hand upon her forehead, cried 'My brain is on fire!' and rushed out of the room" (680). Mrs. Delvile's insistence on maintaining the Delvile family in opposition to the desires of her son is constructed as so unnatural that she becomes a kind of monster with "her face, hands and neck all covered with blood" (680). Mrs. Delvile's stroke forces Mortimer to renounce Cecilia, but eventually she approves of Mortimer and Cecilia's marriage, for the deep unhappiness of her own arranged marriage has illuminated the desirability of the marital choice for her son.

Although Mr. Delvile refuses to sanction the marriage, Mrs. Delvile chooses to grant "a separate consent, for a measure which she thought her son absolutely engaged to take" (818). As Doody explains, "Once she is weak instead of strong and successful, Mrs. Delvile begins to side with her son against her pompous and impossible husband" (140). Kay Rogers attributes Mrs. Delvile's change in allegiance to her intelligence and her vexed social position as a woman: "Because she is reasonable, but also because a woman cannot have the bland assured domination of the patriarch, she retains a sense of proportion: she [eventually] can see comic incongruity in a situation which provokes her husband to simple outrage" (90). Mrs. Delvile writes to Cecilia that she now puts her son's happiness above all other concerns: "I will no longer play the tyrant that, weighing good and evil by my own feelings and opinions, insists upon his acting by the notions I have formed, whatever misery they may bring him by opposing all his own" (821). 
Disclaiming patriarchy by renouncing the masculine role of "tyrant," Mrs. Delvile has shifted from using her power to maintain the Delvile family to authorizing the foundation of a new family, and she is rewarded in the novel for this shift to a more matriarchal power with health that is "tolerably re-established" (938).

The development of Mrs. Delvile's character is complicated by her relationship with the heroine. When Cecilia first meets Mrs. Delvile, the two women instantly like one another, and unlike Monckton, Mrs. Harrel, and the people in the neighborhood of Delvile Castle, Cecilia finds Mrs. Delvile to be "sensible, well bred, and high spirited, gifted by nature with superior talents, and polished by education and study with all the elegant embellishments of cultivation" (160). Mrs. Delvile soon fills a void in Cecilia's life, functioning as her only female mentor in London; as Cecilia stays with the Delviles in London and at Delvile Castle, Mrs. Delvile becomes a surrogate mother to the heroine, discussing Cecilia's admirers with her (469-71) and promising that once Mortimer has been married, "no care will remain in the heart of his mother, half so fervent, so anxious and so sincere as the disposal of my amiable Cecilia, for whose welfare and happiness my wishes are even maternal" (501, emphasis added). When Mrs. Delvile compels Cecilia to renounce Mortimer, she insists that, were it not for that problem of Cecilia's name, "how I should crave the blessing of such a daughter! How rejoice in joining my son to excellence so like his own, and ensuring his happiness while I stimulated his virtue!” (641). As Doody notes, "Mrs. Delvile seems the ideal mother-in-law. The author also 'cheats' us into believing that Mrs. Delvile's character is established, settled into reason and calm—unless we notice the constant clues to her still-living discontent, her 'war with the world,' her 'violent' passions" (116). The vexed nature of the relationship between Cecilia and Mrs. Delvile becomes explicit when Mrs. Delvile learns of Cecilia and Mortimer's engagement. Then, instead of 
embracing the opportunity to accept Cecilia as a daughter-in-law, Mrs. Delvile treats Cecilia haughtily and browbeats her into a renunciation, and only then does she again display affection toward the heroine, exclaiming that "now again do I know Miss Beverley!" (640). Mrs. Delvile loves Cecilia and wants her as her daughter only if she is not her daughter-in-law.

This seeming contradiction becomes clearer when Mrs. Delvile visits Cecilia just hours after the renunciation. Now that she has gained her objective, Mrs. Delvile has nothing but praise and approval for Cecilia, greeting her with: "Oh charming girl! Saver of our family! preserver of our honour! How poor are words to express my admiration! how inadequate are thanks in return for such obligations as I owe you!” (648). Mrs. Delvile valorizes Cecilia's difficult sacrifice by exclaiming: "Oh Daughter of my mind! . . noble, generous, yet gentle Cecilia! what tie, what connection, could make you more dear to me?" (651, emphasis added). Of course, Cecilia would much prefer to be Mrs. Delvile's daughter-in-law than her surrogate daughter, even if that makes her less dear to the older woman; nevertheless, Mrs. Delvile's claims as Cecilia's "mother" force Cecilia to succumb to her manipulative power. Cecilia's renunciation checks the potential for emotional incest in her relationship with Mortimer. Even Mrs. Delvile notes that her own friendship with Cecilia should have led her to expect her son to fall in love with the heroine, telling Cecilia that had she been more vigilant, "my own admiration would have bid me look forward to my son's. You were just, indeed, the woman he had least chance to resist, you were precisely the character to seize his very soul" (651-52).

Yet Cecilia's relationship with Mortimer is not the only one tinged with incest; Mortimer seems unnaturally close to his mother, and Cecilia even sees Mrs. Delvile as a rival for Mortimer's affections, telling the older woman, "Oh, madam, . . . let him, then, see me no more! - take, take him all to yourself! forgive, console him! I will not have the misery of 
involving him in repentance, nor of incurring the reproaches of the mother he so much reverences!" (675). Cecilia's renunciation precludes her from entering a marriage with potentially incestuous overtones, yet ultimately, the novel does not fully elide the potential for emotional incest in the conjugal family. When Mrs. Delvile sanctions Mortimer and Cecilia's marriage, her letter to Cecilia emphasizes her maternal relationship with the heroine: "Hasten, then, my love, to town, ... that I may bless the daughter I have so often wished to own! . . and committing to her charge the future happiness of my son, fold to my maternal heart the two objects most dear to it!" (821). Mrs. Delvile may now “own” Cecilia as a daughter. Shortly before Cecilia and Mortimer's wedding ceremony, Mrs. Delvile explicitly welcomes Cecilia as her successor to Mortimer's love, telling him, “Content yourself, however, my son, with one of $u s, \ldots$ and content yourself, if you can, though your hard lot should make that one this creature of full bloom, health, and youth!” (827, emphasis added). Thus, both forms of potential emotional incest remain in the relationships of Mrs. Delvile, Mortimer, and Cecilia.

While Burney's novel depicts the paradigm shift from consanguineal family to conjugal family, it does not unequivocally advocate the conjugal over the consanguineal—and the motherin-law is a key component to this ambivalence. She attempts to use her limited authority to manage courtship narrative, but she merely disrupts Cecilia and Mortimer's inevitable marriage, demonstrating the danger of the consanguineal family. The novel largely favors the conjugal family, as the oldest Delvile patriarch, Lord Delvile, dies near the end, while Mr. Delvile disappears after arguing with Lady Honoria about the value of the Delvile name and blood. The absence of these men in the novel's last few pages seems to signal the end of the consanguineal family and to emphasize Mortimer's position as the head of a new conjugal family. The loss of Cecilia's inheritance from her uncle also gives increased importance to the conjugal rather than 
the consanguineal family while also signaling the inevitable conflict between these two marital ideologies. However, the final paragraph does not depict a strictly conjugal family: "The upright mind of Cecilia, her purity, her virtue, and the moderation of her wishes, gave to her in the warm affection of Mrs. Delvile, and the unremitting fondness of Mortimer, all the happiness human life seems capable of receiving" (941). The new Delvile family is composed not only of Mortimer and Cecilia, but also Mrs. Delvile, who is mentioned before Mortimer as contributing to Cecilia's happy life. The novel's ambivalence toward the conjugal family might be the reason that Cecilia's happiness is "yet human . .., and as such imperfect!" (941). Thus, the novel argues against the consanguineal construction while also calling into question the conjugal. Mrs. Delvile creates space for dissent from both ideologies, separating from her husband and supporting Mortimer and Cecilia's marriage, while remaining an integral part of their new family.

"My greatest happiness would lie in promoting their marriage": The Mothers-in-Law in Sense and Sensibility

Like Cecilia, Sense and Sensibility is ambivalent about promoting a particular familial structure, and as in Burney's novel, in Austen's the mother-in-law characters-Mrs. Ferrars, Mrs. Jennings, and Mrs. Dashwood - play key roles in creating an ambivalence that calls into question the patriarchal nature of consanguineal and conjugal families as well as of courtship and marriage ideologies. Yet unlike Mrs. Delvile, the mothers-in-law in Sense and Sensibility are widows, and thus their conflict is constructed differently. While in Cecilia Mr. Delvile embodies the ideology of the consanguineal family which stands in opposition to the conjugal desires of the younger generation, in Austen's novel the consanguineal ideology is not embodied in the family patriarch, who is dead, but instead is represented by the family's wealth and reputation, an 
ideological construct that the mother is supposed to maintain. James Thompson asserts that "Austen is more concerned with financial than familial conflict," but I would argue that in Austen's novels familial conflict is often embedded in financial difficulties (140). Problems within families are revealed through financial trouble. Since Austen is more interested in the economic consequences than the emotional effects of the mother-in-law, potential incest is hardly an issue, but her involvement in courtship and marriage is problematic in a number of ways nevertheless.

Austen's widowed mothers-in-law, like all widows in the late eighteenth and early nineteenth centuries, challenge patriarchal ideology because they inhabit positions of power and possess knowledge that might threaten patriarchal control. A widow in the period not only had sexual knowledge without a husband to control her desire, but she often had command of her dowry and often her husband's money, too. As Olwen Hufton notes, "The widow who had repossessed her dowry was a source of wealth simultaneously troubling and challenging. ... [I]n a world whose value system was predicated upon female subordination to a male head of a household, and where female earning power was indeed limited, widows at all social levels posed particular problems" (225). Thus, in their position as widows, Mrs. Ferrars, Mrs. Jennings, and Mrs. Dashwood not only embody matriarchal power, but they also have assumed some patriarchal authority in the absence of their husbands. In The Ladies Calling (1673) Richard Allestree tries to control the widow's authority, demanding that the mother maintain the consanguineal family by fulfilling the father's wishes for his children:

The last Tribute she [a widow] can pay him [her deceased husband], is in his Children. These he leaves as his Proxies to receive the kindness of which himself is uncapable; so that the Children of a Widow may claim a double portion of the 
Mothers [sic] love; one upon their Native right, as hers; the other, as a bequest in right of their dead Father. And indeed, since she is to supply the place of both Parents, 'tis but necessary she should put on the affections of both and to the tenderness of a Mother, add the care and conduct of a Father. (70)

The consanguineal family structure grants the widow and the mother-in-law more authority than the conjugal, but such power depends upon her maintenance of patriarchal prerogatives. Like Mrs. Delvile the mothers-in-law in Sense and Sensibility demonstrate the vexed position of this limited female authority.

As the wealthiest matriarch in the novel, Mrs. Ferrars is the most empowered and seemingly least vexed mother-in-law, and she wields the most control over her children's courtships and marriages. She tries to bribe Edward from courting Elinor by offering him $£ 1000$ a year if he marries "the Hon. Miss Morton, only daughter of the late Lord Morton, with thirty thousand pounds," a move that John Dashwood, utterly in awe of his mother-in-law, views as evidence of her "noble spirit" and an "instance of her liberality" (224). When Mrs. Ferrars learns of Edward's engagement to Lucy Steele, she increases the enticement to $£ 1200$ a year, "and in opposition to this, if he still persisted in this low connection, represented to him the certain penury that must attend the match. His own two thousand pounds she protested should be his all” (266-67). In her attempts to direct her sons' marriages by controling their inheritance, she takes on the patriarchal role in the consanguineal family. Her utter failure-evident in Edward's marriage to Elinor and Robert's marriage to Lucy_reveals the collapse of an ideology that advances the financial interests of the parents over the emotional and sexual desires of the children. Phoebe A. Smith notes that "Mrs. Ferrars's determination to control her son Edward's vocation as well as his choice of wife has testified to her autocratic power. ... Mrs. Ferrars 
presents a parody of the principle of primogeniture” (10). Claudia L. Johnson describes Mrs. Ferrars as "utterly collusive with patriarchal interests" (70), while Rodney Farnsworth points out that although Mrs. Ferrars appropriates patriarchal power, "[s]he partly acts for non-ideological reasons and on the human level of the emotions of a mother thwarted in her expectations, as well as out of that other parental emotion of partiality to one child over another, which play so much a part of Austen's incisive view of family" (131). No matter what her motivations, however, Mrs. Ferrars fails to control the marriages of her sons, and her attempts to do so expose the absurdity of any ideology that does not consider the desires of young women on the marriage market. After the discovery of Edward and Lucy's engagement, John Dashwood tells Elinor, "We think now . . of Robert's marrying Miss Morton." Elinor replies, “The lady, I supposed, has no choice in the affair. .. . [I]t must be the same to Miss Morton whether she marry Edward or Robert.” John's response makes clear that individual personalities and desires are of little importance in the consanguineal family structure: "Certainly, there can be no difference; for Robert will now to all intents and purposes be considered as the eldest son;- - and as to any thing else, they are both very agreeable young men, I do not know that one is superior to the other" (296-97). Yet Mrs. Ferrars fails in her interference not only because the consanguineal ideology is flawed, but also because she is misguided and impotent despite her wealth. Furthermore, her inability to make distinctions between her own children signals that she is an inadequate mother, and her lack of success as a mother-in-law reflects her maternal failures.

The dinner party at John and Fanny Dashwood's Harley Street home that brings together Elinor, Lucy, and “this formidable mother-in-law" (231) illustrates Mrs. Ferrars' poisonous personality and unsuccessful attempts at manipulation. Elinor discovers Mrs. Ferrars to be "a little, thin woman, upright, even to formality, in her figure, and serious, even to sourness in her 
aspect." Her face further reflects "the strong characters of pride and ill nature" (232). She attempts to discourage Elinor from her interest in Edward by refusing to speak to her: "She was not a woman of many words ... ; and of the few syllables that did escape her, not one fell to the share of Miss Dashwood, whom she eyed with the spirited determination of disliking her at all events" (232). Instead, Mrs. Ferrars extends "graciousness" toward the Miss Steeles, and Lucy is "particularly distinguished" (232). That Lucy misinterprets Mrs. Ferrars' attitude toward her as purposely kind reveals the weak judgment of both Lucy and Mrs. Ferrars. Yet even this passiveaggressive strategy seems insufficient to Mrs. Ferrars, who further insults Elinor by praising Miss Morton's painting while looking over "a very pretty pair of screens" that Elinor painted for Fanny Dashwood (235). In response to such treatment Elinor tries to convince herself that she is grateful not to be engaged to Edward:

She had seen enough of [Mrs. Ferrars'] pride, her meanness, and her determined prejudice against herself, to comprehend all the difficulties that must have perplexed the engagement, and retarded the marriage, of Edward and herself, had he been otherwise free; - and she had seen almost enough to be thankful for her own sake, that one greater obstacle preserved her from suffering under any other of Mrs. Ferrars's creation, preserved her from all dependence upon her caprice, or any solicitude for her good opinion. (238)

Here Elinor recognizes the potential power of the mother-in-law to complicate courtship and marriage, as she "must have perplexed the engagement, and retarded the marriage."

Yet, Mrs. Ferrars ultimately fails to prevent Edward from marrying Elinor, for they value the conjugal family over the consanguineal, as does Lucy, who boldly ensnares Robert despite 
Mrs. Ferrars' clear disapproval of her as a potential daughter-in-law. Mrs. Ferrars continues in her attempt to convince Edward not to marry Elinor, yet eventually she admits defeat:

[W]hen she found that, though perfectly admitting the truth of her representation [that he would be better off financially and socially if he married Miss Morton instead], [Edward] was by no means inclined to be guided by it, she judged it wisest, from the experience of the past, to submit — and therefore, after such an ungracious delay as she owed to her own dignity, and as served to prevent every suspicion of good-will, she issued her decree of consent to the marriage of Edward and Elinor. (373-74)

She even visits them after their marriage and "treat[s] them with the make-believe of decent affection" (375). However, "her real favour and preference" are granted to Robert and Lucy, thanks to Lucy's "cunning": "But perseverance in humility of conduct and messages, in selfcondemnation for Robert's offence, and gratitude for the unkindness she was treated with, procured her in time the haughty notice which overcame her by its graciousness, and led soon afterwards, by rapid degrees, to the highest state of affection and influence" (375, 377). Mrs. Ferrars attempts to direct the marriages of her sons but ultimately is instead manipulated by the conniving but vulgar Lucy Steele. Emotionally, Edward and Elinor win the most in this conflict, by achieving the happy marriage that they desire. Yet, they lose economically, as Mrs. Ferrars maintains her financial power. In negotiating the ideological demand that she both promote the family wealth and ensure the emotional wellbeing of her children, Mrs. Ferrars attempts to fulfill only the former, and thus, she maintains her own economic power and the disingenuous deference of Robert and Lucy, but both of her sons marry penniless women, and Mrs. Ferrars further loses the respect of Edward, Elinor, and the reader. In displaying blatant favoritism and 
mindlessly falling for Lucy's pandering to her vanity, Mrs. Ferrars fulfills the negative stereotype of the mother-in-law (and of women).

Although Mrs. Jennings does not seem to be quite as well off as Mrs. Ferrars, she nevertheless is wealthy enough to own a house in London and to wield some influence over her adult daughters. The narrator's description of Mrs. Jennings succinctly reveals her character, power, and methods:

Mrs. Jennings was a widow, with an ample jointure. She had only two daughters, both of whom she had lived to see respectably married, and she had now therefore nothing to do but to marry all the rest of the world. In the promotion of this object she was zealously active, as far as her ability reached; and missed no opportunity of projecting weddings among all the young people of her acquaintance. She was remarkably quick in the discovery of attachments, and had enjoyed the advantage of raising the blushes and the vanity of many a young lady by insinuations of her power over such a young man. (36)

While the widowed Mrs. Ferrars seems to have control of the family wealth (as evidenced by her power of disinheritance), the widowed Mrs. Jennings has only a jointure.* Nevertheless, as a widow whose children are grown and married and who enjoys "an ample jointure," Mrs. Jennings possesses the financial and social independence to play matchmaker to "the rest of the world," and the strategy of raillery that she enacts suggests the method she used to find husbands for her own daughters. When Elinor and Marianne first meet Mrs. Jennings, she "said many witty things on the subject of lovers and husbands; hoped they had not left their hearts behind them in Sussex, and pretended to see them blush whether they did or not" (34). When she determines that "Colonel Brandon was very much in love with Marianne Dashwood," she is 
"supplied . . . with endless jokes against them both" (36). Mrs. Jennings attempts to control courtship narrative by inserting herself in situations where her interference is inappropriate. Although such methods are vulgar and create awkward social situations, they do not attempt to force people to marry against their will, as Mrs. Ferrars' bribes do. Yet Mrs. Jennings possesses an impressive record of encouraging economically advantageous marriages, as her daughters have married well; apparently, she was significantly involved in the courtships of her daughters, as Charlotte tells Elinor that she might have married Colonel Brandon except "mama did not think the match good enough for me" (116). Although Brandon never demonstrated any interest in Charlotte, as Thompson points out, her comment reveals her "confidence in her mother's duty and ability to arrange her marriage to someone or other" (138). However, although the marriage of Mrs. Jennings' daughters are economically advantageous, Lady Middleton and Mrs. Palmer seem mismatched to their husbands in terms of personality; the reserved Lady Middleton only accentuates the animation of Sir John, while Mr. Palmer's dour satire highlights his wife's giddiness.

The awkwardness of these marriages is illustrated during a dinner conversation at the Middletons' house in London, a scene that justifies quoting at length:

When they were seated in the dining room, Sir John observed with regret that they were only eight altogether.

"My dear," said he to his lady, "it is very provoking that we should be so few. Why did not you ask the Gilberts to come to us to-day?"

"Did not I tell you, Sir John, when you spoke to me about it before, that it could not be done? They dined with us last." 
"You and I, Sir John," said Mrs. Jennings, "should not stand upon such ceremony."

"Then you would be very ill-bred," cried Mr. Palmer.

"My love, you contradict every body," — said his wife with her usual laugh. "Do you know that you are quite rude?"

"I did not know I contradicted any body in calling your mother ill-bred."

"Aye, you may abuse me as you please," said the good-natured old lady, "you have taken Charlotte off my hands, and cannot give her back again. So there I have the whip hand of you." (111-12)

This scene reveals a number of oddities in the extended Jennings family and in Mrs. Jennings' relationship with her sons-in-law. She sides with Sir John against the decorum of her daughter. She and Sir John are such gregarious people that they often extend invitations together to Barton Park, almost as if she is Sir John's wife rather than his mother-in-law $(99,118)$. Her relationship with Mr. Palmer, on the other hand, would be strained save for her refusal to take him seriously, an attitude that her daughter emulates. Mrs. Jennings is proud to have found financially advantageous husbands for her daughters and is unperturbed by the apparent mismatch in their personalities, laughing at the permanence of these incompatible marriages. And "spending a large portion of the year at the houses of her children and friends" despite having her own house in London (153), Mrs. Jennings clearly values the consanguineal over the conjugal family, while her daughters' marriages illustrate the folly of such a preference. In aiming at merely preserving the wealth and blood of her family, Mrs. Jennings carelessly relegates her daughters to marriages that fail to be fully satisfying, even if her daughters seem to lack the self-awareness to be discontented in their marriages. Thus, like Mrs. Ferrars, Mrs. Jennings chooses to promote her 
family's economic wellbeing rather than encourage her daughters to find emotional fulfillment in marriage, revealing the difficulty of fulfilling all the demands of marriage ideology.

Unlike Mrs. Ferrars and Mrs. Jennings, Mrs. Dashwood has little money, and not surprisingly, she attempts little interference in the courtships and marriages of her daughters. Claudia Johnson notes that because Mrs. Dashwood "has no money to enforce her policies," her "authority is entirely noncoercive" (70). Both Johnson and Mrs. Dashwood seem to overlook the possibility of non-financial ways of enforcing parental authority. Yet while the novel is clearly critical of the meddling of Mrs. Ferrars and Mrs. Jennings, neither does it commend Mrs. Dashwood's laissez-faire parenting. She allows her daughters to make their own choices in courtship, and she wholeheartedly promotes those choices. When she realizes that Elinor and Edward are falling in love, she remains at Norland despite her aversion to Fanny: "It was contrary to every doctrine of her's that difference of fortune should keep any couple asunder who were attracted by resemblance of disposition" (15). When Marianne falls for Willoughby, Mrs. Dashwood is led by her daughter's judgment: “In Mrs. Dashwood's estimation, he was as faultless as in Marianne's" (48). While accepting her daughters' opinions of their suitors, Mrs. Dashwood grants her daughters romantic agency by avoiding any involvement in their courtships that is not specifically sanctioned by them, refusing, for example, to ask Marianne directly if she is engaged to Willoughby. She tells Elinor, "I would not ask such a question for the world! . . I should never deserve her confidence again, after forcing from her a confession of what is meant at present to be unacknowledged to any one" (84). Not surprisingly, Mrs. Dashwood is specifically critical of the intrusive Mrs. Ferrars. When Edward arrives at Barton Cottage "not in spirits, ... Mrs. Dashwood, attributing it to some want of liberality in his mother, sat down to table indignant against all selfish parents" (90). Yet this strategy fails to create smooth 
courtships for her daughters, for Marianne nearly dies of a broken heart (and additionally faces the danger of seduction and abandonment by Willoughby), and Elinor cannot marry Edward until his engagement to Lucy is ended. Thus, while the dictatorial mothers-in-law fail to promote emotionally satisfying unions for their children, the indulgent mother risks failing to advance any marriage for her children.

Eventually Mrs. Dashwood does promote successfully the marriages of Elinor and Edward, and Marianne and Colonel Brandon. When Brandon divulges to her that he loves Marianne, Mrs. Dashwood immediately approves of the match, telling Elinor, "Had I sat down to wish for any possible good to my family, I should have fixed on Colonel Brandon's marrying one of you as the object most desirable. And I believe Marianne will be the most happy with him of the two" (336). Mrs. Dashwood further insists that "my greatest happiness would lie in promoting their marriage" (337), and explains her reasons for doing so. First, Brandon loves Marianne: "His regard for her, infinitely surpassing anything that Willoughby ever felt or feigned, as much more warm, as more sincere or constant ... has subsisted through all the knowledge of dear Marianne's unhappy prepossession for the worthless young man! ... Such a noble mind! — such openness, such sincerity! —no one can be deceived in him" (336-37). Brandon has proven his love, in Mrs. Dashwood's eyes, by fetching her to Cleveland when Marianne falls ill: "But his coming for me as he did, with such active, such ready friendship, is enough to prove him one of the worthiest of men" (337). Second, Mrs. Dashwood is certain that Marianne will eventually fall in love with Brandon: "[H]is disposition, I am well convinced, is exactly the very one to make your sister happy. And his person, his manners too, are all in his favour" (338). She also praises the "gentleness" of his manners, with "their genuine attention to other people, and their manly unstudied simplicity" (338). Finally, after discussing his feelings, 
body, and personality as all reasons to promote him as Marianne's suitor, she adds, "His fortune too! - for at my time of life you know, everybody cares about that; - and though I neither know, nor desire to know, what it really is, I am sure it must be a good one” (339). For Mrs.

Dashwood, unlike Mrs. Ferrars or Mrs. Jennings, Brandon's wealth is valuable only as it will contribute to the happiness of her daughter, rather than the primary reason for promoting the marriage, and her comment may even be a grudging concession to Elinor that a marriage does require some income, despite the idealistic vision of romance she shares with Marianne earlier in the novel.

Notwithstanding Marianne's earlier horrified reaction to Mrs. Jennings' jokes about Brandon's admiration of her, Mrs. Dashwood is certain that Brandon's “merits must soon secure" Marianne's heart (337), and while Mrs. Dashwood never pressures Marianne to accept Brandon's suit, her love for Brandon does in time "burst on her" (378). Thus, Mrs. Dashwood eventually recognizes the right match for Marianne, but she does not force her daughter into marriage. Although Mrs. Dashwood's strategy of laissez-faire parenting nearly turns disastrous, ultimately by encouraging her daughters to seek happiness in marriage, she sees both Elinor and Marianne settled in loving, socially appropriate unions, fulfilling the goals of the conjugal family. She further promotes the objective of the conjugal family by remaining in her own home, unlike Mrs. Jennings, instead of imposing her daily presence and potential interference on her daughters (380). Mrs. Dashwood's own apparently happy marriage and her dislike of (and disappointment in) her husband's extended family undoubtedly have contributed to her promotion of the conjugal family over consanguineal relations.

While Mrs. Dashwood develops a positive and loving relationship with her sons-in-law, her relationship with Fanny Dashwood, her step-daughter-in-law, is far more vexed. Fanny's 
lack of consideration for others disgusts the sensitive Mrs. Dashwood, and Fanny's selfishness becomes more apparent when she moves into Norland immediately after Mr. Dashwood's death: "Mrs. John Dashwood had never been a favourite with any of her husband's family; but she had had no opportunity, till the present, of shewing them with how little attention to the comfort of other people she could act when occasion required it" (6). When Fanny promotes the prerogative of the consanguineal family and openly opposes Edward and Elinor's relationship, Mrs. Dashwood immediately moves with her daughters to Devonshire, and she avoids seeing Fanny throughout the rest of the novel. Mrs. Dashwood (perhaps partly because she was Mr. Dashwood's second wife) values emotional attachments more than blood or wealth in determining familial ties, and the conjugal family structure best supports such attachments. While none of the parenting styles portrayed in Sense and Sensibility guarantees a successful courtship, Mrs. Dashwood's emphasis on finding husbands who will fulfill the emotional and sexual desires of her daughters succeeds, and thus achieves the goals of the conjugal family. However, her near failure, along with the failures of Mrs. Ferrars and Mrs. Jennings to promote truly satisfactory marriages for their children, reveal faultlines in courtship and marriage ideologies, emphasizing the potential contradiction in the ideological demands that marriage be advantageous financially and emotionally. Furthermore, mothers are expected to help promote successful marriages, yet mothers-in-law are often seen as meddlesome, disrupting and stalling courtship rather than supporting it. Thus, the mother-in-law also illustrates another ideological faultline: women have specific duties in courtship and marriage, but the power to fulfill these duties is seen as unfeminine and improper. 


\section{Conclusion}

Both consanguineal and conjugal family structures in the late eighteenth and early nineteenth centuries were patriarchal, and the few courtship novels that portray the mother-inlaw reveal her potential power. In his 1797 conduct manual An Enquiry into the Duties of the Female Sex Thomas Gisborne recognizes this potential power, especially as it affects her children-in-law, and he attempts to control it by advising her to accept these new family members kindly:

When matrimonial alliances introduce a mother to new sons and new daughters; let her study to conduct herself towards them in a manner befitting the ties of affinity, by which she is now united to them. If she harbours prejudices against them, if pride, jealously, caprice, or any other unwarrantable emotion marks her behaviour towards them; the injustice of her conduct to the individuals themselves has this further accession of criminality, that is also wounds in the tenderest point the feelings of her own children. (396-97)

In accepting children-in-law, the mother-in-law promotes the conjugal family by putting the desires of her children above her own and those of her husband and family. Ensuring that her children have made wise choices in marriage helps the mother-in-law accept new family members.

Yet the benevolent mother-in-law possesses latent power that challenges patriarchy. Any involvement in her children's courtships may usurp power from patriarchal figures - fathers and future husbands. The mothers-in-law in Cecilia and Sense and Sensibility demonstrate that the more of this power a woman assumes, the more likely that she will be constructed negativelyas these women disrupt, interrupt, and misshape the courtship and marital narratives of their 
children. Alan Sinfield notes that women in Shakespeare's plays may script (i.e., write their own stories), "but their scripts lead to the surrender of their power in the larger story of marriage," and "women who script men are bad" (33). In the novels discussed in this chapter, the motherin-law characters who attempt to control courtship narrative are attempting to script men, and thus, they are portrayed negatively: Mrs. Delvile's refusal to sanction Mortimer and Cecilia's marriage directly contributes to her stroke, while Mrs. Ferrars is characterized as ugly, stupid, and mean and Mrs. Jennings is old, fat, and vulgar. Yet Mrs. Dashwood is portrayed as weak and misguided, and her hands-off strategy nearly results in the death or social ruin of her daughter. Mothers-in-law illustrate the refusal of the patriarchal family, whether it emphasizes consanguineal or conjugal ties, to accept women as authority figures.

Sinfield points out that marriage, as the patriarchal transfer of a woman from her father's household to her husband's, is ideologically fraught:

Ideally, from the point of view of the social order, it would all be straightforward. The woman's transition from daughter to wife - from one set of duties to another-would be accomplished smoothly, with the agreement of all parties. But things could go wrong here; it was an insecure moment in patriarchy. The danger derived from a fundamental complication in the ideology of gender relations. Marriage was the institution through which property arrangements were made and inheritance secured, but it was supposed also to be a fulfilling personal relationship. It was held that the people being married should act in obedience to their parents, but also that they should love each other. (42-43)

Because she is also expected to uphold these potentially contradictory ideological demands, the mother-in-law embodies this faultline, and she can have a significant influence on courtship 
narrative by promoting bad or mediocre marriages (like Mrs. Ferrars and Mrs. Jennings) or by forestalling good marriages (like Mrs. Delvile). Furthermore, like Mrs. Delvile, she can indicate problems in marriage ideology through her own marriage. That courtship and marriage prevail in these novels despite the mothers-in-law signals the continuing strength of patriarchal ideology. Nevertheless, the mother-in-law has exposed space for dissent — through her own imperfect marriage or through the marriages that she creates - that continues to question courtship and marriage ideologies.

\footnotetext{
* Susan Staves has discussed at length the shift during the long eighteenth century from dowry to jointure. She argues that jointures were often less advantageous for women than dowries: "A widow's entitlement to a life estate in land was transformed by equity into an entitlement to a jointure that could be a smaller estate in less secure personal property for less than the term of her life" (99). Ruth Perry notes: "Jointure provisions, however generous, were generally less than the third of the estate which was a widow's dower right by common law" (53). Thus, Mrs. Jennings has more money than the poverty-stricken Mrs. Dashwood, but enjoys a smaller income than she might have earlier in the period.
} 


\section{Chapter 3}

\section{“What Have I To Do with Matrimony?": Marriage Ideology, the Governess, and Dissent in Camilla and Emma}

Studies of the governess in British literature generally focus on the Victorian period. No major eighteenth-century novel has a governess heroine comparable to Jane Eyre, and scholars have largely ignored the role of the governess in literature of the long eighteenth century. ${ }^{1}$ Yet examining the governess during this period is valuable for two reasons. First, the definition of the term was evolving. Gradually a governess was less often used to refer to "a female governor or ruler" and more often meant as "a female teacher"-initially any female teacher but increasingly, though not exclusively, by the end of the period "one so employed in a private household." ${ }^{2}$ For example, Moll Flanders, using the older definition, refers to an older woman who aids and advises her as her "governess" in Defoe's 1722 novel. By mid-century, the term generally meant any female teacher, and Sarah Fielding employs this definition in her 1749 novel The Governess. Yet by the end of the century, even the latest definition of "a female teacher ... employed in a private household" retained connotations of governing children in addition to teaching them. Thus, the evolution of the definition of the term reflects the rise of the profession of governess as more women were privately employed female teachers, and it also signals an expanding emphasis on female education throughout the eighteenth century. As a female instructor, the governess, like the mother, was a woman who had a limited amount of authority, and as I will explore further in this chapter, her limited authority also restricted the governess's instructional and professional success. In Advice to a Daughter (1688), Halifax overtly confers the "government" of children upon mothers as well as fathers; he counsels his daughter to earn respect in her household by being involved in the government of it, and he 
grants a mother "a more immediate Jurisdiction" over her daughters than her sons (70, 81). As the governess, rather than the mother, became more likely to educate girls and pre-school boys in leisure-class homes during the eighteenth century, she acquired some, though not all, of the mother's authority. Thomas Gisborne, in his conduct manual Enquiry into the Duties of the Female Sex (1797), advises the mother to observe and govern the governess: "Let the assistant be ever treated with friendly kindness. But let her be kept attentive to the duties of her office by the superintending vigilance of the parent" (370). Thus, the governess is granted some authority over the children, but she remains the mother's "assistant" while the parents retain their authority and also possess managerial authority over the governess. Such overlapping of authority in the hierarchy of familial power points to ambivalence in the governess's position in the household, and this ambivalence will be explored at length in this chapter.

Second, the increasing importance of the governess in the long eighteenth century results from her deep entanglement in courtship and marriage ideologies, as well as from her ambivalent position in class ideology. In both Frances Burney’s Camilla and Jane Austen's Emma the role of the governess reveals space for dissent from courtship and marriage ideologies. ${ }^{3}$ Although Miss Margland, the governess in Camilla, and Mrs. Weston and Jane Fairfax, former and potential governesses in Emma, are relatively minor characters, they nevertheless challenge the ideology that marriage is natural for women by revealing the work that courtship requires for a leisure-class woman to attain the "natural" role of wife. Published twenty years apart, Camilla (1796) and Emma (1816) both embody the potential challenge that the governess presents to marriage ideology. The governess in the late eighteenth century and throughout the nineteenth century was usually an unmarried impoverished gentlewoman who needed respectable employment to provide for her economic needs. This anxiety lies beneath many courtship novels 
of the period: if a leisure-class woman did not marry, how would she survive? Eighteenthcentury leisure-class British culture displayed anxiety about female work itself: what kind of work was appropriate for a leisure-class woman? And what work was available and sufficiently remunerative for a woman trained for leisure? In this way, the governess called into question British class ideology, which emphasized either class stasis or upward mobility but always elided downward mobility. Yet such downward mobility not only was probable but likely for women, because of the high ratio of women to men in the eighteenth century as well as the tradition of primogeniture, which reduced daughters' dowries. ${ }^{4}$ In addition, marriage ideology relied upon the governess to prepare young women for the marriage market (which she had not successfully navigated), rather than mothers, who were often dead, preoccupied with other duties, or incompetent. ${ }^{5}$ In other words, no matter which motherly failure threatened marriage ideology, the governess was expected to cover the fissure in order to replicate that ideology. Thus, the governess both presented an alternative to marriage that inevitably revealed a degree of female agency and also offered a challenge to both class and marriage ideologies.

This challenge is revealed differently in Burney's and Austen's novels. Miss Margland embodies the governess in practice, while Mrs. Weston and Jane Fairfax exemplify governesses only in theory, since they do not work as governesses during the action of the novel. In Camilla the role of Miss Margland provides space to question the efficacy of the governess and the limits of her agency, which in turn challenges the courtship and marriage ideology that creates her, marginalizes her, and requires her to perpetuate it. In Emma the discussion of the governess as a female profession also engages with questions of female agency, and more important, it opens space for the role as an alternative to the role of wife, and calls into question the marriage ideology that elevates the role of wife at the expense of other alternatives, both desired and 
necessary. Both novels, however, stop short of fully critiquing marriage ideology in so far as they use marriage to attempt to erase the ideological challenge of the governess. Miss Margland's failure as a governess does not prevent any of the young women in Camilla from marrying, and both Miss Taylor and Jane Fairfax escape the fact or the threat of governessing through their own marriages. Yet the attempted reinscription fails to erase the governess's challenge to the system. Instead of covering the ideological faultline that the narratives reveal, the attempted erasure of the governess in these novels only draws attention to the ideological faultline, by reflecting and emphasizing eighteenth-century British society's marginalization of the governess. Thus, the role of the governess in Camilla and Emma succeeds in opening up a space for ideological dissent. Although, as I explore in this chapter, this space is limited-as Alan Sinfield notes, "dissident opportunities always are limited" (45) - the fact that it is opened indicates the instability of the courtship, marriage, and class ideologies of the late eighteenth and early nineteenth centuries.

\section{“Offices for the Sale ... of Human Intellect": The Governess and Social Anxiety}

A gentlewoman, as a function of her class and gender, was not employed, but the governess contradicted this social definition. M. Jeanne Peterson describes the governess as "a lady, and therefore not a servant, but she was an employee, and therefore not of equal status with the wife and daughters of the house" (15). The ambiguous social position of the governess blurred class lines and thus created anxiety for herself and for everyone around her. This anxiety results in what Peterson, analyzing governesses in the Victorian period, labels with the sociological term "status incongruence" (15). Camilla and Emma, as well as the writings of Mary Wollstonecraft, reveal that the status incongruence of the governess existed at the end of 
the long eighteenth century. Failing to attain the goals of the leisure class, the governess was experiencing downward mobility.

While the ideology of the leisure class asserted the importance of acquiring wealth and rising socially, the governess's downward mobility demonstrated that such a goal was not always plausible. In Vindication of the Rights of Woman (1792), Wollstonecraft, who had experienced the role of governess firsthand, describes the position as a demeaning one: "But as women educated like gentlewomen, are never designed for the humiliating situation which necessity sometimes forces them to fill; these situations are considered in the light of a degradation; they know little of the human heart, who need to be told, that nothing so painfully sharpens sensibility as such a fall in life" (219). In Thoughts on the Education of Daughters (1787) Wollstonecraft further details the situation of governesses: "It is ten to one if they meet with a reasonable mother; and if she is not so, she will be continually finding fault to prove she is not ignorant, and be displeased if her pupils do not improve, but angry if the proper methods are taken to make them do so. The children treat them with disrespect, and often with insolence" (25). Here conflict arises between the governess and the family because, as noted earlier, the governess both is and is not an authority figure. Both she and the parents have authority over the children, but the parents also have authority over the governess, so conflicts over discipline arise between the governess and the parents. If the children become aware of such conflicts, they mimic the disrespect of the governess that their parents display. Thus, the governess occupies an ambiguous position in both the household and society. As an employee, she has a lower status within the household, even though she may be better educated than the lady of the house. The mother, therefore, may criticize the governess merely to maintain her household authority and social status, and the children imitate such treatment by disrespecting the governess's authority. 
The governess also experiences a loss of status outside the household because she is an employed woman. Thus, because of the governess's ambiguous position in both household and social hierarchies, relationships between governesses and those with clear and more stable class positions often become fraught with tension and produce contests over status.

Thus in Camilla, the irritable Miss Margland continually worries about being treated with the respect that she believes is her due: "The spirit of Miss Margland was as haughty as her intellects were weak; and her disposition was so querulous, that, in her constant suspicion of humiliation, she seemed always looking for an affront, and ready primed for a contest" (46). She struggles with Camilla for influence over Sir Hugh, and she behaves coldly to Mr. Westwyn and any other person she believes is not above her social status. In this way, Miss Margland fights against the class system that demotes her by emphasizing her own importance, and yet she simultaneously reinforces the system by deferring to those above her on the social ladder and oppressing those below her. The combination of her bad temper and her hauteur leads Lionel Tyrold to target her repeatedly for his practical jokes, from the affair with the bull (125-47) to Mr. Dubster's suit for Camilla's hand (596-606). Her unguarded, though understandable, anxiety for her social position only reduces respect for her, for even the servants refer to her as "the cross old Frump" and "a nasty old viper" (350). Yet her irritability results from her insecurity: "It not seldom occurred to Miss Margland to be cross merely as a mark of consequence" (747). As an employee, a governess typically lacks the freedom to express anything but a pleasant temper. By being irritable, Miss Margland asserts that her position is secure enough to allow her this freedom. Thus, Miss Margland finds herself caught in a vicious cycle of class anxiety that is legitimate to some extent, but her behavior only exacerbates it: she 
is cross because she is insecure, and then she is attacked and teased because she is cross, which only increases her anxiety and her bad temper.

While Miss Margland represents the anxiety of the governess about her social position, in Emma the ambiguous nature of the governess's position in society is emphasized not by the real or potential governesses_-Mrs. Weston or Jane Fairfax — but by Mrs. Elton, arguably the most socially anxious character in the novel, who calls herself "Lady Patroness" (332). Intent on social upward mobility, she uses Jane Fairfax's liminal status to increase her own importance in Highbury society by patronizing Jane, even though she has not yet become a governess. Mrs. Elton calls Jane by her first name, a familiarity that, developing immediately upon Mrs. Elton and Jane's acquaintance, emphasizes that Mrs. Elton patronizingly views herself as Jane's mentor, rather than as her close friend. Such an action is so inappropriate that it even draws a remark from Frank: “'Jane!'—repeated Frank Churchill, with a look of surprise and displeasure.- "That is easy"' (304). Since in the eighteenth century only close friends, some family members, and social inferiors were addressed by first name, Mrs. Elton attempts to establish her own social status (as the daughter of an affluent merchant) by placing "Jane" below her on the social ladder. That the vicar's wife intends to raise herself above Jane socially becomes clear through her behavior, which signals Mrs. Elton's insecurity about her own social status. She forces Jane to accept her aid in obtaining a position as a governess, expects Jane to keep her company whenever she desires, and calls attention to any favor she does for Jane, such as transporting her in the Eltons' carriage. Since patronage is traditionally an act of the upper class, the distinctly middle-class Mrs. Elton's efforts seem particularly impertinent as she treats Jane as a lady's companion as preparation for becoming a governess, and Mrs. Elton's actions 
point as much to her concerns for her own social status as to her anxiety about Jane's status.

Shortly after her arrival in Highbury, Mrs. Elton explains her plans for Jane to Emma:

I quite rave about Jane Fairfax.- A sweet interesting creature. So mild and ladylike — and with such talents! . . I talk of nothing but Jane Fairfax.-And her situation is so calculated to affect one! ... I shall certainly have her very often at my house, shall introduce her wherever I can, shall have musical parties to draw out her talents, and shall be constantly on the watch for an eligible situation. My acquaintance is so very extensive, that I have little doubt of hearing of something to suit her shortly. $(262-64)^{6}$

Mrs. Elton's just praise of Jane's talents is so tainted with her self-consciousness of class status that it becomes condescending and unsympathetic.

Jane's beauty and musical talent remain undisputed in Highbury (except for Frank Churchill's disparaging comments, which are meant merely to disguise his secret engagement to Jane), but lacking a fortune, her chances of success on the marriage market are so slim that from childhood she is expressly educated to become a governess: "The plan was that she should be brought up for educating others; the very few hundred pounds which she inherited from her father making independence impossible" (154). As a beautiful and talented young woman, Jane is a sympathetic representation of what is wrong with the marriage market, and finding "an eligible situation" could prove more difficult than Mrs. Elton admits, since many mothers will not appreciate being compared to a more beautiful, more talented governess, or risk seduction within their households, especially by the master of the house or an older son. Despite Jane's sympathetic situation, however, Mrs. Elton's patronage is self-interested. As Margaret Lenta explains, "From the moment that she understands Jane's position, Mrs. Elton appropriates her as 
a kind of unpaid lady-in-waiting and obliges her to receive a kind of patronage which emphasizes their status" (30). Whether she is insecure about her socially ambiguous position, desires social interaction with someone outside her family (which Emma fails to provide), or is simply overpowered by Mrs. Elton’s forcefulness, Jane accepts Mrs. Elton’s officious attention. Jane quietly resists only twice, when Mrs. Elton's efforts threaten her situation as Frank Churchill's fiancée: she opposes Mrs. Elton's attempts to prevent her trips to the post office and the overly zealous efforts to secure her a governessing position, though when Jane's relationship with Frank deteriorates she considers taking the position that Mrs. Elton is brokering.

With such overbearing and oppressive patronage, it is little wonder that Jane describes the position of the governess in language that makes Mrs. Elton insensitively think of the slave trade. When Mrs. Elton's attempts to find a job for her become overwhelming, Jane tries to check her by stating: "When I am quite determined as to the time, I am not at all afraid of being long unemployed. There are places in town, offices, where inquiry would soon produce something — Offices for the sale — not quite of human flesh — but of human intellect" (279). When Mrs. Elton misinterprets her to "mean a fling at the slave-trade," Jane clarifies: "I was not thinking of the slave-trade ... ; governess trade, I assure you, was all that I had in view; widely different certainly as to the guilt of those who carry it on; but as to the greater misery of the victims, I do not know where it lies" (279-80). What Jane means by "Offices for the sale—not quite of human flesh—but of human intellect" has been debated by scholars. Juliet McMaster seems to find Jane's denial that she was "thinking of the slave-trade" to be disingenuous, as she sees the "alignment with the slave trade [to be] explicit," but McMaster also recognizes "a passing hint, too, of prostitution" (126). Claudia Johnson notes that "governesses were typically suspected of an interest in selling their flesh as well" as their intellect (137). Gabrielle D. V. 
White, on the other hand, asserts that Jane is making another connection-between the "human flesh" of slavery and the "one flesh" of marriage vows - a connection that questions the morality of marrying for money, which one could argue is a kind of prostitution, instead of marriage for love. In this way, Jane "can also be seen chiding Mrs Elton for, at no stage, ever regarding her as having any marital prospects" (55).

Whether Jane's metaphor of "the sale . . of human flesh" refers to slavery, prostitution, or pecuniary marriage, none of these referents gives a flattering portrayal of the plight of the governess. By the early nineteenth century, abolition had gained popularity in England, and many people were aware and horrified by the inhumanity of slavery. Within England, slavery was illegal, and slave trade by British ships had been outlawed by the Slave Trade Act of 1807. The sale of human flesh was seen as abhorrent. Prostitution was also detested, and the ideology of marrying for love had gained acceptance, at least theoretically, especially for the leisure classes, although in reality social and economic issues were still carefully considered. Jane, however, argues that the sale of human intellect, though accepted by society, is nearly as demeaning as slavery, prostitution, and pecuniary marriage, an argument that Wollstonecraft supports by her repeated assertions that governessing is a "humiliating" profession that causes its victims misery. Jane also reflects, through Austen's indirect discourse, on the miseries of the governess: "With the fortitude of a devoted noviciate, she had resolved at one-and-twenty to complete the sacrifice, and retire from all the pleasures of life, of rational intercourse, equal society, peace and hope, to penance and mortification for ever" (165). The governess is a slave in that she loses both social position and personal autonomy, and she is a prostitute in that she earns a living by sharing with others the intellectual, cultural, and social skills that women generally reserved for their husbands and families. The associations among slavery, prostitution, 
and governessing emphasize the liminal social position of the governess and the desperation caused by her downward mobility. Mrs. Elton further vocalizes the ambiguous position of the governess when she expresses surprise that Mrs. Weston was Emma's governess, stating: "I was rather astonished to find her so very lady-like! But she is really quite the gentlewoman" (258). Emma quickly reminds Mrs. Elton that the governess's occupation depends on her being a gentlewoman: “Mrs. Weston's manners ... were always particularly good. Their propriety, simplicity, and elegance, would make them the safest model for any young woman" (258). As a merchant's daughter moving aggressively up the social ladder, Mrs. Elton pointedly and repeatedly emphasizes her status as a vicar's wife and a gentlewoman by snobbishly looking down on less financially fortunate gentlewomen, such as Jane Fairfax, Miss Bates, Harriet Smith, and even Mrs. Weston. ${ }^{7}$

The ambiguous social position of the governess and the resulting social anxiety are evident not only in fiction of the period, but also in the historical record. The extensive letters and journals of Agnes Porter, a governess in the late Georgian period, reveal the social and material conditions for a governess, including battles over status. Porter was not afraid to defend her social position against those who looked down upon her because she was a governess. One such incident occurred in 1802 when she was employed by the Talbot family, who lived at Penrice Castle in a remote area of Wales. In such a rural area the Talbots' social circle was understandably small, and it included people who were middle class, even though Lady Mary Talbot was the daughter of an earl, Lord Ilchester. Because Porter was both a gentlewoman and an employee, tension arose when people did not know whether to treat Porter as an equal or as an inferior. On one occasion as Porter rose to leave after visiting with the vicar and his wife, another visitor demonstrated confusion about whether or not it was appropriate to help her with 
her cloak. In her journal Porter wrote: "Mrs Pryce, who sat next to me and who is of a most obliging temper, offered to assist me with my cloak. Her husband made her a sign of disapprobation, and in some confusion she dropt the string and pretended to have her attention called another way" (216). The next day when Mr. and Mrs. Pryce visited Penrice Castle, Agnes “watched Mrs Pryce's movements, to assist her with her cloak, and on [Mr Pryce's] eyeing us I said, half smiling, half serious, 'Hail the small courtesies of life, for smooth do they make the road of it!' [a quotation from Laurence Sterne's A Sentimental Journey]. I looked up at Mr Pryce — he cast his eyes down —I had my revenge" (216). By proving herself to be more mannerly than Mr. Pryce, Porter not only reasserted her social position despite the anxiety it may have caused the Pryces, but she signaled her superiority to Mr. Pryce because of her social deftness, generosity, and literary accomplishment.

\section{"I Had Performed the Part Assigned to Me": The Governess as Educator}

The contradiction inherent in the governess's position as an employed gentlewoman becomes evident in the occupational expectations of her employers. The governess's job was to educate her pupils; daughters generally stayed at home under the governess's tutelage until they "came out," while sons studied under the governess until they went to boarding school. Agnes Porter's letters and journals reveal the disciplines she taught her charges: she taught "history, French and English, music and geography," as well as arithmetic, a little Italian, and "the art of sewing" $(119,139)$. Porter also focused on moral education; she heard her pupils say their "prayers, part of the catechism and a hymn" (208). She "amused them with a little history from the Bible," and she noted that she aimed "to make that holy book dear to them from their earliest years" (208). She used stories to emphasize virtues such as sharing, and in a letter to one of her former pupils she commented that she had corrected errors of conduct, using "no ceremony with 
any one of you in a point so essential to your happiness" (190). Porter's method of using stories to instill moral values mirrors that of the governess Mrs. Mason in Wollstonecraft's Original Stories (1796), in which the diligent Mrs. Mason finds her pupils, Mary and Caroline, not "merely ignorant" but having "caught every prejudice that the vulgar causally instill," and thus, the governess focuses on removing these moral faults from her students (361). Although a focus on moral education was expected from all governesses, the intellectual subjects that a governess taught varied according to knowledge and education of the governess. The higher the class status of the family, the more accomplished they expected their daughters to become. Therefore, wealthier families hired more accomplished governesses, though they might additionally supplement a governess's knowledge with specialized instructors, especially of music and dance. Yet skill and knowledge were not the only qualities parents were counseled to examine in a potential governess. Gisbourne advised his readers to choose a governess who was not only a qualified teacher but also of good character: "To meet with a person tolerably qualified as to mental accomplishments, is sometimes not an easy task. But to find the needful accomplishments united with ductility, with a placid temper, and with active principles of religion, is a task of no small labor" (387).

Although moral values and intellectual skills were important components of female education, the focus on marriage as the aim for young women resulted in an emphasis on certain socially mandated skills that were expected to attract suitors. According to Alice Renton, a governess taught her female pupils "one or two languages, preferably French and Italian, music, dancing, drawing and needlework. .. . The eventual aim was the best possible marriage for her pupils" (48). In Pride and Prejudice Caroline Bingley defines her "idea of an accomplished woman": "A woman must have a thorough knowledge of singing, drawing, dancing, and the 
modern languages, to deserve the word; and besides all this, she must possess a certain something in her air and manner of walking, the tone of her voice, her address and expressions, or the word will be but half deserved" (29). The definition of an "accomplished" woman was apparently under debate in the period, since Darcy (partly as a compliment to Elizabeth who is reading at the time and reflecting the title of Hester Chapone's conduct manual) adds to Miss Bingley's list “the improvement of her mind by extensive reading," and Agnes Porter included scholastic disciplines such as English, history, and geography in the education of her pupils, which Miss Bingley omits from her list. Yet despite the claim that female education should improve the mind, because marriage remained the primary justification for female education, much of that education focused on artistic accomplishments. When Porter prepared to leave her second employer, Lord Ilchester, she reflected in her journal: "The two eldest [daughters] were married, the third to be presented this spring. Towards them I had performed the part assigned to me" (173). Thus, the governess was expected to educate her female charges in the qualities that would enable them to attract appropriate husbands and occupy the idle hours they possessed as women of the leisure class. The accomplishments of music, drawing, and dancing marked the woman's class status. She had time to focus on such activities because she did not have to learn a trade or occupation. However, the emphasis on leisure-time activities neglected the practical skills that a woman needed to run a household and rear children, as well as the intellectual skills she needed to be good companion to her husband and an able teacher to her children. Yet if female education focused on these intellectual skills, a governess would become unnecessary. Thus, the contradiction in female education leads to the failure of the governess - a failure evident in both Camilla and Emma — and of marriage ideology and class ideology. 
The incongruence in the governess's occupational description did not end, however, with conflicting skill sets that she should teach her pupils. The basic expectation that she would prepare her female pupils for marriage, however that preparation was defined, reveals a faultline in the courtship ideology of the leisure class. As Peterson writes, "such employment was, in fact, an aggravation of her incongruent status. While employment in a middle-class home was intended to provide a second home for the governess, her presence there was evidence of the failure of her own middle-class family to provide the protection and support she needed" (15). Educated women from the leisure class had few choices of occupation if they did not marry. Wollstonecraft addresses this problem in Thoughts on the Education of Daughters: "But many who have been well, or at least fashionably educated, are left without a fortune, and if they are not entirely devoid of delicacy, they must frequently remain single. Few are the modes of earning a subsistence, and those very humiliating" (25). Wollstonecraft lists three possible employments, which all focus on the traditionally female role of caregiver, and she finds them all demeaning: a "humble companion to some rich old cousin, or what is still worse, to live with strangers, who are so intolerably tyrannical, that none of their own relations can bear to live with them"; a "teacher at a school [which] is only a kind of upper servant, who has more work than the menial ones"; and a "governess to young ladies [which] is equally disagreeable" (25). By the latter part of the long eighteenth century, many leisure-class women also supported themselves by writing, but doing so could not guarantee a steady income the way that the occupations in Wollstonecraft's list could. ${ }^{8}$ In The Wrongs of Woman (1798) Wollstonecraft further identifies the position of governess as "the only one in which even a well-educated woman, with more than ordinary talents, can struggle for a subsistence; and even this is a dependence next to menial" (141). As a governess, "a well-educated woman" gave her pupils an education similar to the one 
that she had received, though the best governesses worked to maintain their proficiencies and keep up to date on the latest pedagogical concepts. For example, Agnes Porter studied Italian and German, and she read the Edgeworths' Practical Education (1798), commenting that "[b]etween theory at night and practice all day, I should do something" to educate her pupils (210). Yet the failure of the governess's own education to make her successful on the marriage market signaled the instability of both courtship and class ideologies. The ideological emphasis on female accomplishments as the key to success on the marriage market covers over the fact that marriage in the period was ultimately a numbers game that had nothing to do with a young woman's education. The gender imbalance in England meant that not all women could marry, but a woman's chances increased with the size of her dowry, which ultimately was a matter of circumstances that were largely out of her control.

Nevertheless, marriage ideology asserted that an accomplished young woman must find success on the marriage market because being a wife was considered the only proper role for leisure-class women. However, the ideology also maintained that a similarly accomplished woman must prepare a girl for the marriage market (since an unaccomplished woman would have been unable to teach what she did not know), and because of class imperatives, the governess, rather than the mother, performed this duty. Thus, as a leisure-class woman whose preparations for the marriage market and economic comfort had failed, the governess represented a rupture (a failure made ironically necessary by the higher ratio of women to men on the marriage market) in both courtship and class ideologies. Although in her position as governess she was training other leisure-class girls for the marriage market, there was no guarantee that these efforts would be any more successful than her own. Although the governess drew attention to the instability of courtship and marriage ideological formations, an instability that eighteenth- 
century economics and gender distribution did nothing to lessen, she was simultaneously required to minimize that faultline by continually reproducing courtship and marriage ideology by indoctrinating the next generation. As Sinfield explains, "Despite their power, ideological formations are always, in practice, under pressure, striving to substantiate their claim to superior plausibility in the face of diverse disturbances. Hence ... ideology has always to be produced" (41). Despite the governess's failure to fulfill the ideology by marrying, she had, for her own material survival, to pass on that ideology to her pupils. Thus, because her very existence posed a threat to the plausibility of leisure-class courtship and marriage ideologies, society required that the governess cover over the ideological faultlines by continually reproducing that ideologyand those around her also sutured over the faultlines by emphasizing the governess's contribution to the ideology, rather than her personal failure to fulfill it or that success may have been beyond her control. Thus, the governess was generally discussed as an educator rather than as a spinster, though both labels could have applied to many governesses.

\section{"But Nominally a Tutress": The Governess's Failure as Dissent in Camilla}

Margaret Anne Doody points out that Frances Burney's Camilla has historically been read as "a story about ... female education" (206). Although she argues that such a view is limiting and not entirely correct, she also notes that the "tempting subtitle, A Picture of Youth, appears to announce an education book. ... Readers have always been partly right, indeed in thinking the novel is an "education book" (206). Yet, in a novel that is at least partially about female education, the role of the governess has long been overlooked, demonstrating that readers too can be complicit in replicating ideology. The short history of Miss Margland that the narrator provides bears close examination, because it is typical of governesses in the period: "Miss Margland was woman of family and fashion, but reduced, through the gaming and 
extravagance of her father, to such indigence, that, after sundry failures in higher attempts, she was compelled to acquiesce in the good offices of her friends, which placed her as a governess in the house of Sir Hugh" (45). After failing on the marriage market ("higher attempts")—-whether because of lack of fortune, beauty, education, character, or all four is not completely clear-Miss Margland is reduced to becoming a governess to Camilla's cousin, Indiana Lynmere, though, unlike many governesses, she benefits from having "friends" who can help her find such a suitable position.

The plot of the novel focuses, of course, not on Miss Margland, but on the three Tyrold sisters and their cousin Indiana. Only Eugenia Tyrold, as Sir Hugh's heir, has any expectation of large fortune. Mr. Tyrold has saved a small inheritance for Eugenia’s sisters Lavinia and Camilla, and their cousin Indiana has her own relatively small fortune of $£ 1,000$. Though this fortune is larger than most Austen heroines possess, Miss Margland views it as insufficient to attract the aristocratic husband she desires for Indiana. With the reckless spending of Lionel and Clermont destroying the family estates, however, the threat of complete financial ruin is a very real one for the Tyrold clan. The young women must marry or face the risk of working, probably as governesses. Yet this risk of female work is never directly addressed in Camilla. The title character's innocence requires a certain degree of ignorance about finances that Burney demonstrates through Camilla's inadvertent debts, her extreme guilt over her small debts, and her focus on leisure rather than work. Rather than leading to employment, financial ruin during the course of the novel results in imprisonment and madness. ${ }^{9}$ The young women of the novel never labor for wages, because they are involved in the difficult work of courtship. This is the work that a governess is expected to prepare her pupils for and guide them through. Miss Margland is the only governess in the novel, and in this role she fails spectacularly. Reflecting 
her own limited education and weak character, Miss Margland fails to properly educate Indiana, whose intellect and character are both woefully lacking, and then she fails to promote a proper courtship for her charge. With this subplot, the novel inquires: as a representative of the failure of the courtship system as well as the system of female education, how can the governess do anything other than fail to fulfill these aspects of her role? In the flawed courtship and marriage systems, the governess, because she represents both ideological failure and ideological alternative, opens space for dissent from the ideology. Her failure indicates serious problems with the social system and emphasizes the difficult work that courtship requires. If the governess fails, as Miss Margland does, then the entire ideological system is in jeopardy. Yet although Miss Margland fails Indiana, as well as the Tyrold sisters, all four young women make appropriate marriages by the novel's conclusion. Thus, the novel attempts to make the governess's failure irrelevant. However, as I discuss later in this chapter, the continuation of the system through these marriages seems forced rather than natural as all four young women in the family suddenly find appropriate spouses just in time for the novel's conclusion (the final chapter is especially rushed). This awkward and unnatural conclusion, rather than demonstrating a triumphal reassertion of the status quo, cannot fully erase the space for dissent that the role of the governess inevitably creates.

In Burney's novel, the governess passively opens space for dissent by embodying both individual and ideological failure. Miss Margland's personal failure as a governess begins with her unsuccessful education of Indiana: “To Indiana, however, she was but nominally a tutress; neglected in her own education, there was nothing she could teach, though, born and bred in the circle of fashion, she imagined she had nothing to learn" (45). Here the narrator notes the interdependent relationship between teaching and learning, a relationship that Agnes Porter, 
among other educators who studied as well as taught, understood. Miss Margland's failure to recognize the importance of teacher education mirrors her failure to recognize how poorly she is educating Indiana. Yet despite the education Miss Margland received in her own youth, the narrator blames money, rather than education or character, for her failure on the marriage market. Thus, Miss Margland's shoddy education is important only because she fails on the marriage market and must become a governess and transmit her ignorance to the next generation.

Because she is relying heavily on Indiana's physical beauty to attract a wealthy husband, Miss Margland's plan for Indiana's education contains only "a little music, a little drawing, and a little dancing; which should all . . . be but slightly pursued, to distinguish a lady of fashion from an artist" (Burney 46). This attitude reveals another contradiction in the role of the governess. As noted earlier, a young woman of the leisure class was educated to possess certain accomplishments: music, dancing, drawing, needlework, and perhaps some French. Yet she was expected not to master any of these skills, because doing so would put her in the position of "an artist," one who performs, or even could perform, in public to make a living, a distinctly ungentlewomanly activity in eighteenth-century England. Yet the governess, who failed to marry, found herself in the very position of turning her amateur accomplishments into a profession. While writing Camilla, Burney may have been observing her sister Esther's own conflict between amateur accomplishments and professional performance as struggled against using her musical talent professionally, both for private teaching and for semi-public performance. Three years after the publication of Camilla, Esther's financial need became so great that she finally began giving private music lessons to supplement her family's income. ${ }^{10}$ The governess's contradictory status between amateur and professional was elided in several ways: the governess's work was domestic and therefore private rather than public; the governess 
was expected to teach her pupils only amateur-level proficiency; and specialized instructors (a dancing master, for example) were hired to fill in gaps in the governess's teaching ability but still provide the pupil with only amateur-level skill.

Thus, Miss Margland's limited instruction in accomplishments does not significantly injure Indiana. Lack of skill was expected in female accomplishments, but Miss Margland's failure to teach Indiana to think for herself is a serious gap in her education that does threaten Indiana's happiness, well-being, and reputation: "Indiana thought so little for herself, that she adopted, of course, every opinion of Miss Margland” (206). Whether Miss Margland enjoys maliciously manipulating Indiana, or she merely fails to teach Indiana to think for herself because Miss Margland herself lacks critical thinking skills, she nevertheless fails to prepare Indiana for adulthood and thus fails to fulfill the goal of true education. Throughout the novel Indiana is perpetually infantilized by mimicking Miss Margland's desires instead of developing her own. Indiana wants to marry Edgar because her governess wants her to, and after her marriage to Macdersey she invites Miss Margland to live with her because she is "so accustomed to her management" that she cannot function with her (909). Of course, Miss Margland works to make herself indispensable to Indiana so that she will not need to find a new governessing position once Indiana marries; she can simply continue function as Indiana's advisor, if not her governess. Miss Margland's failure to teach Indiana to think for herself directly leads to Indiana's elopement with Macdersey. Miss Margland's failure as an educator is in part a critique of her individual character, since her weak character makes her a poor teacher. However, because her education is largely to blame for her moral development, her character itself critiques the ideology that suggests she is an appropriate person to help young women prepare for and navigate the marriage market. Furthermore, by putting poorly educated women in charge 
of educating the next generation of women and preparing them for marriage, the ideology exposes its own faultline. In addition, the governess's own survival may require perpetual infantilizing her charges, which undermines both her stated goals and marriage ideology.

Although she largely fails as an educator, Miss Margland does attempt to fulfill her role as governess successfully, as her determined efforts at marrying off Indiana demonstrate. Once Indiana reaches marriageable age, Miss Margland begins harassing Sir Hugh "daily . . in proposing a journey to London, an indispensable duty, that the young ladies should see and be seen, in a manner suitable to their situation in life" (53). She correctly recognizes that such a journey is appropriate. After all, if Indiana and her cousins are going to marry, they must first find husbands, and London, as the social center of England, was one of the primary places for young women to do exactly that. Yet Miss Margland initially fails to overcome Sir Hugh's "fixt aversion to London, and to all public places," and to convince him to accept her proposal (53). Even though circumstances eventually allow her to take her charge to Southampton and London, Miss Margland's efforts are not entirely selfless. She wants to marry off Indiana because she "languishe[s] to quit Cleves" (154). She finds country life dull and longs to return to the city: "Miss Margland, equally void either of taste or of resources for the country, had languished and fretted away twelve years in its bosom, with no other opening to any satisfaction beyond a maintenance, except what she secretly nourished in her hopes, that, when her beautiful pupil was grown up, she should accompany her to the metropolis" (53).

Her efforts to marry off Indiana reflect not only her desire to leave the estate at Cleves but also her enjoyment of the power she experiences in the orphaned Indiana's courtship, especially since Sir Hugh's incompetence as a guardian creates a vacuum that she is more than happy to fill. The see-saw incident that leaves Eugenia crippled demonstrates Sir Hugh Tyrold's 
incompetence in raising children, yet Clermont and Indiana have been left to his care. As a bachelor he lacks a clear understanding of courtship and marriage, especially as it has evolved by the end of the eighteenth century, and while he expects to arrange the marriages of his nephew and nieces, he lacks the ability to do so. Ironically, however, society expects that a spinster governess will possess the necessary understanding of courtship and marriage, and thus, Miss Margland steps into the void left by Sir Hugh to promote the match between Indiana and Edgar, and signs of its failure threaten to reduce her household power: "Sir Hugh had almost thought her accountable for the slowness of Mandlebert's proceedings. To keep up her own consequence, she had again repeated her assurances, that all was in a prosperous train" (154). Miss Margland's concern about "her own consequence" above the actual progress of the courtship reveals that her efforts to find Indiana a husband result more from her personal needs and desires than from a commitment to fulfill the role of the governess to her charge.

When Miss Margland realizes that Edgar may not be interested in marrying Indiana, she feels upset not so much at the loss of Edgar as she "feared losing all weight both with the baronet and with Indiana" (156). After all, for Miss Margland, and thus also for Indiana, marriage is not about the man, but his position and the successful completion of courtship narrative. As a governess, Miss Margland attains social significance only through Indiana, and the higher the wealth and class of Indiana's husband, the higher the status and achievement Miss Margland believes that she will gain, both vicariously through Indiana and personally for making the match. When Indiana considers marrying Edgar, she desires the match for the material objects that he owns: "She even wished to refuse him:--but Beech Park, the equipage, the servants, the bridal habiliment.--No! she could enjoy those, if not him. And neither her own feelings, nor the lessons of Miss Margland, had taught her to look upon marriage in any nobler point of view" 
(206, emphasis added). By instilling in Indiana the same mercenary view of marriage that she possesses, Miss Margland exposes the mercenary nature of the marriage system that it is her role to suture over — with both the traditional ideology of religious imperative for marriage and the newer ideology of romantic love. Miss Margland views Indiana's marriage as a means to an end, and she instills the same attitude in her pupil. Although Miss Margland will never fully regain her former social status, both governess and pupil view marriage as their only means for climbing the social ladder. Since this was largely the reality for women of the late eighteenth century, Miss Margland realistically educates Indiana, but in doing so, Miss Margland fails to fulfill the ideological impetus of her position and simultaneously, though unintentionally, reveals faultlines in that ideology. Thus, courtship and marriage ideologies ignore, and attempt to cover over, the circumstances that make it difficult, even impossible, to fulfill, and Miss Margland's pragmatic efforts to promote a marriage for Indiana reveal this conflict.

No matter how tainted by ulterior motives, however, Miss Margland's efforts to marry off Indiana are impeded by her own incompetence. This ineptitude results largely from her poor judgment of character, which is attributed to her education, and also reflects her own failure on the marriage market. Because of this inadequacy, she cannot help Indiana, or her cousins, accurately evaluate potential suitors. She first views Frederic Melmond as "only a poor strolling player" (103). She initially assesses the foppish Sir Sedley Clarendel as "some Irish fortunehunter, dressed out in all he was worth; and charged Camilla to take no manner of notice of him" (67). Although he has faults and repeatedly stalls the courtship narrative of Camilla and Edgar, Sir Sedley is far from a fortune-hunter. In fact, he reverses the eighteenth-century British custom of dowry and instead attempts to pay a bride-price of $£ 200$ to Lionel for Camilla. Miss Margland's first impression of Alphonso Bellamy, the true fortune-hunter in the novel, is equally 
erroneous: "There! . . that gentleman is completely a gentleman. I saw it from the beginning. How different to that impertinent fop [Clarendel] that spoke to us just now! He has the politeness to take out Miss Eugenia, because he sees plainly nobody else will think of it, except just Mr. Mandlebert, or some such old acquaintance" (68). Although Miss Margland is not the only character who initially misreads Bellamy, she remains deluded by him long after the others, even the slow-witted Sir Hugh, have become suspicious of his unrelenting attentions to Eugenia. Miss Margland's inability to read Bellamy accurately contributes to his establishing a relationship with Eugenia that will result in her kidnapping and forced marriage.

Miss Margland's ineptitude at reading character complicates her efforts to promote a successful courtship for Indiana. Even from the beginning, this failure is not for lack of trying. Prevented from taking her charge to London, she determines to show off the beautiful Indiana at a local country ball instead. On this occasion the governess performs her duty of promoting marriage by advising Indiana on attracting Edgar's attention at the ball: "Miss Margland assured her, that now was the moment for fixing her conquest of Mandlebert, by adroitly displaying to him the admiration she could not but excite, in the numerous strangers before whom she would appear; she gave her various instruction how to set off her person to most advantage" (58). To some degree, Miss Margland correctly recognizes the power of a ball to promote a courtship. The narrator informs the reader that dancing with Indiana does elicit Edgar's admiration: "From the time of his first boyish gallantry, on the ill-fated birth-day of Camilla, Indiana had never so much struck young Mandlebert, as while he attended her up the assembly-room" (63). Yet at the same event, Edgar looks at Camilla with "real admiration" (64) because of her generous actions, which Edgar values much more highly than Indiana's beauty. Thus, Miss Margland misreads Edgar's character, his admiration, and how to retain his attention. 
Her inability to read character accurately also reduces the efficacy of Miss Margland's use of speech to promote Indiana's courtship. Julia Epstein notes that the governess is "a talker when rhetorical manipulation can work to her advantage” (140). Yet Miss Margland's "rhetorical manipulation" does not always succeed because she lacks audience awareness. Because Miss Margland narrow-mindedly views the marriage market as a zero-sum game, in which all courtships that do not include Indiana must therefore divert attention from Indiana and impede her courtship, she uses her speech successfully to disrupt these other courtships. She still fails, however, to use her speech productively to promote a marriage for Indiana, as her attempt to manipulate a courtship between Edgar and Indiana by initiating a rumor of their engagement backfires. At first the strategy seems to be successful, when Sir Hugh's servant Jacob brings a report that other people in the neighborhood believe that Edgar and Indiana are engaged. For Miss Margland, this report indicates success: "Miss Margland raised her head triumphantly. This was precisely such a circumstance as she flattered herself would prove decisive" (205). She determines to help the report "prove decisive" by using it as leverage to force a proposal from Edgar:

Miss Margland ... began now to pour forth very volubly, the most pointed reflections upon the injury done to young ladies by reports of this nature, which were always sure to keep off all other offers. There was no end, she said, to the admirers who had deserted Indiana in despair; and she questioned if she would ever have any more, from the general belief of her being actually pre-engaged.

Although Miss Margland is right that "reports of this nature" can cause "injury . . . to young ladies," any injury to Indiana in this case would, of course, be of her own doing. Furthermore, 
Miss Margland again misreads Edgar, and he decisively denies any romantic intentions toward Indiana, thereby foiling the governess's plan. In fact, since Miss Margland forces him to take a stand, he permanently ends any hope of a match between himself and Indiana. Since she has successfully manipulated Sir Hugh, Indiana, Camilla, and others for years in small matters, Miss Margland fails to realize that not everyone can be controlled by her use of language, especially regarding life decisions.

At Southampton Miss Margland continues to misjudge courtship. She expects that at this popular resort town Indiana will finally meet an appropriate suitor who will desire her beauty without minding her lack of fortune or intellect. The first reaction to Indiana seems to confirm Miss Margland's anticipation: "no other name was heard but Indiana Lynmere, no other figure was admired, no other face could bear examination" (747). However, this admiration remains the only success that the Southampton excursion affords Indiana and Miss Margland: they "soon found that the overtures of eyes were more ready than those of speech; and though one young baronet, enchanted with her beauty, immediately professed himself her lover, when he was disdained, in the full assurance of higher offers, and because a peer had addressed himself to Eugenia, she saw not that he was succeeded by any other" (747). The status-hungry Miss Margland needs her pupil to make the most advantageous match among the cousins, who seem to be the only young women on the marriage market in their Hampshire social circle, or at least the only ones who matter to the short-sighted governess. If a nobleman demonstrates interest in Eugenia, then Miss Margland must find a nobleman for Indiana. However, Indiana's beauty and $£ 1000$ are not enough to interest a nobleman, so Miss Margland never arranges a successful courtship for Indiana. Since the reality of Indiana's marriage prospects do not align with what Miss Margland desires for her charge, the governess and her charge find themselves unable to 
navigate the marriage market successfully. Ultimately, Miss Margland is removed from marriage negotiations entirely. Indiana's engagement to Melmond is orchestrated by Eugenia, and her elopement, which is eventually accepted by the family thanks to Camilla and Lord O'Lerney, is Indiana's one moment of independence from Miss Margland, as she chooses to follow Macdersey's desire without asking for her governess's advice.

As Miss Margland fails to promote a successful courtship for Indiana, so too she falls short as a governess by impeding the courtship prospects of Camilla and Eugenia, because of her misguided zero-sum game approach to the marriage market. Although Miss Margland is Indiana's governess, she is generally viewed as the governess of the Tyrold sisters as well, since they spend so much time at Cleves. Since she can increase her status only through Indiana's marriage, she disrupts Camilla's and Eugenia's courtships in an attempt to make Indiana's marriage even more unique and noteworthy, believing that a lack of courtships for the Tyrold sisters will result in a better courtship for Indiana. Because her history gives her a narrow view of the world and the marriage market, she sees the competition for a husband as particularly intense, especially when she is confined to the Hampshire social circle and Edgar presents the only socially appropriate match for Indiana. Miss Margland repeatedly disrupts the courtship of Camilla and Edgar, even after it is clear that Edgar will not marry Indiana. She makes a point of telling Edgar that Camilla is visiting Mrs. Arlbery despite his disapproval (353-54), and she interrupts the pair at Etherington (236-37) and at Southampton (641-42). At the resort town Miss Margland also impedes Eugenia's possible success in courtship when she reveals Eugenia's lessons with Dr. Orkborne: "This, shortly, made Eugenia stared at still more than her peculiar appearance.... [T]he beaux contemptuously sneering, rejoiced she was too ugly to take in any poor fellow to marry her" (748). Miss Margland disruption of Camilla's and Eugenia's courtship 
prospects reveals the conflict when the role of governess overlaps with that of the chaperon. By attempting to balance these two roles, Miss Margland finds herself caught in yet another contradiction: as Indiana's governess, her duty is to focus all her energy on promoting Indiana's courtship; as chaperon for all the cousins, she is expected to promote courtship for all the young women in her care. Because of her selfish motives, Miss Margland unsuccessfully negotiates this ambiguity, failing to promote a successful courtship for Indiana and also actively damaging the courtships of Camilla and Eugenia.

Miss Margland's failures result not only from misjudgment but also from selfcenteredness; she thinks of herself before her charges, so that she puts at risk the young women she is expected to protect. In fact, because her own identity is predicated on her relationship with her charges, especially Indiana, even when she is thinking of them, she is ultimately thinking more of herself. During the affair of the mad bull in the churchyard, for example, Miss Margland, focusing on her own safety from the bull, allows the fortuneless Melmond to woo Indiana and the fortune-hunting Bellamy to infiltrate the party. Sir Hugh finally questions her about the "two young gentlemen, that I never saw before," and in her answer Miss Margland ignores her duty to protect her charges and instead focuses on Melmond's attention to her: "“As to that gentleman, sir,' she answered, bridling, 'who was standing by me, he is the only person I have found to protect $m e$ "' (144, emphasis added). Though her own safety is important to her ability to protect her charges, she recklessly and without suspicion finds safety in relatively unknown men who present danger to the young women. Although in this event, no immediate danger comes to Indiana and her cousins, later Miss Margland's selfishness poses a more serious threat to Camilla's well-being. Camilla asks Miss Margland to accompany her from London to Winchester, where her father has been imprisoned: "But Miss Margland, though she spared not 
the most severe attacks upon the already self-condemned and nearly demolished Camilla, always found something relative to herself that was more pressing than what could regard any other, and declared she could not stir from town till she received an answer from Sir Hugh" (824). Miss Margland's impractical abuse of protocol and her refusal to accompany Camilla results in the heroine's inappropriately unchaperoned stay at the inn and her descent into illness and madness. These effects nearly cost Camilla her health, her sanity, her reputation, and her eventual marriage to Edgar.

Most seriously, however, Miss Margland's inattention to her charges allows two elopements. So wrapped up in her own concerns, she does not even recognize the danger that Bellamy and Macdersey pose to her charges, and thus she does not anticipate, let alone work to prevent, these elopements. First, she becomes separated from Eugenia and Bellamy at the opera, which gives Bellamy the opportunity to kidnap Eugenia and force her to marry him in Scotland. Then, Miss Margland pays so little attention to Indiana and her growing attachment to Macdersey, that she fails to avert their elopement. In both of these situations Miss Margland self-centeredly attempts to impose her preferred narrative rather than reading the evidence to discern the narrative that is actually unfolding. Although both stories eventually are resolved satisfactorily_Bellamy accidentally shoots and kills himself, and Camilla and Lord O’Lerney make certain that the Macderseys have an adequate income - these resolutions, fantastic though they are, are accomplished without Miss Margland's aid. Instead of protecting her charges, she allows dramatic dangers to threaten and injure them.

As the guardian of a faultline in courtship and marriage ideology, the governess has an important role in society. Yet ironically, Miss Margland seems unaware of her ideological importance. When Dubster tells her that Lionel said she was "vast fond . . of matrimony," she 
replies, "Matrimony? what have I to do with Matrimony?" (587). Although Miss Margland may be disingenuous here, she also does not seem to be fully aware of her importance to courtship and marriage ideology, an ironic ignorance, considering her continual concern about her own status as defined by courtship and marriage ideology. The answer to Miss Margland's question, as the novel implies, is "Everything, and nothing at all." Ultimately, Miss Margland signals the useless position of the governess in society. She is the extra woman who cannot be recuperated into marriage narrative and who cannot even assist courtship narrative. Although Miss Margland never consciously critiques courtship and marriage ideologies, her behavior as a governess reveals the obstacles to succeeding at courtship narrative and the disjunction between theory and practice, ideology and reality. The narrative of Camilla reveals the work that courtship requires, and Miss Margland, instead of easing that work for the young women, further complicates it. Miss Margland's colossal failure seems to put the system of patriarchal courtship and marriage in jeopardy. Yet despite the ideological danger presented by the governess's failure, by the ultimate end of the novel, all the young women of the Tyrold family become appropriately married: Lavinia to Hal Westwyn, Camilla to Edgar, Eugenia to Melmond, and Indiana to Macdersey. Yet some of these marriages stretch plausibility. Hal Westwyn, at the suggestion of his father, suddenly transfers his affection from Camilla to Lavinia upon meeting the older sister, and they become engaged the same afternoon. The Tyrold family accepts the hasty proposal with odd composure: "Sir Hugh received the proposition with the most copious satisfaction; Mr. and Mrs. Tyrold with equal, though more anxious delight; and Lavinia herself with blushing but unaffected hopes of happiness" (905). Although Mr. and Mrs. Tyrold experience a bit of parental anxiety, no one expresses astonishment or concern at the suddenness of the proposal. As Lavinia passively accepts the proposal, Doody notes, “[p]oor Lavinia Tyrold is given no love 
story of her own" (240). Although Melmond's proposal to Eugenia takes more time than Westwyn's to Lavinia, it represents a complete reversal of his previous feelings as he now "fearfully sought the favour he before had reluctantly received" (912). Despite the questionable plausibility of some of these marriages, the narrator insists that they are happy unions. Indiana's elopement has a favorable outcome: "Indiana was more fortunate in her northern expedition, than experiments of that nature commonly prove" (908). Hal Westwyn is Lavinia's “deserving partner," and "she grew daily upon the esteem and affection of her new family" (909). Melmond does not regret the loss of Indiana, and his new love for Eugenia is lasting as "reason and experience endeared his ultimate choice. Eugenia once loved, was loved forever" (912). And despite Edgar's rather "priggish" behavior (Straub 186), the narrator asserts that his marriage to Camilla is "exquisite" (913). Thus, the marriage system continues, but its perpetuation seems not natural but forced, and this in turn reveals in unnaturalness of the ideology itself. The concluding marriages attempt to cover over the ideological faultline, but their unnaturalness only call attention to the problems inherent in eighteenth-century marriage ideology. Marriage is, of course, the conventional way to conclude a comedy, and more specifically a courtship novel, and the marriages at the end of the novel met the conditions of plausibility for an eighteenth-century audience. Nevertheless, the dissatisfying character of the marriages at the end of the novel in itself calls into question both the convention of using marriage to conclude a comedy and the ideology of marriage. As Sinfield argues, "Readers do not have to respect closures" (48). We do not have to accept that the marriages that conclude Camilla successfully reassert courtship and marriage ideologies. Instead, our dissatisfaction with the conclusion of Burney's novel opens space for ideological dissent. 


\section{"Less as a Governess than a Friend": The Governess's Work as Dissent in Emma}

In Emma, Austen considers the role of the governess as an alternative to that of the wife, rather than merely as a means of critiquing courtship and marriage ideology. While the ideology that propels the action of Emma is the belief that marriage is the only proper position and the only appropriate "work" for leisure-class women, the ideology of the novel is not that simple. As Sinfield points out: “Any position supposes its intrinsic opposition. All stories comprise within themselves the ghosts of the alternative stories they are trying to elude" (47). After all, even Emma's own ghost story becomes real as she finds herself becoming a wife at the end of the novel, despite her assertions at the beginning of the narrative that she will never marry. Miss Bates represents another ghost story that Emma overtly denies, but still must address as she asserts to Harriet why she could never be like Miss Bates even if she does not marry (84-85). In addition, Jane Fairfax's story serves as an important foil to Emma's story. Jane's position as an economically disadvantaged but well-bred young woman of the leisure class signals faultlines that threaten both the plausibility of marriage as the preferred option for leisure-class women and the definition of leisure-class woman. Although she is more skilled than Emma in the leisureclass female accomplishments of the time, Jane's lack of finances hinder her success on the marriage market. The novel negotiates this faultline in leisure-class ideology by opening up a discussion of an alternative position for women - the governess - only to attempt to erase this position and elide faultlines in both marriage and class ideologies through the marriages of both Miss Taylor and Jane Fairfax.

The trace of female work that Jane and Mrs. Weston represent in Emma threatens both marriage and class ideologies as it calls into question the social rules of marriageability and of social interaction, while the marriages of both these characters serve to collapse the ideological 
binary between governess and wife. Although many literary critics have discussed Austen's class ideology in Emma, they have largely overlooked the role that the governess plays in the novel's examination of both class and marriage ideologies. ${ }^{11}$ Although the novel contains much discourse on the role of governess, it never shows this occupation in action, and instead subsumes the role into that all-important leisure-class role of wife. This method of negotiating the faultine serves both to present and to deny a theoretical alternative to the role of wife.

Emma opens with the marriage of Emma Woodhouse's former governess, Miss Taylor, to Mr. Weston. This marriage allows Miss Taylor to leave her professional position as a governess and to participate even more fully as a member of the leisure class than she had as Emma's governess. During the course of the novel several newcomers also enter the leisure-class society of Highbury: the vicar, Mr. Elton, marries Augusta Hawkins, a woman with clear social ambitions; Jane Fairfax comes to stay with her aunt and grandmother; and Mr. Weston's son, Frank Churchill, makes his first visit to his father's house. Because Highbury society does not know that Frank and Jane are secretly engaged, it attempts to interpellate Jane into the primary alternative role for economically disadvantaged leisure-class women: the governess. By the end of the novel socially appropriate marriages compose the society of Highbury: the Westons, the Eltons, Frank and Jane, Emma and Mr. Knightley, and Robert Martin and Harriet Smith. Two of these matches - the Westons and Frank and Jane — serve to collapse the binary between governess and wife. Because the governess (or potential governess) becomes the wife, the two positions cannot be mutually exclusive. As demonstrated in the remainder of this chapter, this collapse in turn calls into question both marriage and class ideologies.

As already noted, the governess embodied the contradiction of an employed gentlewoman, and she also possessed ambivalent authority. In fact, the governess's failure to 
acquire enough maternal authority could undermine her ability to educate her charges appropriately. In the Woodhouse home Miss Taylor illustrates this danger because she occupies the position of a friend rather than an authority figure to her charges, especially Emma: "Sixteen years had Miss Taylor been in Mr. Woodhouse's family, less as a governess than a friend, very fond of both daughters, but particularly of Emma. Between them it was more the intimacy of sisters" (7). As Lenta explains, however, Miss Taylor's "special position in the family depends on the fact that Emma's mother is dead, leaving an empty space to be filled in the Hartfield family" (39). In this situation Miss Taylor has the opportunity for expanded authority to fill the gap left by the dead Mrs. Woodhouse, but instead she becomes more of a sister to the Woodhouse daughters. Miss Taylor was presumably quite young when she entered the Woodhouse home (since she is still young enough to reproduce when she marries Mr. Weston), which may have impaired her authority and fostered this sisterly friendship rather than parental relationship with Emma. After all, advanced age can acquire authority in a way that youth usually cannot, although the vexed nature of the governess position also inevitably forestalled her authority. Because the governess was particularly close to the family without actually being a member of the family, such an ambiguous position was not uncommon for a governess. For example, Agnes Porter also enjoyed a familial role in the household of Lord Ilchester, because Lady Ilchester was either ill or dead during Porter's employment. Porter later commented that she "had tried to supply to them [her charges] a mother's love" (173). Serving as a surrogate mother, however, expanded Porter's authority and influence, and aided her efforts to reproduce ideology in her pupils.

In Emma, however, Miss Taylor's sisterly (rather than motherly) relationship with Emma results in a breakdown of the governess's authority. After all, even an older sister is ultimately 
an equal and not an authority figure, since both sisters are under parental authority. Tony Tanner calls Miss Taylor Emma’s “(ungoverning) 'governess”” (179). When Mr. Knightley comments to Mrs. Weston that "ever since she was twelve, Emma has been mistress of the house and of you all," she replies: "I should have been sorry, Mr. Knightley, to be dependent on your recommendation, had I quitted Mr. Woodhouse's family and wanted another situation; I do not think you would have spoken a good word for me to any body. I am sure you always thought me unfit for the office I held" (36). Mrs. Weston reveals the self-awareness of her own failure as a governess that Miss Margland lacks, yet her failure is arguably less threatening than Miss Margland's. While Miss Margland's failure results from appalling incompetence, Miss Taylor's failure is a function her lack of authority. Thus, it is clear that Emma has learned from Miss Taylor — though perhaps not as much as she might have_—while Indiana remains ignorant. Miss Taylor's lack of authority results from her submissive personality and modesty, which Mr. Knightley notes when he states that she is "very fit for a wife, but not at all for a governess" (36). Once again the governess embodies an ideological contradiction: a woman must be submissive, but a governess (and a mother, for that matter) is expected to have enough agency to educate and rear children. While being a surrogate mother increased Agnes Porter's authority, being friends with her pupil diminishes Miss Taylor's authority.

Perhaps Miss Taylor's lack of authority resulted in a failure to properly indoctrinate Emma in the dominant ideology, and this may contribute to Emma's refusal to consider marriage, since she knows she is already wealthy and empowered as Miss Woodhouse of Hartfield at the beginning of the novel. Instead of learning to accept the role of wife, Emma may have ascertained the faultlines in marriage ideology, and thus she refuses to accept it. While Emma asserts that she has nothing to gain in terms of material comfort or social power from 
marriage, the ideology insists that the wife is a woman's God-ordained and society-endorsed role. For example, in his Letters to a Young Lady (1789), the Reverend John Bennett asserts that marriage is "the most natural, innocent and useful state," and that marriage "is, in some degree, a duty, which we owe to the world" (161). Although most women in the period, such as Miss Margland and Jane Fairfax, are not wealthy like Emma and thus can gain financial stability through marriage, which they have no other means of attaining, the ideology asserts that a woman should marry because it is her duty, not because she has something to gain, and Emma fails to accept this mandate. Though there is evidence in the novel that Emma possesses a willfulness and selfishness that would impede education, nevertheless the governess is expected to indoctrinate even a stubborn, rebellious, selfish, or otherwise difficult child. Because Miss Taylor does not succeed in indoctrinating Emma in marriage ideology, the responsibility of educating Emma to accept the role of wife falls to Mr. Knightley.

Miss Taylor's failure to indoctrinate Emma is further produced by the sororial model of living at Hartfield, which offers an alternative to marriage (similar to that illustrated in Sarah Scott's Millenium Hall), since Miss Taylor both lacks authority and seems invested in the sororial relationship herself, as it tempers some of the psychological difficulties of the governess experience for her. Miss Taylor and Emma's relationship even reverses the usual governesspupil dynamic; Emma has educated Miss Taylor for the role of wife rather than vice versa, as Mr. Knightley observes: "But you were preparing yourself to be an excellent wife all the time you were at Hartfield. You might not give Emma such a complete education as your powers would seem to promise; but you were receiving a very good education from her, on the very material matrimonial point of submitting your own will, and doing as you were bid" (36-37). Thus, the collapse of Miss Taylor's authority is complete. Although Emma clearly knows the 
ideology, as she demonstrates through her "education" of Miss Taylor, her refusal to accept marriage for herself and usurpation of the governess's authority indicate the failure of Miss Taylor to fulfill her expected role. In fact, Emma's training of Miss Taylor and her efforts to promote the marriage of her governess to Mr. Weston, places her in the role of pseudogoverness, and thus, this reasonably successful role-reversal functions as another explanation of Emma's resistance to courtship for herself. Although she appears to reject marriage ideology, she seems to accept the ideological binary separating the governess from the wife. Miss Taylor's failure to act as an authoritative governess, and the ideological challenge of that failure, are minimized, however, by Emma's eventual marriage to Mr. Knightley.

Miss Taylor's position as more of a sister than an authority figure to her charges thrusts her into a dependent, daughterly relationship with Mr. Woodhouse. He attempts to retain her as a single dependent in his household, referring to her throughout the novel as "Miss Taylor" rather than "Mrs. Weston," an infantilization that resists courtship and marriage ideology. A few hours after the Westons' wedding Mr. Woodhouse laments: “Poor Miss Taylor!—I wish she were here again. What a pity it is that Mr. Weston ever thought of her!" (10). Mr. Woodhouse has a childish resistance to change that is reflected in his opposition to marriage, which was expected to alter a woman's familial alliance from her own to her husband's family: "He was a nervous man, easily depressed; fond of every body that he was used to, and hating to part with them; hating change of every kind. Matrimony, as the origin of change, was always disagreeable; and he was by no means yet reconciled to his own daughter's marrying" (9). Mr. Woodhouse's resistance to marriage in some ways mirrors Emma's own resistance to marriage for herself, though, unlike her father, she readily works to promote the marriages of other people. Mr. Woodhouse's opposition to the marriages of those in his household becomes evident not 
only in his response to Miss Taylor's marriage, but also in his reaction to his daughter Isabella's marriage. He becomes depressed at "the idea of his daughter's attachment to her husband" (78), and he selfishly "could never allow for ... any body's claims on Isabella, except his own" (77). Other characters, especially Mr. Knightley, view Mr. Woodhouse's desire to keep Miss Taylor and Isabella in his household forever as the irrational and unnatural wish of a foolish old man who dislikes change, though they do not openly oppose his ideas or correct his continued references to "poor Miss Taylor," finding it simpler to ignore him. Yet although Mr. Woodhouse's attempts to keep Miss Taylor in his household are viewed as irrational by those around him, his treatment of Miss Taylor as a dependent rather than an employee contributes to her marriage, since she seems to be a marriageable young woman rather than a spinster governess. Thus, the binary of governess and wife is stronger when the governess is undesirable because of her age and personal qualities (one can hardly imagine anyone wanting to marry Miss Margland).

Despite the ideology of marriage for love, financial necessity also usually separated the woman who would become a governess from the woman who would become a wife. As already noted, from childhood Jane Fairfax is educated specifically for governessing, to provide her with "the means of respectable subsistence" (154), because she possesses a fortune so small that not only can she not live on it, but it is also viewed as insufficient for the marriage market. Thus, the "proper" role for Jane, according to those around her, is not wife, but governess. Not only does Colonel Campbell educate Jane for governessing, but Mrs. Elton, in all her plans for Jane's benefit, never considers finding Jane a husband, since everything about Jane's education and position in society marks her as a prospective governess rather than as a potential wife. For example, she has developed musical expertise in expectation of becoming an educator, rather 
than possessing the amateur ability demanded by courtship ideology. Only Mrs. Weston recognizes Jane's wifely qualities, perhaps because she herself was once a governess on the margins of the marriage market who succeeded in finding a husband. When Mrs. Weston suspects a match between Jane and Knightley, she finds evidence to support her suspicion: "I have heard him speak ... so very highly of Jane Fairfax! The interest he takes in her-his anxiety about her health—his concern that she should have no happier prospect! I have heard him express himself so warmly on those points! — Such an admirer of her performance on the pianoforte and of her voice!” (210). Yet Mrs. Weston is alone in her view of Jane as potential wife. When Emma tests Knightley's feelings toward Jane, he asserts that although she "is a very charming young woman," her reserve is an unacceptable "fault": "She has not the open temper which a man could wish for in a wife" (267). For Knightley, it is not Jane's position as potential governess but her personality that makes her ineligible for marriage, though, of course, Knightley is ignorant of the reasons for Jane's extreme reserve in Highbury. Unlike most members of his class, Knightley judges a woman's fitness for marriage by her character rather than her finances.

Later in the novel when Frank reveals his secret engagement to Jane, Mrs. Weston, who asserts that she has "always had a thoroughly good opinion of Miss Fairfax," comments to Emma, "It is not a connection to gratify" (375). Here Mrs. Weston seems to be using the term "gratify" specifically in the sense of "to oblige monetary expectations." Frank and Jane's marriage would have met disapproval from the snobbish Mrs. Churchill because of Jane's poverty, but Mrs. Weston still respects Jane's "steadiness of character and good judgment" (375). However, Jane's secret engagement to Frank calls into question that "good judgment" and consequently her fitness as a governess or a wife, given the impropriety of secret engagements, 
which circumvented courtship codes. However, Mrs. Weston, who is, as Claudia Johnson points out, ever forgiving of the faults of others, attempts to elide this lapse in Jane's judgment by remarking that the secret engagement is Jane's "one great deviation from the strict rule of right" (375). Jane admits to Mrs. Weston that she "can never be blameless. I have been acting contrary to all my sense of right; and the fortunate turn that every thing has taken, and the kindness I am now receiving, is what my conscience tells me ought not to be" (392). Yet, her ultimate marriage to Frank Churchill seems to erase this error of propriety from the minds of those around her and prevents her from becoming a governess.

Mrs. Weston's and Jane Fairfax’s marriages ensure their place in leisure class society, and such class status had real material implications for women in the period. Therefore, because of her liminal class status, the material conditions of a governess's employment became especially important, and she often struggled to maintain a level of material comfort as well as her social position. Agnes Porter ultimately left Lord Ilchester's household, for example, because of the material conditions of her employment. After Lord Ilchester married his second wife, Porter, who had enjoyed unusual independence after the death of the first Lady Ilchester, felt keenly the authority of the new Lady Harriot Ilchester, who emphasized Porter's inferior position by taking away privileges Porter had come to expect. After working for Lady Harriot for three years, Porter finally gave Lord Ilchester six months notice on March 28, 1797. Eight days earlier she had learned from Lady Harriot that "it was not intended that I should have a parlour in Town this year-this little circumstance determined my mind and fixed my conduct" (Porter 173). The loss of the parlor emphasized Porter's position as an employee and took away her privilege of participating in one of the primary pursuits of a gentlewoman in Londonentertaining callers. $^{12}$ 
Emma challenges the class ideology that places the governess in a liminal position by suggesting that she belongs completely within the leisure class. Unlike Agnes Porter's experience, the two governess characters in the novel participate in and enjoy the material conditions of Highbury's leisure class with little apparent anxiety displayed by the society, perhaps in part because Highbury is a small village with limited social options. The only character who implicitly questions the right of Mrs. Weston and Jane Fairfax to take part in the leisure class is the socially ambitious Mrs. Elton, who emphasizes their lower position even when she socializes with them. In order to allow the governess characters to join the leisure class, however, Austen must erase the active work of the governess in Emma by keeping working governesses out of the novel. Because Miss Taylor marries just as the action opens and Jane Fairfax never takes a governessing position, the reader never sees a governess at work. ${ }^{13}$ The governess joins a long list of working people who are missing in action in the novel. Although the novel repeatedly makes reference to working people and the work that they doWilliam Larkin is a bailiff, Robert Martin is a farmer, Mr. Perry is an apothecary, and Mr. Elton is a vicar - the reader never sees these men actively working in their occupations.

Instead, the novel focuses on the activities of the people of Highbury's leisure class, who never do any wage-earning work themselves (though some members of the leisure class do oversee their employees, as Mr. Knightley demonstrates when he speaks with William Larkin or Robert Martin). Their full-time job, as Jonathan H. Grossman points out, is maintaining proper etiquette. Thus, the novel is often read as the story of Emma's education in good manners. The marriages at the end of the novel "robustly represent the activity of a leisure class engaged in reproducing itself through proper conduct" (Grossman 157). In this key activity leisured women have an important role: "For Emma, as for most of Austen's unmarried female characters, 
choosing between matrimonial possibilities represents a career choice within the leisure class. In this sense Austen depicts Emma finding not just her proper place but also her work" (156). James Thompson further explains not only that Austen demonstrates that "courtship must involve some sort of work to develop affection and respect" (151), but also that "courtship and marriage remain the only real work open to women in this period and class" (152). Both Grossman and Thompson ignore the profession of the governess, presumably because it is not fully represented in the action of novel, yet this is the kind of work that Jane Fairfax fears she must find if Frank Churchill does not marry her soon enough, and which Miss Taylor escapes by marrying Mr. Weston. ${ }^{14}$ However, this occupation must be erased from the novel in order to maintain the imperative of the leisure class. Since the governess points to a faultline in leisureclass marriage and class ideologies, showing Miss Taylor or Jane Fairfax working as a governess could make their eventual marriages seem even more disruptive to the class structure, or make the marriages implausible to an early nineteenth-century audience. Yet the attempted erasure of actively working governesses in the leisure class world of Highbury only emphasizes the faultline in the ideological myth that the only plausible position and work for leisure-class women is the role of wife. Thus, because Mrs. Weston and Jane Fairfax participate in this leisure class during the action of the novel, they must forego working as governesses, and instead participate in the proper "work" for leisured women: marriage.

The attempted erasure of the role of the governess through marriage in Emma could be interpreted as a conservative maintenance of the ideological myth that well-educated leisureclass women always married. Austen's novels are rarely this simple and straightforward, however, and Emma is no exception. She identified with economically marginalized women, such as governesses, because she too was an unmarried woman, and without the support of her 
brothers after the death of her father, she too would have been looking for a situation as a governess or perhaps a lady's companion. Joanna Martin describes Agnes Porter as "the archetypal governess: the daughter of a clergyman who had no private income, she had to support herself and help her mother and sisters after her father's death" (Porter 2). Fortunately for Austen, also the unmarried daughter of a clergyman (and who, like Burney, never had a governess herself, though she attended school briefly), she had brothers to support her

financially. ${ }^{15}$ A series of tragedies, however, easily could have left her in Porter's position. Thus, one problem Austen addresses in Emma is what happens to women who are well-educated but lack dowries. Thompson points out that "marriage lies at the very heart of ideological contradiction in Austen's fiction, for it is both, at one and the same time, problem and solution" (155). By using the problem (contradictions in courtship and marriage ideologies) to create the solution (marriage of all the leisure-class women in the novel), Austen ultimately uses irony to negotiate the ideological faultline that the governess signals. In this way Austen calls into question the ideology of marriage for all leisure-class women, while still satisfying the expectations of her leisure-class audience and maintaining her own social position.

\section{Conclusion}

Since marriage was the institution through which patriarchy perpetuated itself, it was also the moment at which patriarchy could be challenged. The governess called into question courtship and marriage ideology in three ways. First, she represented one of the primary professional options for leisure-class women who could not or did not marry, and thus she proved that wife was not the only appropriate role for a leisure-class woman as the ideology claimed. In Emma, especially, Miss Taylor and Jane Fairfax each exhibit respectability and good manners as a governess and a prospective governess. Thus, the psychology of the leisure-class 
woman, rather than being limited to the role of wife, could be manifested in more than one role. Second, the governess prepared the next generation of women for marriage, but because she represented failure herself on the marriage market, she did not necessarily succeed. Miss Margland and Miss Taylor both fail, though in different ways, to prepare their charges for the marriage market. Finally, the governess took on some, though not all, motherly responsibility, and therefore she challenged the wife's childrearing role, complicated family dynamics, and even threatened her own effectiveness as an educator. Again, both Miss Margland and Miss Taylor complicate the relationships of the families for whom they work.

The governess characters in Camilla and Emma reveal the fantastical nature of courtship and marriage ideology in the period. The conflict between fantasy and reality is revealed in a society's secrets. In his book The Novel and the Police, D. A. Miller argues that some characters in Dickens' David Copperfield possess an "open secret," a "subjectivity [that] may be successfully concealed to other characters, [but] for us, the readers of the novel, the secret is always out" (205). Furthermore, the function of open secret demands that its knowledge be continually disguised: "Yet, curiously enough, the fact the secret is always known—and, in some obscure sense, known to be known — never interferes with the incessant activity of keeping it" (206). Not only do characters have open secrets, I would argue, but ideologies depend upon social open secrets as well, since "the social function of secrecy ... is not to conceal knowledge, so much as to conceal the knowledge of the knowledge" (206). In other words, the open secret works to hide the knowledge that people have knowledge that threatens the ideology. The open secret in the culture of marriage is that there are more women than men on the marriage market; therefore, all women cannot marry. Although this fact is known, it is not discussed, for it would undermine the ideology that requires women to marry. The result is not only that men maintain 
more choices in marriage but, more important, that women remain in competition with one another, instead of uniting and working together for social change. The governess, as the extra woman who cannot marry, epitomizes this open secret. While the faultlines the governess embodies open space for dissent from courtship and marriage ideologies, the attempted erasure of the faultlines in Camilla and Emma, try to keep this open secret, the knowledge of the knowledge that can so easily undermine the ideology, out of the social discourse. Yet attempting to deny the secret and uphold the ideology results only in what Miller refers to as a "fantasmatic recovery. In a mechanism reminiscent of Freudian disavowal, we know perfectly well that the secret is known, but nonetheless we must persist, however ineptly, in guarding it" (207). The novels conclude in fantasies that, rather than succeeding in covering over the ideological faultlines, are so clumsy at hiding the open secret that they ultimately draw attention to the problem of the governess, which Victorian writers will, finally, address more directly.

\footnotetext{
${ }^{1}$ The foremost study of the governess in England is arguably Kathryn Hughes' The Victorian Governess (1993). The most extensive studies of the governess in the eighteenth century that I have been able to locate are three chapters in Alice Renton's Tyrant or Victim?: A History of the British Governess (1991) and the chapters on Agnes Porter and Mary Wollstonecraft in Ruth Brandon's Governess: The Lives and Times of the Real Jane Eyres (2008). The chapters in Renton's book focus on the governess as purveyor of enlightenment notions of female education, and they largely ignore the governess's role in the broader culture as well as material conditions of her life. Brandon focuses on the specific experiences of individual governesses, whose selection she admits was "rather arbitrary" (2), and from this small sample she draws convincing, though limited, conclusions about the role of the governess, and more generally of women, in eighteenth- and nineteenth-century British culture.

2 "Governess." Oxford English Dictionary Online. 2007.

${ }^{3}$ Both Burney and Austen scholars not only often ignore the governess characters in these novels, but they also often overlook the problematizing of courtship and marriage ideologies that the novels reveal, even while they are analyzing the plots as courtship narratives. Critics of Camilla, such as Margaret Anne Doody, Joanne Cutting-Gray, and Julia Epstein, generally focus more on Mrs. Arlbery's mentorship of Camilla than on Miss Margland's supervision, even
} 
though Miss Margland spends much more narrative time with the heroine. Epstein briefly dismisses Miss Margland as "a talker" who is "manipulative and insecure" (140, 143). In Divided Fictions Kristina Straub does recognize the ideological contradiction in which the "system of power relations in society . . o ostensibly gives women a kind of ideological power through the institutions of romantic love and marriage," but simultaneously "contributes to women's ideological devaluation as passive, morally weak and sexually suspect objects in relation to male power" (183). However, Straub ignores how the governess reflects this ideological faultline, mentioning Miss Margland briefly as "Indiana's governess" who prevents Camilla from dancing with a man who has lost a glove (200). Janice Farrar Thaddeus, in Frances Burney: A Literary Life, lists the desires of a multitude of characters in Camilla, including characters as minor as Lord Valhurst, but she omits what Miss Margland wants: to help Indiana find a suitable husband and to leave the country and return to the city. Austen critics also tend to overlook the governess characters who appear in Emma and their ideological function. In The Proper Lady and the Woman Writer Mary Poovey, despite focusing on "the complex relationship between a woman's desires and the imperatives of propriety" in Austen's works, analyzes in detail only Lady Susan, Sense and Sensibility, Pride and Prejudice, Mansfield Park, and Persuasion, merely mentioning Emma in passing approximately half a dozen times. Traditionally critics who do examine Emma have focused on Emma's education through her experiences and Mr. Knightley's guidance, and such critics have seen her marriage as the logical conclusion of the novel. From this perspective, the heroine, rather than courtship and marriage ideology, is the problem. In Jane Austen and the War of Ideas Butler reads Emma as a "conservative novel" in which the heroine must learn how to discriminate "the true values from the false" and to identify and amend "what is selfish, immature, or fallible in herself" (250). Butler mentions Mrs. Weston only as she contributes to Emma's faults by overlooking them because she "lets affection cancel out her memories of Emma's failings" and by setting an "indulgent example" that contributes to Emma's prejudices (253). Furthermore, Butler examines Jane Fairfax only as Frank Churchill's secret fiancée and Emma's problematic foil. In The Historical Austen William H. Galperin also reads Emma as a bildungsroman, but he is particularly interested in the limited viewpoint of the novel that imitates Emma's failure to read accurately those around her. In this context Mrs. Weston is merely another person whom Emma misinterprets, and Jane Fairfax matters only as she interacts with Emma, Miss Bates, and Frank Churchill. The governessing issues of both characters are ignored. Claudia Johnson's chapter on Emma in Jane Austen: Women, Politics, and the Novel looks beyond the bildungsroman and argues that the novel "explore[s] positive versions of female power" (126), but Johnson focuses on the social power of a wealthy single woman (Emma) rather than on the limited household authority of a governess. She briefly mentions Mrs. Weston's marriage and her defense of the overall soundness of Emma's judgment $(125,128)$. Jane figures into Johnson's analysis only as she represents a case in which Emma was partially mistaken but also partially correct in her assessment (137-38). More recently, Eugene Goodheart's article “Emma: Jane Austen's Errant Heroine" argues that Emma does not, in fact, change at the end of the novel because her faults result from her imagination, which is a "dear" and valuable part of Emma's character and which her restrictive society disparages $(596,602)$. In this context, Mrs. Weston and Jane Fairfax are mentioned only briefly as they reveal Emma's faults. 
${ }^{4}$ According to Wrigley and Schofield's population statistics, women consistently outnumbered men in eighteenth-century England by about 100,000 (594). The ratio of women to men was so imbalanced in part because of the numerous wars during the period and the fact that many men left England to make their fortunes in the colonies, such as India and the Caribbean, often dying abroad. For example, Austen's sister Cassandra's fiancé, Tom Fowle, died of illness in the West Indies in 1797 while acting as a private chaplain to his patron and kinsman, the Earl of Craven, as he waited for the earl to grant him a second rectory, which would finally provide him with a large enough income to allow him to marry Cassandra (Nokes 139, 155, 170).

${ }^{5}$ Although I have been unable to find statistics for the percentage of mothers who died before their children reached adulthood in the period, E. A. Wrigley and R. S. Schofield estimate that $11.8 \%$ of women who were between the ages of 20 and 39 in 1811 died by 1821 (121). Mothers are often dead or absent in fiction of the period. In Camilla, Indiana's mother is dead, and during much of the action of the novel, Mrs. Tyrold is in Lisbon nursing her dying brother. In Emma, Miss Woodhouse's mother is dead, and in Austen's Pride and Prejudice, Mrs. Bennet, who is too ill-educated and often too unwell to teach her daughters appropriately, fails as a mother by not hiring a governess to ensure her daughters' education. Lady Catherine De Bourgh is horrified when Elizabeth informs her that she did not have a governess and that her education was left to her own initiative (164-65).

${ }^{6}$ Not only are Mrs. Elton's comments backhanded compliments to Jane, but they are also clear barbs aimed at Emma's failure to help Jane, even though she is far more suitably positioned than Mrs. Elton to do so. Emma clearly views her former governess as friend and social equal, yet she cannot bring herself to extend the same friendship to Jane.

${ }^{7}$ Mrs. Elton does not appear to have had a governess herself. Although the narrator gives no details of her education, her ill manners, blunders, and social grasping suggest that she did not benefit from a governess to model gentlewomanly behavior.

${ }^{8}$ Frances Burney wrote Camilla to support herself, her husband, and her son, and the novel earned enough money to build a small house known as Camilla Cottage (Doody 206). Mary Wollstonecraft explicitly abandoned governessing, which she abhorred, to earn a living as a writer, initially writing mostly translations and reviews (Tomalin 66). In doing so, she saw herself as a pioneer (she ignores Aphra Behn, Susanna Centlivre, and Eliza Haywood, all of whom had previously supported themselves with their writing, but who also suffered from questionable respectability [Todd, Secret 2-3, Pearson 205, Turner 47]), which perhaps explains why she omits writing as a professional option for women. Charlotte Lennox wrote novels and translations to support herself and her children because she was separated from her husband, who was rarely employed anyway (Todd, Sign 152). Charlotte Smith found that she needed to publish poetry and novels because of her husband's debts, which sent both of them to debtor's prison (Turner 62).

${ }^{9}$ Burney previously addressed issues of inheritance, debt, courtship, madness, and gender in her earlier novel, Cecilia (1782). As Cynthia Klekar notes, Cecilia views her inheritance as indebting her to the poor, so she determines to devote herself to charity. However, "this plan 
entangles her in an ethical dilemma of financial obligation, threatening both her fortune and identity" as well as her sanity (108). Furthermore, "Cecilia fails to recognize that her inheritance places her in debt not to the poor but to the patrilineal structures that define her social and personal identity. The money, therefore, is never hers to give" (116). Elizabeth Rose Gruner identifies similar issues in Camilla: "Burney's twin emphases on family and property suggest that identity is found by achieving one's proper inheritance" (22). Both Lionel and Clermont spend recklessly in anticipation of inheriting wealth from a maternal uncle. Their debts lead to financial and psychological hardship for their families: Sir Hugh abandons his estate at Cleves in an attempt to reduce his own expenses; Mr. Tyrold is imprisoned for Camilla's debts, which he could have paid had he not already covered Lionel's much more excessive ones; and Camilla falls into madness at an inn, believing herself solely to blame for her father's imprisonment and her family's disgrace.

${ }^{10}$ In a letter dated 1 April 1799, Burney tells her sister, "I . . a admire your purposed plan. It's [sic] success I am not afraid to say I am sure will be all you can desire" (Burney, Journals and Letters 4: 266).

${ }^{11}$ Juliet McMaster's chapter in class in The Cambridge Companion to Jane Austen briefly mentions the governess, represented by Jane Fairfax (she does not mention Mrs. Weston), as a "kind of amphibian, one who can move upwards or sink downwards in society" (126). When Tony Tanner examines "that particularly English vexed matter of class" in his chapter in Emma in his book Jane Austen, he just mentions Jane Fairfax as a "nobody" in society, and he does not address Mrs. Weston's place in Highbury society at all. James Thompson's chapter "Courtship, Marriage, and Work" spends only one paragraph examining Emma, and that paragraph mentions only the marriages of the heroine, her sister, and Harriet Smith (157). Graham Martin's article "Austen and Class" acknowledges that the "conceptual world" of Emma, although "arranged in a hierarchy which nobody challenges, . . . also allows for individual movement" (136). Yet, Martin only gives as examples of movement the upward mobility of the Coles, the Perrys, Mrs. Elton, and Mrs. Churchill, and he fails to mention Mrs. Weston's upward movment or Jane Fairfax's potentially downward, but ultimately upward, mobility. Jonathan Grossman's essay "The Labor of the Leisured in Emma: Class, Manners, and Austen" concentrates on the bad manners of Frank Churchill as the reason for Emma's ultimate rejection of him, and Grossman only briefly mentions Miss Taylor as one who demonstrates good manners and therefore is accepted into the leisure class (161). Mark Parker's article "The End of Emma: Drawing the Boundaries of Class in Austen" focuses on the heroine's relationship with Harriet Smith. David Monaghan's essay “Jane Austen and the Position of Women” brushes over Jane Fairfax as representing an anomaly in Austen's novels as the "[o]nly one of Jane Austen's major characters" who "is faced with working for a living" (110).

12 Mary Wollstonecraft also left her post as a governess to the Kingsborough family because of an alteration in her treatment by Lady Caroline Kingsborough, resulting in what Wollstonecraft felt were repeated snubs, scoldings, and embarrassments (Tomalin 52-60, Brandon 58-66).

${ }^{13}$ In contrast, Mary Wollstonecraft's Original Stories uses the specific lessons of Mrs. Mason, a fictional working governess to two motherless girls, ages 12 and 14, as the basis for an instructional narrative for children. Although Wollstonecraft shows the governess in action in 
her text, it is interesting to note that the lessons taught in Original Stories are solely moral ones, excluding the intellectual and practical skills a governess was also expected to instill in her pupils.

${ }^{14}$ If Miss Taylor were to stay in the Woodhouse home as Emma's lady companion, she would remain an employee who must work for a living, even though that work would mimic the activities of a woman of the leisure class.

${ }^{15}$ After the death of her father in 1805, Austen, her mother, and her sister lived first with her brother Frank in Southampton and then in a cottage on her brother Edward's estate at Chawton in Hampshire. 


\section{Chapter 4}

\section{A Famous Formal Quiz: Marriage Ideology, the Spinster, and Dissent}

\section{in The Wanderer, Emma, and Millenium Hall}

Of course, not all unmarried leisure-class women in the period became governesses: some unmarried women lived with family or friends, found other forms of rare genteel employment (such as a lady's companion), or more rarely, had enough inheritance to live independently. Historians point out that from 1760 to $1820,6-7 \%$ of women never married (Wrigley and Schofield 260). Yet despite forming what Bridget Hill describes as a "sizeable minority" (2), unmarried women have largely been ignored by historians. Hill notes:

The subject of spinsters has so far attracted little attention from historians. All too often in the records no real distinction is made between married and unmarried women. Or else unmarried women are inevitably regarded as the unfortunate ones who failed in their efforts to get a husband. It is more surprising that feminist historians have also chosen largely to ignore unmarried women as so much of their heritage has been shaped by them. (3)

Such scholarly absence, Hill argues, reflects the invisibility of spinsters in the eighteenth- and nineteenth-century historical record: "Spinsters of the past form a minority who are often difficult to identify. The very shame and scorn with which spinsters were regarded in the past often makes them virtually invisible. An unmarried daughter was regarded at best as an unpaid domestic servant, at worst a source of shame, since her presence indicated that the family could not afford to marry her off" (3). Amy Froide agrees, noting "how successfully singlewomen have been expunged from our historical consciousness. Contemporary records often rendered these women invisible, but historical scholarship has only perpetuated and exacerbated the 
neglect" (217). When spinsters do appear in the historical record, they are often presented as a stereotype. Froide surveys the portrayals of spinsters in a number of literary texts, including works by Daniel Defoe, Arthur Murphy, Tobias Smollett, Henry Fielding, and William Hayley, as well as anonymous satires, and she concludes that the "negative stereotypes about spinsters and old maids claimed that such women were useless, lonely, barren, and bereft individuals; and that they were either to be pitied or scorned" $(176-79,218)$.

As a basic definition, a spinster ${ }^{1}$ was an old, unmarried woman, and the stereotypes of spinsters intensify the depictions of the three categories of difference identified in this definition: marital status, age, and gender. The most definitive of these categories was the spinster's marital status. Froide argues that marital status functioned as much as a category of difference (especially for women) as gender and race in Early Modern Britain. Because women were expected to become wives and mothers, and they were educated with this goal in mind, those who did not marry were marginalized in two key ways. First, they were expected to be nonsexual beings, since female sexuality was expected to take place within the boundaries of marriage for the purpose of procreation. Katharine Kittredge notes, "Because she was viewed as having already turned irrevocably away from the socially accepted role for women (wife and mother), the spinster was inevitably regarded as outside the sexual norm for 'mature' women" (253). Such women, when not cited as examples of what young women should avoid, were often ignored in prescriptive literature. Susannah Ottaway points out, “Because women's main role in society was to bear and raise children - and it should be noted that the eighteenth century was a period in which this role was increasingly sentimentalized and centralized-women who were not actively engaged in producing or training children fell outside much of the dominant discourse concerning their gender" (41). When they were not ignored by the prevailing 
discourse, spinsters were viewed as wasted commodities because they were not fulfilling the biological, biblical, and national imperatives to reproduce. In fact, Susan Lanser argues that spinsters become the target of satire and comedy in the eighteenth century because of "an urgent perceived interest in increasing the British population, and that promotion of fertility in an England with high numbers of unmarried people was abetted by the dramatic discrediting of the female body that did not reproduce" (309). ${ }^{2}$

Second, because they did not marry, spinsters had even fewer guidelines for adult behavior than the typical woman who lacked guidance on modifying the role of wife and mother as she aged. Froide notes that "social adulthood and householder status in England were tied to marriage" (219). Socially and economically a spinster may remain dependent upon her consanguineal family like a girl, but she also was a woman. In trying to navigate this contradiction, a spinster may act younger than her biological age, since she was not the wife and mother that female education assumed the adult women would be. Or the spinster may act older than her age, though as Kittredge points out, this choice could have dangerous consequences, because "[i]f she relaxed the rigid restrictions placed on young virgins too soon, her reputation would be irrevocably damaged and she was liable to be considered a fallen woman" (253). Thus, the spinster's unmarried status subjected her to additional contradictions in gender ideology of the period.

The spinster also experienced an intensification of the cultural attitudes toward old women. Ottaway notes that while "aged, elite men, and ... many of the middling sorts," experienced old age in "an especially congenial context: a veritable golden age," "old women of the elite and middling classes were less fortunate, and inequities in law and property hindered their ability to maintain themselves into old age. Their experience of old age was also tainted by 
the eighteenth-century fixation with a youthful physical ideal for women, so many old women, even those of the intellectual elite, experienced their old age as a time of personal loss" (14). Kittredge adds, "Although there are some images in which mature women were physically (and sexually) powerful, the majority of the available depictions represent the process of aging as rendering older woman pathetic or grotesque. This is especially true of the extremely negative images of spinsters and widows proliferating during this period" (248). For spinsters, the loss associated with aging was exacerbated in two ways. First, the spinster "aged" earlier than other women; the spinster was often seen as "old" once she was no longer able to reproduce, while a mother might not be considered "old" until she no longer had children at home. In her valuable study Women Writers and Old Age in Great Britain, 1750-1850, Devoney Looser articulates this inequality, noting that in her book “old age will be understood to indicate a person's having reached the age of 60 - except in the case of 'old maids,' who might have been considered old from age 30 or 40 onward" (9). Thus, the spinster faced the risk earlier of being stereotyped as displaying the "common faults of [female] old age" as described in The Female Aegis (1798): gay amusements, affectionate tendencies, querulousness, peevishness, and garrulousness (Looser 14).

In addition to aging earlier than her married counterparts, the spinster often faced a worse economic situation than married or widowed old women. Ottaway notes that the use of employment-based pensions increased during the period, but these were generally available only to men who worked in some trades and crafts, the civil service, or the military, and their widows, while spinsters found themselves outside the margins of such aid (8-9, 75-79). Under Britain's social and economic structure, leisure-class women were economically dependent—generally on 
her father or husband — but a spinster by definition had no husband and often had lost her parents, leaving her economically vulnerable.

Despite the economic and cultural marginalization that the spinster faced, she persisted throughout the period. A number of material issues contributed to her creation, including the uneven ratio of women to men in England (see chapter 3, note 4); primogeniture, which significantly limited the inheritance of daughters, who, unlike younger sons, were expected not to work; and women, like Burney and Austen, who turned down suitors they did not love. As material conditions contributed to the creation and marginalization of the spinster, ideological ones did as well. As Froide notes, "England largely lacked a space (both conceptual and real) for singlewomen in its society. The Protestant Reformation abolished the nunnery, and did not replace it with any other institution for never-married women in the early modern period" $(180){ }^{3}$ Historians of Britain in the long eighteenth century repeatedly note the ideological importance of marriage. Olwen Hufton points out: "The literature of good advice placed marriage at the centre in the lives of women and men... The view was generally endorsed by European society and monogamous marriage was seen as the institution at the heart of the social system, a position it had occupied for so long that the memory of man ran not to the contrary" (62). Likewise, Froide notes that "the religious and social ideal in post-Reformation England was that all women would marry and have children, but this ideal diverged notably from the reality" (2). The spinster not only embodied this diversion from marriage ideology; she called attention to a key ideological faultline: although all leisure-class women were expected to marry (and increasingly, to marry for love), women also needed a sufficient dowry to marry, which primogeniture often prevented them from possessing. 
Because of the spinster's position on this faultline, it is little wonder that, as Lanser points out, "old-maid discourse so frequently exposes its own seams of illogic, its artificialityindeed its status as ideology.... Most of the discourses admit that there is nothing intrinsically negative about being single; the problem lies in social hostility, which is thus implicitly (and often explicitly) identified as the major reason to avoid singlehood" (312-13). In drawing attention to ideological contradiction, the spinster, by her very existence, created space for dissent from the ideological, even if that space is not fully utilized or fully articulated. Alan Sinfield notes that contradiction is inherent in ideological constructs, and such faultlines are "where failure — inability or refusal—-to identify one's interests with the dominant may occur, and hence where dissidence may arise" (41-42). But, he admits, "dissident opportunities are always limited—otherwise we would not be living as we do. Revolutionary change is rare and usually dependent upon a prior buildup of small breaks; often there are great personal costs" (45). Yet despite the often limited nature of the spinster's dissent, her challenge to marriage ideology merits examination.

Although "[t]he old maid was a stock figure who appeared in all genres of literature" (Looser 82), this chapter focuses particularly on the spinster's narrative and ideological functions in courtship novels of the period. She serves as a stereotype and as a challenge to the stereotype. Jean B. Kern has surveyed the portrayal of the spinster in eighteenth-century fiction and argues that while spinsters “appeared in men's novels as sex-starved, frustrated, and disagreeable stereotypes," female authors often "individualized their old maid characters beyond stereotypes" (201). Female authors challenged the spinster stereotype both by "attempt[ing] to explain the stereotype of the old maid by showing her economic dependence, her sexual frustration, or her loneliness" and by seeking a solution to her plight (209). In courtship novels the spinster 
functions most obviously as a foil to the heroine, an example of the (usually unpleasant) result of not marrying. Yet representations of the spinster in courtship narrative are more complex than being mere foils. Froide argues that the "successful erasure of women who did not marry, always making them appear to be aberrations or small in number, has allowed the supposed norm — the marital couple and nuclear family — to appear unchallenged" in the historical record (217). However, the spinster's presence in the courtship novel clearly represents space for dissent from marriage ideology.

Such dissent may arise from the author's intent or may simply be inherent within the plot or the arguments made by the words, action, and fictional placement and function of individual characters. In Frances Burney's The Wanderer; or, Female Difficulties (1814) the affluent Miss Bydel is a stereotypical spinster in terms of her behavior, yet she functions atypically—not as a foil to the heroine's courtship but to the heroine's good character. Miss Bydel's shallow and vulgar character, despite her money, contrasts with the well-bred but impoverished Juliet's strong morals. In this plot, the decay of marriage is seen not as the problem but as a symptom of the unraveling of morality, and dissidence is found not in the spinster herself but in the rejection of the vapid class pride that characterizes society and that she, in part, represents. Miss Bates, in Jane Austen's Emma (1816), exhibits some stereotypical faults of the spinster, but she also models good nature and is well accepted in her community. She functions less as a marital warning to the titular heroine and more as a measure of Emma's maturity and character. Her disappearance from the conclusion of the novel indicates not an erasure but rather an acknowledgement of this important and unexpectedly influential spinster. Finally, the spinsters in Sarah Scott's Millenium Hall (1762), something of an anti-courtship novel, demonstrate how female social duty might be fulfilled without wives and mothers. Yet these women's superior 
economic position, their maintenance of class difference, and their promotion of marriage for other women, means that the dissident space they open remains limited only to women of their class, though the social critique of their philanthropy calls into question the prevailing economic structure of English society.

"Not the Smallest Influence": The Stereotypical Spinster's Ambivalent Place Within the

\section{Community in The Wanderer: Miss Bydel}

In Burney's The Wanderer the spinster is depicted stereotypically, and her behavior and her place in the community contrast sharply with the behavior and social status of the heroine, Juliet Granville, the eponymous wanderer. Rather than serving as the typical warning to marry, Miss Bydel functions as a symptom of a decaying morality that must be saved not by the general advocacy of marriage, but by the marriages of the moral characters who are capable of rescuing the society. As a single woman with "a large and unexpected fortune" (Burney 80), Miss Bydel's position within her community is that of stereotypical spinster as summarized by Froide: “pushy, nosey, greedy, and ... prudish" (178), and she fulfills John Bennett's description of the spinster in his Letters to a Young Lady on Useful and Interesting Subjects (1789): "she wanders through a wide, bustling world, uncomfortable in herself, uninteresting to others, frequently the sport of wanton ridicule, or a proverb of reproach" (2.162).

Miss Bydel is repeatedly "pushy" and "nosey," demanding that Juliet answer her endless demands for both personal information and gossip, often claiming that she only wants to know "this one thing." She regularly interrogates the Incognita, insisting that the heroine reveal her name: "In the first place, tell me, if you please, what's your name?" (81). And again: "[O]nly be so kind as to let me know why you make such a secret of who you are? Every body asks me the question, go where I will; and it's making me look no better than a fool; to think I should be at 
such an expence as to hire a harp for a person I know nothing of" (257). Yet Miss Bydel does not want to know just "one thing." Instead she harasses Juliet ad nauseum for information about Juliet's past: "Pray, first of all, young woman, what took you over to foreign parts? I should like to know that" (80). She continues: "I don’t want to ask any of your secrets, as I say, Mrs. Elless, for I understand you don't like to tell them; but it will be discovering no great matter to let me know whether your friends are abroad or in England? and what way you were maintained before you got your passage over in Mrs. Maple's boat" (81). Still later, Miss Bydel remarks, "But pray tell me this one thing, child; what was the first motive of your going over the seas? And what might be the reasons of your coming back again in such an untowardly sort of manner? without any money, or any one to be accountable for your character?" (214). ${ }^{4}$ She boldly asks what everyone wonders about the heroine, but few, other than perhaps Mrs. Maple and Mrs. Ireton, demand the information so rudely.

When directly demanding information from the heroine fails, Miss Bydel desires Juliet's confirmation of the gossip she has heard: "And I am told, too, since it's being found out that you are a young lady of fashion, that it's the high talk that you've made a conquest of Lord Melbury; and I can't but say but I should like to know if that's a report that has got any foundation. Pray will you be so kind as to tell me" (213). In a similar vein, Miss Bydel interrogates Juliet about her relationship with Mrs. Maple: “One piece of information, however, I should be really glad if you would give me; and that is, whether you are come over to settle here, or only upon a visit to Mrs. Maple? And whether she has the care of your fortune, as a sort of guardian; or whether it is all in your own hands" (213). When Juliet reveals that she is seeking lodging outside of Mrs. Maple's home, Miss Bydel's demands for information become more pointed and even ruder: "But how comes it,- - for that can be no secret, - that you are looking out for a lodging? I should 
like to know what all that means. Pray what may be the reason that Mrs. Maple does not find you a lodging herself? And who is to take care of you? Does she lend you any of her own servants? These things, at least, can be no secrets, or else I should not ask" (216). ${ }^{5}$ Miss Bydel clearly delights in interrogation, for even when she does extract a response from Juliet, it leads only to more questions from the never-satisfied gossip. Once Juliet begins giving music lessons, Miss Bydel visits her, hoping to weasel out of her additional gossip, just as she targets all of her acquaintances for gossipy persecution: She "claimed constantly, however vainly, . . . the private history of the way of life, expences, domestics, and apparent income, of every family" Juliet enters (240). Thus, Miss Bydel fulfills the stereotype of the nosey, gossiping spinster.

Miss Bydel is also greedy, or at least stingy, despite her large fortune. Although she agrees to rent a harp for Juliet, she does so not as an act of charity and expects to be repaid (224). When she discovers that Juliet has paid her debts to tradespeople but not for the harp, she is incensed: "I should be glad to know, then, why I was to be the only person left out, just only for my complaisance in waiting so long? ... For though I have served you with such good will Mrs. Ellis, while I thought you poor, I must be a fool to be kept out of my money, when I know you have got it in plenty" (353). She combines her stinginess and her nosiness when she demands details from Miss Arbe about a piece of silk she has purchased to be made into a gown for Juliet: "Pray, Miss Arbe, what did you give a yard for it, . . . and how much will the body-lining come to? I hope you know of a cheap mantua-maker?” (314). Miss Bydel clearly expects that Miss Arbe, something of a spinster-in-training, will share her parsimony and nosiness. In this way Miss Bydel seems to accept the stereotype of the spinster not only for herself but for other women as well, and she signals that she is willing to perpetuate the stereotype by encouraging such behaviors in Miss Arbe. 
Miss Bydel further fulfills the stereotype of the spinster by displaying excessive prudishness. When Sir Jaspar Herrington invites her into his room she exhibits over-the-top primness, exacerbated by her own gossipy nature:

[T] hat lady, not aware that nothing is less delicate than professions of delicacy; which degrade a just perception, and strict practice of propriety, into a display of conscious caution, or a suspicion of evil interpretation; almost angrily answered, that she could not for the world do such a thing, for it would set every body a talking: "for, as I'm not married, Sir Jaspar, you know, and as you're a single gentleman, too, it might make Miss Matson and her young ladies think I don't know what. For, when once people's tongues are set a-going, it's soon too late to stop them. Besides, every body's always so prodigious curious to dive into other people's affairs, that one can't well be too prudent." (415-16)

Yet Miss Bydel seems oblivious to the fact that she is projecting her own personality and values onto society in her last two sentences. As a woman alone, without a husband, close friend, or apparently close family member, she lacks someone to give her social perspective. She continues to demonstrate excessive propriety when young Gooch fetches Mr. Scope from the milliner's shop: ““Well, this is droll enough!' cried Miss Bydel, palpably enchanted, though trying to look displeased; 'only I hope you have not told Mr. Scope 'twas I that sent you for him, Mr. Gooch? for, I assure you, Mr. Scope, I would not do such a thing for the world. I should think it quite improper. Besides, what will Miss Matson and the young milliners say?" (417). Miss Bydel reveals that her prudishness results not from an acute sense of propriety but, as a great gossip herself, from fear of becoming the subject of rumors. Yet despite her fear of being talked about, Miss Bydel becomes the target of ridicule on several occasions and serves as a 
negative example for young women who may consider not marrying. Elinor refers to Miss Bydel and Mr. Scope collectively as "two famous, formal quizzes," indicating that the spinster is well known for being eccentrically proper. Miss Arbe also scorns Miss Bydel, telling Juliet, "Miss Bydel, ... like all other old maids, is so precise about those sort of particulars, that, though she has not the smallest influence with any body of any consequence, as to any thing else, she is always depended upon for that sort of thing" (264). Thus, Miss Bydel represents the stereotypical spinster in fiction of the period: pushy, nosey, greedy, and prudish, and the target of other people's scorn.

Despite Miss Bydel's stock character, however, Burney's novel does not use her in a stereotypical way - to serve as a warning to the heroine to marry, or else. In fact, one of the twists of The Wanderer is that from the opening of the narrative Juliet is trapped in an illegal forced marriage, and thus does not need the warning about marriage that a spinster might provide. Instead, Miss Bydel serves to highlight the heroine's good character, and to critique the society that accepts Miss Bydel while largely ostracizing Juliet. Miss Bydel, though she received "a large fortune . . late in life," has "neither the education nor manners, that might have taught her that its most hateful privilege is that of authorizing unfeeling liberties" (213). Thus, she inflicts her prying demands on Juliet, who, though temporarily indigent, is the well-educated, sensitive, and well-mannered daughter of an earl. While Juliet accepts her loss of status with grace, Miss Bydel grasps at social standing. Miss Bydel asks Juliet at the last minute to attend a concert with her, but then she abruptly abandons the heroine upon arrival in order to join more prestigious company (242). Later when Sir Lyell Sycamore claims not to know who she is, the offended Miss Bydel exclaims, "Well, that's really odd enough! Did not you see me with Mrs. Maple at that blind harper's concert?" (262). Finding that she lacks sufficient status to be known 
to Sir Lyell, she attempts to boost her standing by emphasizing her acquaintance with Mrs. Maple. Gender and class ideologies are intertwined in the period, and society's acceptance of the wealthy but vulgar Miss Bydel and their rejection of the cultured but poor Juliet call into question these ideologies. If women are valued only for their money and their fathers, then any value that derives from good character is meaningless. If class status can be bought through "sordid" wealth (213), then birth and education become worthless. ${ }^{6}$

Following courtship narrative convention, The Wanderer concludes not only with the marriage of Juliet (freed from her illegal marriage by the commissary's fortuitous death) and Harleigh, but with a multitude of marriages: Lord Melbury marries Lady Barbara Frankland; Sir Jaspar "rescue[s] the simple Flora from impending destruction, by portioning her in marriage with an honest vigilant farmer"; and Juliet's "faithful” servant Ambroise weds Dame Fairfield after her first husband is hung for his crimes (871). Yet these concluding marriages are anomalous, for the body of the novel is oddly bereft of married characters, as Janice Farrar Thaddeus points out:

In The Wanderer marriage seems to be a completely exhausted institution. Among Burney's middle-class characters what is most remarkable is how few are married. Her three furies-Mrs Howel, Mrs Maple, and Mrs Ireton—are either unmarried or widowed. Indeed, none of her upper-class women seems to be attached to a living husband, and the older men who act as facilitators and occasional chorus in the novel are bachelors: Admiral Powel, Sir Giles Arbe, Mr Riley, and Sir Jaspar Herrington. (169)

Betty Rizzo comments on The Wanderer: "Most of the characters are single, but Gabriela, who is married and who merits happiness, is solitary and unappreciated. . . . [W]omen's loneness is 
emphasized by Burney's giving only negative examples of marriage: it is not an actual resource" (108). Although The Wanderer calls into question gender and class ideologies, it at least partially upholds the institution of marriage — but rather than filling the novel with married persons, Burney reserves marriage as a reward for the virtuous characters. Those worthy of marriage are not those with the money to marry, but those whose behavior and morals have proven them capable of revitalizing the decaying society. Thus, the working class Flora, Ambroise, and Dame Fairfield all find happiness in marriage, while the wealthy but vapid Selina, Ireton, and Miss Bydel remain single at the novel's conclusion. Burney's final novel argues not that all women should marry, for the shallowness of one generation (the three furies) is clearly reproduced in the next (Elinor, Selina, and Ireton). Yet marriage is still vital to the social fabric, as long as marriage breeds a new generation that will reinstate the morality displayed by Juliet, Harleigh, and their closest friends.

\section{“A Most Uncommon Degree of Popularity": The Popular Spinster's Secure Place Within the Community in Emma: Miss Bates}

Like The Wanderer, Austen's Emma uses a spinster character, Miss Bates, to serve as a foil to the heroine. But while Juliet's character is enhanced in comparison to Miss Bydel's, Miss Bates serves as a much needed warning and object lesson to Emma, who lacks Juliet's maturity and kindness. Her importance in the community and to Emma's courtship narrative draws attention to the ideological faultline the spinster represents and calls into question marriage ideology. Like Miss Bydel, Miss Bates is “a great talker” (Austen 21). In fact, Isobel Grundy asserts, "Talking too much is virtually her defining characteristic" (45). Yet, while Miss Bydel uses speech to pry into the lives of others, Miss Bates is merely "full of trivial communications and harmless gossip" (Austen 21). In addition, although Emma typically pays little attention to 
Miss Bates' prattle, the spinster's comments of reveal astute observation of the world around her (unlike the self-absorbed Miss Bydel). Furthermore, although she displays the stereotypical spinster fault of loquacity, Miss Bates is in many ways Miss Bydel's opposite:

[She] enjoyed a most uncommon degree of popularity for a woman neither young, handsome, rich, nor married. ... [S]he was a happy woman, and a woman whom no one named without good-will. It was her own universal good-will and contented temper which worked such wonders. She loved every body, was interested in every body's happiness, quick-sighted to every body's merits; . . . The simplicity and cheerfulness of her nature, her contented and grateful spirit, were a recommendation to every body and a mine of felicity to herself. (21) While the bitter Miss Bydel spreads gossip and unhappiness, Miss Bates spreads cheer and goodwill. Miss Bates's socio-economic situation is typical for a spinster- the impoverished, unmarried daughter of a deceased clergyman, who cares for her aging mother-but despite the difficulty of her life, she does not fulfill the stereotype of the spinster as the wealthier Miss Bydel does.

Yet in spite Miss Bates's good qualities, Emma recoils when Harriet suggests that if the heroine does not marry she will "be an old maid at last, like Miss Bates" (84). Emma responds, "That is as formidable an image as you could present, Harriet; and if I thought I should ever be like Miss Bates ... I would marry to-morrow. But ... I am convinced there can never be any likeness, except in being unmarried .... I shall not be a poor old maid; and it is poverty only which makes celibacy contemptible to a generous public" (84-85). Thomas Gisbourne, though he pities spinsters, admits "that certain peculiarities of deportment, certain faults of disposition, are proverbially frequent in women, who have long remained single," but he blames their 
"situation of life" for "encourag[ing] some particular errors and failings," since spinsters "are persons cut off from a state of life usually regarded as the most desirable" (9-10). Emma recognizes the stereotype of the old maid character, likewise attributing its development to poverty: "[A] very narrow income has a tendency to contract the mind, and sour the temper. Those who can barely live, and who live perforce in a very small, and generally very inferior, society, may well be illiberal and cross" (85). Yet Emma admits that she does not dislike Miss Bates because she acts like a stereotypical old maid; Emma objects to Miss Bates even though she does not fulfill the stereotype: "This does not apply, however, to Miss Bates; she is only too good natured and too silly to suit me. .. Poverty certainly has not contracted her mind: I really believe, if she had only a shilling in the world, she would be very likely to give away sixpence of it; and nobody is afraid of her: that is a great charm" (85). Thus, Emma admits that rather than being stingy and irritable, like the stereotypical old maid, Miss Bates is actually generous and pleasant. Emma recognizes the limitations of the stereotype when applied to a specific spinster, yet her acknowledgement that Miss Bates does not completely fulfill the stereotype does not prevent her from treating Miss Bates snobbishly. In contrast to Emma’s self-importance, Miss Bates is kind to everyone. The spinster in Austen's novel serves less as a warning to the heroine of the perils of remaining unmarried, than as an important object lesson to the heroine, whose maturity and character are measured by her treatment of Miss Bates.

In recognizing the spinster stereotype, Emma calls attention to its ideological foundation. Emma warns Harriet that "[a] single woman, with a very narrow income, must be a ridiculous, disagreeable, old maid! the proper sport of boys and girls; but a single woman, of good fortune, is always respectable, and may be as sensible and pleasant as anybody else" (85). Emma's claim reflects, contrasts, and comments on the opening sentence of Austen's Pride and Prejudice: "It is 
a truth universally acknowledged, that a single man in possession of a good fortune, must be in want of a wife" (3). While the narrator of Pride and Prejudice ironically recognizes the cultural and ideological demand that "a single man . . . of . . . good fortune" marry, Emma selfconsciously attempts to deny the same impetus for herself, "a single woman, of good fortune." In doing so, she alludes to several cultural phenomena in late eighteenth- and early nineteenthcentury England. Emma correctly recognizes that wealthy women lack the same financial incentive to marry that women without financial independence encounter, but she resists the patriarchal requirement that all women must marry by utterly ignoring the ideology. While Mrs. Bennet claims Mr. Bingley and his "four or five thousand a year" for one of her daughters even before he has moved into the neighborhood (4), Emma insists that instead of increasing her likelihood of marriage, her fortune of thirty thousand pounds guarantees her independence, such as that enjoyed by Miss Bydel, who despite her wealth, fulfills the spinster stereotype. She points out to Harriet the desirability of her current situation: "Fortune I do not want; employment I do not want; consequence I do not want: I believe few married women are half as much mistress of their husband's house, as I am of Hartfield; and never, never could I expect to be so truly beloved and important; so always first and always right in any man's eyes as I am in my father's" (84). Only falling in love, Emma asserts, could cause her to change her mind: "Were I to fall in love, indeed, it would a different thing! but I have never been in love; it is not my way, or my nature; and I do not think I ever shall. And, without love, I am sure I should be a fool to change such a situation as mine" (84). Here Emma ideological demands by renouncing desire.

Thus Emma points out the tension between the patriarchal ideology that demands that all women marry and the romantic ideology of marriage for love: wealthy Emma may choose not to marry without love while a woman with no financial independence, such as Charlotte Lucas in 
Pride and Prejudice, finds the financial impetus for marriage so overpowering that she may marry an irksome man like Mr. Collins. At age 27, Charlotte is verging on spinsterhood, and marriage provides the only means available to her of leaving her parents' home: "Without thinking highly of men or of matrimony, marriage had always been her object; it was the only honorable provision for well-educated young women of small fortune, and however uncertain of giving happiness, must be their pleasantest preservative from want” (122-23). As Charlotte explains to Elizabeth Bennet, "I am not romantic you know. I never was. I ask only a comfortable home; and considering Mr. Collins's character, connections, and situation in life, I am convinced that my chance of happiness with him is as fair, as most people can boast on entering the marriage state" (125). Thus young, wealthy women have the financial stability to marry only if they fall in love, while older, poorer women may find themselves pressured into marrying a Mr. Collins.

Emma's behavior toward Miss Bates initially reveals deep-seated snobbery. She dreads visiting Mrs. and Miss Bates, even though she knows it is her duty to visit them: "She had had many a hint from Mr. Knightley and some from her own heart, as to her deficiency — but none were equal to counteract the persuasion of its being very disagreeable, - a waste of timetiresome women - and all the horror of being in danger of falling in with the second rate and third rate of Highbury, who were calling on them for ever, and therefore she seldom went near them" (155). Emma's dislike of visiting the Bateses is, as Beth Fowkes Tobin points out, “forgivable" (62), but at Box Hill she moves from snobbery to utter rudeness when Miss Bates's loquacity threatens to steal the attention Emma has thus far monopolized during the picnic. In fact, as Ronald Hall points out, Emma's insult "is implicitly and ironically self-reflexive: it is Emma, not Miss Bates, who talks too impulsively and unthinkingly without true attentive 
listening to others"; for although Miss Bates is talkative, her speech displays "warmth and observation of the world around her," while Emma is frequently self-centered and "repeatedly fails to listen properly and therefore misapplies and 'misreads' the very words she hears" (146). Once again Emma is aligned with Miss Bates, despite her insistence that they are nothing alike. Yet their similarities make Emma's treatment of Miss Bates all the more an important index of the heroine's character and maturity.

At Box Hill Miss Bates is clearly hurt by Emma's attempt at wit, telling Mr. Knightley, "I must make myself very disagreeable, or she would not have said such a thing to an old friend" (371). Knightley scolds Emma's bad behavior: "How could you be so unfeeling to Miss Bates? How could you be so insolent in your wit to a woman of her character, age, and situation?Emma, I had not thought it possible" (374). When Emma attempts to defend herself by claiming that her comment "was not so very bad," Knightley responds, "I wish you could have heard her honouring your forbearance, in being able to pay her such attentions, as she was for ever receiving from yourself and your father, when her society must be so irksome" (374-75). Knightley further points out that Miss Bates's status as a poor spinster means that she should be treated with more kindness than those of a higher rank:

Were she a woman of fortune, I would leave every harmless absurdity to take its chance, I would not quarrel with you for any liberties of manner. Were she your equal in situation — but, Emma, consider how far this is from being the case. She is poor; she has sunk from the comforts she was born to; and, if she live to old age, must probably sink more. Her situation should secure your compassion. It was badly done, indeed! (375) 
Knightley's lecture hits its mark and serves as a turning point for the heroine, who admits the legitimacy of his criticism during the carriage ride home: "She was most forcibly struck. The truth of his representation there was no denying. She felt it at her heart. How could she have been so brutal, so cruel to Miss Bates!" (376). Yet even Knightley recognizes the absurdity in Miss Bates' loquacity, but he agrees with Emma's earlier analysis of spinsterhood that a spinster's economic situation makes her a target of criticism even as it should stimulate compassion. Emma demonstrates her repentance by visiting the Bateses the following morning with a new attitude: “'The ladies were all at home.' She had never rejoiced at the sound before, nor ever before entered the passage, nor walked up the stairs, with any wish of giving pleasure, but in conferring obligation, or of deriving it, except in subsequent ridicule" (378). Emma's reformation is key to her deserving her eventual union with Knightley, as she learns not only to treat others with respect but also to listen. As Hall notes, "This is aptly and movingly shown in her climactic encounter with Mr. Knightley" (146). Thus, Emma's interactions with Miss Bates help her to mature into the woman who both recognizes her love for Knightley and deserves his love for her.

Although she plays an important part in preparing Emma for marriage, as a spinster Miss Bates draws attention to the ideological faultline, demonstrating not merely the impossibility of marriage for all women of her class but also illustrating that success on the marriage market depends on both a good character and a good dowry, and thus she threatens to undermine the cohesiveness of the novel's conventional conclusion. The novel's structure limits but does not eliminate this dissent. Looser notes that "though Miss Bates is a good-natured fixture in the Highbury world, she entirely drops out of the final two chapters. She is in no way central to the portion of the narrative in which Emma and Mr. Knightley's happy marriage is concluded. In 
short, even if we see Emma as redeemed insofar as her poor treatment of old maids is concerned, Austen leaves Miss Bates hanging out to dry at the novel's end" (92-93). Yet although none of the other characters in the novel acknowledge the importance of Miss Bates in preparing Emma for marriage, it is precisely because of her influence both in the community and on Emma as well as the power of the ideological dissent inherent in her role, that Miss Bates is silenced. As Sinfield notes in commenting on Shakespeare's plays, "The female characters . . f fall silent at the moments when their speech could only undermine the play's attempt at ideological coherence" (73). Furthermore, Grundy points out: "Yet in a sense this silencing is only temporary. Miss Bates has to be quieted so that the happy ending can take place. ... But Miss Bates cannot be truly silenced. ... [H]er earlier monologues remain in the novel, available for rereading; and she is never reproved (as Emma is) for talking too much or inappropriately" (55). Ultimately, the silencing of Miss Bates at the novel's end only emphasizes the dissent she represents and the instability of the marriage ideology promoted by the happy conclusion of courtship narrative.

\section{"That Amiable Family": Spinsters Create Their Own Community in Millenium Hall: The Ladies}

Sarah Scott's 1762 novel Millenium Hall contains the narratives of the five single women (four spinsters and one widow) who, along with Mrs. Maynard, inhabit the titular estate. For these women, patriarchal society has been detrimental to their wellbeing and the material conditions of their lives. As a result, they choose to expand the definition of female duty beyond the roles of wife and mother, and in doing so, they create a space for themselves on the margins of their culture. By finding alternative ways of fulfilling female social duty beyond bearing and rearing children, they provide examples of the social value of spinsters. The novel suggests that 
marriage ideology unnecessarily constricts women's choices, since women can still fulfill female social imperatives without being wives and mothers. In this way, Millenium Hall can be seen as an anti-courtship novel. As Linda Dunne notes, "The formation of . . mutually supportive relationships between women is the primary plot of Millenium Hall, just as surely as the search for a suitable husband is the generic plot of the canonized novels of the eighteenth and nineteenth centuries" (61). Despite the plot's opposition to traditional courtship narrative, however, the novel is not revolutionary in its approach to gender roles. The ladies' ability to alter the method by which they fulfill gender ideology depends upon their class status as women of independent means, and thus they maintain a certain degree of patriarchy by upholding class difference. Furthermore, although the women opt out of marriage for themselves, they do not encourage such a choice for others.

The inhabitants of Millenium Hall implicitly advocate a preference for spinsterhood and sorority, and their narratives reveal at least two problems with marriage and patriarchy for women. The most obvious difficulty that the women encounter is predatory men, for patriarchal ideology allows, and even sanctions, men to mistreat women in a number of ways. ${ }^{7}$ Miss Mancel is nearly seduced by her libertine guardian, Mr. Hintman, and only his providential death saves her (97-102). Mr. Morgan insists on marrying Miss Melvyn, even though he knows she does not love him. The marriage is profoundly unhappy; Mr. Morgan's personality is described as "a mixture of passion and peevishness," and he treats his wife both with "ill-humour" and "nauseous fondness" (134-35). While still a teenager, Lady Mary Jones twice is nearly seduced, first by Mr. Lenman, who already has a wife, and then by Lord Robert St. George, an aristocratic libertine (174-78, 180-84). ${ }^{8}$ Lee Cullen Khanna notes that “Mrs. Maynard's inset tales foreground young women in danger, particularly young women of gentle birth who have no 
money. In these histories, there are no heterosexual relationships without cost to women" (25). In these narratives men repeatedly threaten women's physical, psychological, and sexual wellbeing.

Yet James Cruise points out that not only do these "women suffer at the hands of men, who are apt to be dissimulating, malicious, unprincipled, and whimsical," but "the various malignancies that afflict men also afflict women, particularly those who function as surrogate mother figures" (561). He then analyzes how the second Lady Melvyn, Lady Sheerness, Lady Lambton, and Lady Brumpton all fail as female mentors or guardians. What he overlooks, however, is the commitment these women display to patriarchal economic values; thus, their failure is symptomatic of the faults of patriarchy rather than suggesting a failure inherent in female mentorship. The novel therefore suggests that it is not simply men who are harmful to women but instead it is patriarchy — and anyone who upholds it, male or female — that hurts women, in part because women often find themselves caught in the ideological contradiction that they must marry and must have money to do so. Because the institution of marriage is a significant marker of patriarchy, a decision not to marry can be interpreted as a rejection of patriarchal ideology.

The narratives also demonstrate the capricious nature of wealth and inheritance, thanks in part to the English custom of primogeniture, and the effects on single women. Miss Mancel is left penniless after Mr. Hintman's death because he has left no will, but she is later implausibly reunited with her mother and becomes the heir of $£ 40,000$ (154-56). Lady Mary is "left entirely destitute of provision" when she is orphaned at age 10 because her father has "mortgaged to its full value all of his estate," which is then inherited by his eldest son (172). Lady Mary is taken in by her wealthy aunt, Lady Sheerness, but when that lady dies, Lady Mary is again penniless- 
until she receives an inheritance of $£ 10,000$ from her half-brother's widow, Lady Brumpton $(188,194){ }^{9}$ Male guardians abandon young women, leaving them with no or small means of financial support, but these women have been unusually fortunate enough to receive support (with money to spare) from female relatives. Such inheritance promotes the sororial ideology of the novel and provides for the initial financing of Millenium Hall. Thus, they find themselves financially more similar to Miss Bydel than to Miss Bates, but instead of fulfilling the stereotype of the spinster, they redefine the role.

After such problematic experiences with men, inheritance, and patriarchy, the inhabitants of Millenium Hall unsurprisingly choose not to marry (or in the case of Mrs. Morgan, to remarry), even if they eventually gain the requisite wealth. As an alternative to the culture of marriage, they live together as an "amiable family" (53). In rejecting matrimony for themselves, they preclude themselves from fulfilling female duty through the roles of wife and mother. Instead, they use their excess income to aid the community in ways that imitate (but do not perfectly replicate) traditional female duty. ${ }^{10}$ Miss Mancel summarizes their work, saying: "Our faculties and our time should be employed in directing our donations in a manner the most condusive to the benefit of mankind, the most for the encouragement of virtue, and the suppression of vice; to assist in this work is the business of speech, of reason, and of time. These ought to be employed in seeking out opportunities of doing good, and in contriving means for regulating it to the best purpose" (245). By demonstrating that unmarried women may still execute female duty, the ladies of Millenium Hall defy the stereotypes of the spinster and call into question the ideological emphasis on marriage for all women.

The ladies accomplish this challenge to marriage ideology by fulfilling the conduct manual injunctions that women educate the young, modeling and encouraging in others the 
virtues of charity, diligence, and good behavior. Instead of rearing their own children with these virtues, the ladies of Millenium Hall serve as guardians and protectors to penniless orphans (160), "every child after the fifth of every poor person" in the neighborhood (66), physically disabled persons (73), and spinsters of gentle birth but little or no fortune (115). ${ }^{11}$ The ladies also educate the young people in their care by maintaining both a girls' and a boys' school and by taking some young ladies into their home to be educated directly by them. They also promote good morals among all the people in the neighborhood by developing and enforcing codes of behavior and mediating quarrels. For the ladies, morality and a decent standard of living for all are directly linked to diligence. The ladies themselves model industry through their philanthropic activities. In this they fulfill part of Fordyce's further description of the virtuous wife, to whom "idleness is ... hateful," and who "bestirs herself with the utmost activity" $(1.213,215)$. When the visiting narrator believes he is rising early one morning, he is surprised to find that "the ladies and their little pupils were earlier risers than myself, for they were all at their various employments" (64). The ladies do not merely keep themselves and their household engaged, however; they also promote the diligence of the community. An old woman informs the narrator that she "was almost starved" because "we had not things to work with, nor any body to set us to work," until the ladies employed them spinning, knitting, and making broths and candles (65). The old woman says of the ladies: "if we are not idle that is all they desire" $(67){ }^{12}$

The ladies also model good behavior through their manners, intellect, and speech. Fordyce asserts that the virtuous wife "loves not to talk on foolish and frivolous subjects, but on such as are serious and useful; on which, when she can introduce them with propriety, she is sure to deliver herself pertinently, and gracefully. Her language on all occasions is soft and pleasing, 
expressive of a gentle mind, and a tender heart" (1.220). Likewise, the propriety of the ladies' conversation is one of qualities that impresses the narrator on his first day at Millenium Hall. He notes: "The conversation after supper was particularly animated, and left us still more charmed with the society into which chance had introduced us; the sprightliness of their wit, the justness of their reflexions, the dignity which accompanied their vivacity, plainly evinced with how much greater strength the mind can exert itself in a regular and rational way of life, than in a course of dissipation" (64). The ladies' rational yet witty conversation further demonstrates the value of a life devoted to philanthropy rather than dissipated pleasure. Thus, the ladies ultimately do not stray far from feminine ideals. They uphold gender ideology while they dissent from marriage ideology.

While the ladies' unmarried status and philanthropic work grant them a degree of authority in their own lives and in the community, and they exemplify alternative productive female roles, Scott's novel does not, in the end, suggest a radical restructuring of society. Their authority derives not merely from the fact that the ladies have the freedom to allocate their money as they see fit, but they also benefit from the good fortune of having received inheritances despite the capriciousness of the patriarchal heritage system. As the ladies seem to recognize, instead of living at Millenium Hall, they could just as easily be one of the gentlewomen who suffers "from scantiness of fortune, and pride of family" whom the ladies have established in another large house in the neighborhood (115).

When Ellison revisits Millenium Hall in the 1766 sequel, The History of Sir George Ellison, he calls on the spinsters whom "those ladies had removed from a state of mortifying dependence" to one of easy dependence. Three of these spinsters-Miss Alton and two unnamed spinsters - tell Ellison their stories, which further illustrate the problem with patriarchy 
as it is implemented for women who, unlike the ladies of Millenium Hall, never attain economic independence. These three narratives, though they vary in their details, demonstrate three general principles about the plight of the leisure-class spinster in mid-eighteenth-century England. First, the spinster often finds herself penniless upon the death of her parents, frequently because her father has failed to ensure an adequate inheritance for her. Miss Alton finds 'at my father's decease ... that his whole estate was entailed on my brother; it had not been in his power to charge it with any fortune for me, and ... I was left entirely on my brother's generosity" (Scott, History 102). ${ }^{13}$ Second, the narratives demonstrate that such loss of income affects the spinster dramatically both materially and psychologically. Miss Alton, in attempting to make herself useful to her sister-in-law, becomes overworked, taking on the roles of housekeeper, governess, and cook, until "[m]y abode at my brother's now became very irksome" (107). As the third spinster explains, "How various are the uneasinesses . . . that arise from poverty! . . [I]n those who unfortunately have been educated in a superior manner, and in their youth placed in a rank which they have not afterwards the power of supporting, the mind is the seat of greatest sufferance" (114-15). Finally, because of class expectations, the spinster is unable to earn her living through labor, which makes her dependent upon other people, a circumstance that these narrators lament. The third narrator "was determined to receive my support only from my own hands" and decides to go into service, but her relatives believe such work to be beneath her class status and refuse to give her the necessary references (115). ${ }^{14}$

Eventually all three women leave their unfortunate situations to join the society of spinsters. Yet, although these gentlewomen have escaped the dependent state that leaves them in “the severest servitude," they still retain a degree of financial dependence on the ladies at Millenium Hall, rather than becoming truly autonomous, though this is not regarded as a 
humiliating dependence because they are treated well (Scott, Description 115). Furthermore, these gentlewomen remain psychologically dependent, as the ladies have created and enforce a set of eleven rules that the gentlewomen of the society must follow (116-17). Thus, not all women in the novel experience the independence and authority enjoyed by the ladies.

Ultimately, Millenium Hall reveals deep-seated problems for women in patriarchy, but instead of suggesting a means of fully revolutionizing society and removing the stigma of female labor, Scott's novel instead argues that women need to look out for each other because it is more beneficial for a woman to rely on other women than to be dependent on men.

While the women of Millenium Hall create a space for themselves as unmarried, independent women who find alternative ways for fulfilling female social duties, the novel does not imagine a revolutionary new place for all women. Instead, the women largely uphold the social order in two ways: by maintaining class difference and by encouraging and providing the means for other women to marry. ${ }^{15}$ Some critics read the economics of Millenium Hall as progressive. For example, Linda Dunne argues:

In a very concrete way, the ladies of Millenium Hall have taken themselves and their money out of the dominant male-controlled economic system that, we are shown throughout the novel, destroys and exploits both women and nature. They have done this by not marrying and by replacing the primary economic system that is built on the wealth of patriarchal families with an alternative economy that is based on communal feminist principles. This new economy appropriates financial resources not to build or maintain private family fortunes but to nurture and protect the poor and unfortunate, the creatures of the natural world, and, most importantly, other women. (58) 
However, Dunne's reading requires overlooking both the patriarchal origin of the ladies' wealth as well their maintenance of class difference - the ladies remain wealthier benefactors who aid the poorer recipients of their charity. Thus, James Cruise notes that "these women cannot afford 'to ignore their economic origins' or their ideal country house, since for them to do otherwise would imperil not just their own proprietary ideal but also the enterprise that revolves around that domestic axis" (556). In other words, the ladies of Millenium Hall are able to live independently of men and perform philanthropic works because they are economically independent.

Similarly, Julie McGonegal argues that the ladies' socioeconomic status undermines the revolutionary aspect of their enterprise: "The delegation of gentry women to the role of social custodians empowers them politically and socially, and materially rewards them for the labour, as well as extricates them, at least partially, from networks of female commodification and exchange. But this role applied to women also obscures the exploitative side of capitalism and buttresses hierarchies between women" (301). She further argues that ladies' philanthropic work tends to reinforce patriarchy: "In a strange reversal of gender roles, the women perform the part of the paternal figure in the marriage transaction, both by equipping the poor marriageable women of their neighbourhood with dowries and by carefully instructing them in the codes of female conduct" (301). Susan Lanser also finds Scott's novel more conservative than progressive: “Millenium Hall's most apparently radical gesture is also potentially its most conservative: in clustering unmarried women in a separate, isolated space where they perform the work of reproducing patriarchy, the novel doubly defuses the threat that female affiliation could have posed" (303). Although Betty Rizzo generally reads Scott as a reformer, she admits that Millenium Hall and George Ellison are far from revolutionary: "Altruistic masters in a world 
that remains hierarchical are the only solution Scott dares to proclaim. The distinction between the male and the female spheres is marked in these two utopian novels" (317). Thus, although Scott's novels open space for dissent from marriage ideology, they simultaneously limit that dissent by asserting that only a few women are positioned to inhabit that space. Instead of treating all women as equals, the ladies of Millenium Hall maintain their superior class status over those they aid by regulating their behavior, giving them "class-appropriate" work, and educating the girls to remain within their class: the working-class girls learn household tasks while the middle-class girls learn the ornamental skills expected on the marriage market.

In fact, like the mothers of the period who were expected to promote the marriage of their children, the ladies of Millenium Hall, though rejecting matrimony for themselves, encourage the marriages of the young women whom they have educated. In defending their seemingly hypocritical support of marriage, Mrs. Morgan echoes Fordyce, saying, "We consider matrimony as absolutely necessary to the good of society; it is a general duty," which these ladies fulfill by encouraging other people to marry instead of themselves (163). They promote these marriages by providing the young women with dowries and giving gifts to "those who behave well" after they are married. The ladies also "watch with so careful an eye over the conduct of these young people, as proves of much greater service to them than the money they bestow." Overall, "[t]his encouragement has great influence, and makes them vye with each other in endeavours to excel in sobriety, cleanliness, meekness and industry" (167-68). Thus, the ladies act as parents to these young people by encouraging them to marry, providing them with the means to do so, and guiding and correcting their conduct both before and after marriage. By acting as both mother and father to the young people (educating and financing them), the ladies have considerably 
more power and authority than they would possess as traditional mothers. Thus, rather than circumventing the social order, they have repositioned themselves within it.

In the sequel, Ellison likewise reinforces marriage ideology, not only by marrying twice himself, but also by encouraging others to marry: "Sir George considered marriage as a state commanded by God, and very useful to the community; he respected it therefore both on religious and political motives; always endeavoured to promote it with propriety, and heard with pleasure that any of his friends had entered into it with virtuous and rational views" (Scott, History 202). This second novel, though purporting to be a biography of a benevolent patriarch who aids rather than harms women, ends like a traditional comedy_-with a rush of marriages: Ellison's eldest son marries Miss Blanchard, his eldest daughter marries the marquis, and one of his stepdaughters marries the eldest Mr. Blackburn (218-20). Such promotion of marriage in these novels indicates that the ladies have not created a radical new society that can be replicated beyond Millenium Hall. Just as they uphold class difference, they, and those whom they influence, also maintain the social value of marriage, as demonstrated by the promotion of classappropriate marriages. Thus, while they have revealed the deep-seated problems for women within patriarchy and created a space of social importance for themselves outside of marriage, they do not widen that space to include all women.

\section{Conclusion}

Sinfield notes that "contradictions in the ideology of marriage produced . . . an opportunity for dissidence" (45). The spinster represents one faultline at which such dissent is generated. Together, the spinsters of Burney's, Austen's, and Scott's novels demonstrate that the spinster is more than a stock character who serves as a foil to the marriageable heroine of the courtship novel. In a variety of ways, spinsters call into question an ideology that not only 
demands that all women marry when such a mandate is not always possible to fulfill. In these novels the spinster both fulfills and challenges the stereotypes of the old maid, and she parallels the conventional marrying woman in ways that draw attention to both their similarities and their differences. In The Wanderer the spinster serves as a fiendish double to the heroine and a target of criticism of accepted class ideology. In Emma she offers a largely positive example who functions as an index of the heroine's growth. The spinsters in Millenium Hall model alternative (though not fully replicable) ways of fulfilling female duty without marriage. Ultimately, the spinster creates a potentially expanded space not only for the spinster but for all women, and even the conventional marriages that the novels promote cannot fully close the space for dissent that the spinster represents.

\footnotetext{
${ }^{1}$ Historians of the spinster disagree on the best term to call her. Although the phrases "unmarried woman" and "never-married woman" become unwieldy for extensive usage, simpler terminology seems to be more controversial. While all historians I have encountered reject "old maid" as pejorative, Hill historicizes and then uses the term "spinster" as a term that was not originally intended negatively and only acquired a derogatory connotation as cultural constructions of unmarried women became more unflattering (4-5). Froide, on the other hand, rejects "spinster" and argues for the term "singlewoman" (8-9), a term that I find nearly as awkward as "unmarried woman" or "never-married woman." In this chapter I will follow Hill's example and largely use "spinster" as it is a term that was commonly used in the period (I have not found "singlewoman" used in the latter part of the long eighteenth century) but is far less pejorative than "old maid."

${ }^{2}$ Linda Colley notes that although "[i]n the last third of the eighteenth century, population growth throughout Britain and Ireland accelerated," many in the period "believed (. . . before the introduction of a census in 1800) that Britain's population was in decline." This belief led to a "cult of prolific maternity" to reverse this decline, to "compete in terms of cannon-fodder with France," and to spread the British empire around the globe $(158,240)$.

${ }^{3}$ There was ongoing recognition of this lack of space throughout the eighteenth century. At the end of the seventeenth century, Mary Astell's A Serious Proposal to the Ladies $(1694,1697)$ tried to create such a space by suggesting women's colleges, but her institutions were never implemented because they seemed too much like Protestant nunneries.

${ }^{4}$ Cf. Miss Bydel's other inquisitive comments: "So I hear, Miss Ellis, you have met with misfortunes? .. . I want to know how it all first began. Pray, my dear, in what manner did you
} 
set out in life? A great deal of one's pity depends upon what people are used to?" (221). "I should like to know how it was you got this musical turn, Miss Ellis? Were your own friends rich enough, my dear, before their bankruptcy, to give you such an education themselves? Or did it all come, as one may say, from a sort of knack?" (222).

${ }^{5}$ Cf. Miss Bydel's remark: "I hope at least I may ask, whether your friends are coming to you in your lodging? - and what you intend to do there? - and how long you think to live there? - and what is the true cause of your going there?-For there must certainly be some reason" (216). Also her comment: "Have you got your fortune with you? - or does Mrs. Maple keep it in her own hands? - or have not you got any left?-or perhaps you've had none from the beginning?" (217).

${ }^{6}$ Miss Bydel herself experiences conflict between her class consciousness and her greed. Although Miss Bydel harasses Juliet for repayment, she believes that the families of the heroine's students should not be pressured into paying what they owe her for their music lessons. She exclaims to Mr. Giles Arbe, "Goodness, Mr. Giles! . . . why what are you thinking of? Why you are calling all the ladies to account for not paying this young music-mistress, just as if she were a butcher, or a baker; or some useful tradesman." Giles asserts, "Well, so she is, Ma'am! so she is, Mrs. Bydel! For if she does not feed your stomachs, she feeds your fancies; which are all no better than starved when you are left to yourselves." Miss Bydel counters, "[M]uch as it's my interest that the young woman should have her money, for getting me back my own, I can't pretend to say I think she should be put upon the same footing with eating and drinking. We can all live when enough without music, and painting, and those things, I hope; but I don't know how we are to live without bread and meat." Although Giles replies, "Nor she, neither, Mrs. Bydel! and that's the very reason that she wants to be paid," his "attempt . . . produced no effect" (323, 326). Perhaps because the guinea and a half that she has loaned to Juliet is such a small amount, Miss Bydel's class consciousness trumps her greed, and she fails to see why Juliet should be paid.

${ }^{7}$ Fordyce in his Sermons to Young Women admits that marriage "subjects women to a great variety of solicitude and pain" even as he insists that "matrimony is necessary to the support, order, and comfort of society" (1.166).

${ }^{8}$ In addition, Miss Trentham's cousin, whom her grandmother intends her to marry, falls in violently love with her only after his marriage to Miss Melman becomes irreparably unhappy $(233,237-39)$.

${ }^{9} \mathrm{Cf}$. Miss Selvyn, who is raised by a retired tradesman of good character but small fortune. However, she eventually inherits $£ 12,000$ from her biological mother, Lady Emilia (218).

${ }^{10}$ Elliott has also explored the ladies's redefinition of domestic duty as philanthropy: "The ladies of Millenium Hall are not wives or mothers; instead of graciously presiding over a home and family, they establish and manage a philanthropic community; instead of channeling their desires toward husbands and children, they live in harmony with other women" (542). She also notes that in making this alteration, they draw attention to the problems of domestic ideology: 
Thus the outcome of Scott's use of philanthropy to enlarge upon the possibilities allowed to women by domesticity was, paradoxically, an exposure of the paradoxes of domesticity. According to the domestic ideal, love defined a woman, but it also annihilated her. Marriage was the safe and proper place for a woman, but once married she legally ceased to exist. Sentimental stories taught women how to practice virtue, but they could also seduce. Women were the moral saviors of society, but only if they allowed themselves to be reduced to an image of sexuality. (548)

${ }^{11}$ In doing so, they promote to their primary duty what Fordyce's Sermons prescribes as a supplemental responsibility for wives when he expounds on the description of the virtuous wife in Proverbs. Fordyce writes: "Those hands, which she employs with so much diligence for the advantage of her family, she fails not to stretch out with equal alacrity for the relief of the indigent. She is not so engrossed by the cares of her own household, as to forget the claims of those who have no habitation" (1.216).

${ }^{12}$ Yet all of this industry is still not enough to keep the ladies, their money, and the community employed, so they also open a factory to manufacture carpets and rugs, which serves "to enrich all the country round about" (243). When the narrator visits the factory, he views a scene of pleasant and productive industry: "Here we found several hundreds of people of all ages, from six years old to four-score, employed in various parts of the manufacture, some spinning, some weaving, others dying the worsted, and in short all busy, singing and whistling, with the appearance of general chearfulness, and their neat dress showed them in a condition of proper plenty" (243). The factory also provides further activity for the ladies, as "they themselves undertook to be stewards" and "kept the distribution of the money entirely in their own hands" (243). Furthermore, the financial success of the factory allows the ladies to expand their philanthropic activities, as they use the unexpected profits to finance "a fund for the sick and disabled" (247). Thus, industry prevents idleness, discourages vice, and provides for both the material wellbeing of the community and the philanthropic impetus of the ladies.

${ }^{13}$ Similarly, the first unnamed spinster and her brothers discover at the death their father "their whole inheritance amounted to but four hundred pounds each" (109). The third narrator finds herself without income when her mother, an officer's widow, dies (115).

${ }^{14} \mathrm{Cf}$. The second narrator finds that she is "rendered by my sex less capable of getting a livelihood than my brothers" (109). She serves as a companion to two ladies but finds such work too taxing economically and psychologically (111-13).

${ }^{15}$ While some critics read Millenium Hall as a feminist critique of patriarchy, others, usually approaching the novel from a Marxist-feminist perspective, find the novel far less revolutionary. For example, Lee Cullen Khanna argues that the difficult economic situation for women in the eighteenth century resulted in part from a shift from aristocratic to mercantile values:

What begins to seem clear from these histories is the vulnerability of women, in particular, to a market economy that grants the second or "deficient" sex very little power or security. However well born or well educated, women are liable to 
the loss of status and independence through parental death, bad marriage, disfiguring disease, or even simple gossip. Such volatility in economic fortune speaks to actual fluctuation of material well being in an increasingly expanded and changed economy. Mercantilism was changing the face of power in Britain, enabling the rise of a more substantial middle class while further destabilizing the values and security of the landed gentry and aristocracy. (28)

However, she later conflates mercantilism and patriarchy, asserting that a rejection of mercantile values is also a repudiation of patriarchy: "Scott's vision of a female economy, although carefully couched in the context of decorous behavior, apparent support of the institution of marriage, chaste living and genteel good works, represents a major challenge to patriarchy, mercantilism, and colonialism" (31). Rather than being progressive and feminist, however, the ladies of Millenium Hall seem to be promoting a return to an older, idealized model of patriarchy that fulfills its Christian obligations to those who require protection, such as women, children, the poor, and the disabled. Vincent Carretta even argues that the "feminist" ideas in Scott's novel were accepted by patriarchal society and were "not so much alternatives to contemporary society as complements to it" (309). 


\section{Works Cited}

Allestree, Richard. The Ladies Calling. $2^{\text {nd }}$ ed. 2 vols. Oxford: 1673 . Print.

Armstrong, Nancy. Desire and Domestic Fiction: A Political History of the Novel. Oxford:

Oxford UP, 1987. Print.

The Art of Governing a Wife; with Rules for Batchelors. London: 1747. Print.

Atkinson, Colin B., and Jo Atkinson. "Maria Edgeworth, Belinda, and Women's Rights." EireIreland: A Journal of Irish Studies 19.4 (1984): 94-98. Print.

Austen, Jane. Emma. 1816. Ed. Fiona Stafford. London: Penguin, 2003. Print.

--- Northanger Abbey. 1818. The Novels of Jane Austen. Vol. 5. $3^{\text {rd }}$ ed. Ed. R. W. Chapman.

Oxford: Oxford UP, 1988. Print.

---. Pride and Prejudice. 1813. The Novels of Jane Austen. Vol. 2. $3^{\text {rd }}$ ed. Ed. R. W.

Chapman. Oxford: Oxford UP, 1988. Print.

---. Sense and Sensibility. 1811. The Novels of Jane Austen. Vol. 1. $3^{\text {rd }}$ ed. Ed. R. W.

Chapman. Oxford: Oxford UP, 1988. Print.

Bennett, John. Letters to a Young Lady on a Variety of Useful and Interesting Subjects. $2^{\text {nd }}$ ed. London: 1795. Print.

Brandon, Ruth. Governess: The Lives and Times of the Real Jane Eyres. New York: Walker, 2008. Print.

Burney, Frances. Camilla. 1796. Ed. Edward A. Bloom and Lillian D. Bloom. Oxford: Oxford UP, 1999. Print.

---. Cecilia. 1782. Ed. Margaret Anne Doody and Peter Sabor. Oxford: Oxford UP, 1988.

Print.

---. Evelina. 1778. Ed. Kristina Straub. Boston: Bedford, 1997. Print. 
---. The Journals and Letters of Fanny Burney (Madame D'Arblay). Ed. Joyce Hemlow. Vol 4. Oxford: Clarendon, 1973. Print.

---. The Wanderer; or, Female Difficulties. 1814. Ed. Margaret Anne Doody, Robert L. Mack, and Peter Sabor. Oxford: Oxford UP, 1991. Print.

Butler, Marilyn. Jane Austen and the War of Ideas. Oxford: Clarendon, 1975. Print.

Carretta, Vincent. "Utopia Limited: Sarah Scott's Millenium Hall and The History of Sir George Ellison." The Age of Johnson 5 (1992): 303-25. Print.

Chapone, Hester. Letters on the Improvement of the Mind. London: 1773. Print.

Colley, Linda. Britons: Forging the Nation 1707-1837. New Haven: Yale UP, 1992.

Comitini, Patricia. Vocational Philanthropy and British Women's Writing, 1790-1810:

Wollstonecraft, More, Edgeworth, Wordsworth. Burlington, VT: Ashgate, 2005. Print.

Cooper, Helen. "Persuasion and Power: The Significance of the Mentor in Three Novels by Frances Burney." A Celebration of Frances Burney. Ed. Lorna J. Clark. Newcastle upon Tyne, England: Cambridge Scholars. 112-23. Print.

Cruise, James. “A House Divided: Sarah Scott’s Millenium Hall.” SEL 35 (1995): 555-73.

Print.

Cutting-Gray, Joanne. Woman as "Nobody" and the Novels of Frances Burney. Gainesville: UP of Florida, 1992. Print.

Defoe, Daniel. Moll Flanders. 1722. Ed. David Blewett. New York: Penguin, 1989. Print.

Doody, Margaret Anne. Frances Burney: The Life in the Works. New Brunswick, NJ: Rutgers UP, 1988. Print. 
Dunne, Linda. "Mothers and Monsters in Sarah Robinson Scott's Millenium Hall." Utopian and Science Fiction by Women: Worlds of Difference. Ed. Jane L. Donawerth and Carol A. Kolmerten. Syracuse: Syracuse UP, 1994.

Edgeworth, Maria. Belinda. 1801. Ed. Kathryn Kirkpatrick. Oxford: Oxford UP, 1999. Print. Elliott, Dorice Williams. "Sarah Scott's Millenium Hall and Female Philanthropy.” SEL 35 (1995): 535-53. Print.

Epstein, Julia. The Iron Pen: Frances Burney and the Politics of Women's Writing. Madison: U of Wisconsin P, 1989. Print.

Farnsworth, Rodney. "Mothers, Children, and the Other: Emotions about Children in Staël's Corrine and Austen's Sense and Sensibility." Prism(s): Essays in Romanticism 9 (2001): 123-38. Print.

Fletcher, Anthony. Gender, Sex, and Subordination in England 1500-1800. New Haven: Yale UP, 1995. Print.

Fordyce, James. Sermons to Young Women. $4^{\text {th }}$ ed. 2 vols. London: 1767. Print.

Froide, Amy M. Never Married: Singlewomen in Early Modern England. Oxford: Oxford UP, 2005. Print.

Galperin, William H. The Historical Austen. Philadelphia: U of Pennsylvania P, 2003. Print.

Gisborne, Thomas. An Enquiry into the Duties of the Female Sex. $2^{\text {nd }}$ ed. London: 1797. Print. Goodheart, Eugene. “Emma: Jane Austen’s Errant Heroine.” Sewanee Review 116 (2008): 589604. Print.

Green, Katherine Sobba. The Courtship Novel, 1740-1820: A Feminized Genre. Lexington: UP of Kentucky, 1991. Print. 
Greenfield, Susan C. “'Abroad and at Home': Sexual Ambiguity, Miscegenation, and Colonial Boundaries in Edgeworth's Belinda.” PMLA 112 (1997): 214-228. Print.

---. Mothering Daughters: Novels and the Politics of Family Romance, Frances Burney to Jane Austen. Detroit: Wayne State UP, 2002. Print.

Grossman, Jonathan H. "The Labor of the Leisured in Emma: Class, Manners, and Austen.” Nineteenth-Century Literature 52 (1999):143-64. Print.

Grundy, Isobel. "Why Do They Talk So Much? How Can We Stand It?: John Thorpe and Miss Bates." The Talk in Jane Austen. Ed. Bruce Stovel and Lynn Weinlos Gregg. Edmonton: U of Alberta P, 2002. 41-56.

Gruner, Elizabeth Rose. "The Bullfinch and the Brother: Marriage and Family in Frances Burney's Camilla.” Journal of English and German Philology 93 (1994): 18-34. Print. Halifax, Lord [George Savile]. The Lady's New Year's Gift; or Advice to a Daughter. $4^{\text {th }}$ ed. London: 1692. Print.

Hall, Ronald. "Mishearing, Misreading, and the Language of Listening." The Talk in Jane Austen. Ed. Bruce Stovel and Lynn Weinlos Gregg. Edmonton: U of Alberta P, 2002. $141-48$.

Harvey, Alison. “West Indian Obeah and English 'Obee’: Race, Femininity, and Questions of Colonial Consolidation in Maria Edgeworth's Belinda." New Essays on Maria Edgeworth. Ed. Julie Nash. Aldershot, England: Ashgate, 2006. 1-29. Print.

Hill, Bridget. Women Alone: Spinsters in England, 1660-1850. New Haven: Yale UP, 2001. Print.

Hufton, Olwen. The Prospect Before Her: A History of Women in Western Europe. Vol. 1. New York: Knopf, 1996. Print. 
Johnson, Claudia L. Jane Austen: Women, Politics, and the Novel. Chicago: U of Chicago P, 1988. Print.

Kern, Jean B. "The Old Maid, or 'To Grow Old, and Be Poor, and Laughed At."” Fetter'd or Free?: British Women Novelists, 1670-1815. Ed. Mary Anne Schofield and Cecilia Macheski. Athens, OH: Ohio UP, 1986. 201-14.

Khanna, Lee Cullen. "Utopian Exchanges: Negotiating Difference in Utopia.” Gender and Utopia in the Eighteenth Century: Essays in English and French Utopian Writing. Ed. Nicole Pohl and Brenda Tooley. Burlington, VT: Ashgate, 2007. 17-37. Print.

Kirkpatrick, Kathryn. "Sermons and Strictures: Conduct-Book Propriety and Property Relations in Late Eighteenth-Century England." History, Gender, and Eighteenth-Century Literature. Ed. Beth Fowkes Tobin. Athens: U of Georgia P, 1994. 198-226. Print. Kittredge, Katharine. “'The Ag'd Dame to Venery Inclin'd': Images of Sexual Older Women in Eighteenth-Century Britain.” Power and Poverty: Old Age in the Pre-Industrial Past. Ed. Susannah R. Ottaway, L. A. Botelho, and Katharine Kittredge. Westport, CT: Greenwood, 2002. 247-63.

Klekar, Cynthia. "'Her Gift Was Compelled': Gender and the Failure of the 'Gift' in Cecilia" Eighteenth-Century Fiction 18 (2005): 107-26. Print.

Kowaleski-Wallace, Beth. “Home Economics: Domestic Ideology in Maria Edgeworth’s Belinda." The Eighteenth Century 29.3 (1988): 242-62. Print.

Lanser, Susan S. "Singular Politics: The Rise of the British Nation and the Production of the Old Maid." Singlewomen in the European Past, 1250-1800. Ed. Judith M. Bennett and Amy M. Froide. Philadelphia: U of Pennsyvania P, 1999. 297-323. Print. 
Lenta, Margaret. "Jane Fairfax and Jane Eyre: Educating Women.” ARIEL 12.4 (1981): 27-41. Print.

Lightfoot, Marjorie. “'Morals for Those That Like Them': The Satire of Edgeworth's Belinda, 1801.” Eire-Ireland: A Journal of Irish Studies 29.4 (1994): 117-31. Print.

Looser, Devoney. Women Writers and Old Age in Great Britain, 1750-1850. Baltimore: Johns Hopkins UP, 2008.

MacDonald, Susan Peck. "Jane Austen and the Tradition of the Absent Mother." The Lost Tradition: Mothers and Daughters in Literature. Ed. Cathy N. Davidson and E. M. Broner. New York: Ungar, 1980. 58-69. Print.

Martin, Graham. “Austen and Class.” Women's Writing 5 (1998): 131-44. Print.

Mason, Nicholas. “Class, Gender, and Domesticity in Maria Edgeworth’s Belinda." The Eighteenth-Century Novel. Vol. 1. New York: AMS, 2001. Print.

McCann, Andrew. "Conjugal Love and the Enlightenment Subject: The Colonial Context of Non-Identity in Maria Edgeworth's Belinda." Novel: A Forum on Fiction 17.3 (1996): 222-34. Print.

McGonegal, Julie. "The Tyranny of Gift Giving: The Politics of Generosity in Sarah Scott's Millenium Hall and Sir George Ellison.” Eighteenth-Century Fiction 19.3 (2007); 291306. Print.

McMaster, Juliet. "Class.” The Cambridge Companion to Jane Austen. Ed. Edward Copeland and Juliet McMaster. Cambridge: Cambridge UP, 1997. 115-30. Print.

Miller, D. A. The Novel and the Police. Berkeley: U of California P, 1988. Print. Monaghan, David. "Jane Austen and the Position of Women." Jane Austen in a Social Context. Ed. David Monaghan. New York: Macmillan, 1981. 105-21. Print. 
Montwieler, Katherine. “Reading Disease: The Corrupting Performance of Edgeworth's Belinda." Women's Writing 12 (2005): 347-68. Print.

More, Hannah. Strictures on the Modern System of Female Education. London: Cadell and Davies, 1799. Print.

Nash, Julie. “'Standing in Distress Between Tragedy and Comedy’: Servants in Maria Edgeworth's Belinda." New Essays on Maria Edgeworth. Ed. Julie Nash. Aldershot, England: Ashgate, 2006. 161-74. Print.

Nokes, David. Jane Austen: A Life. New York: Farrar, Straus, and Giroux, 1997. Print.

Parker, Mark. "The End of Emma: Drawing the Boundaries of Class in Austen." Journal of English and Germanic Philology 91 (1992): 344-59. Print.

Pearson, Jacqueline. The Prostituted Muse: Images of Women and Women Dramatists 16421737. New York: St. Martin’s, 1988. Print.

Perry, Ruth. Novel Relations: The Transformation of Kinship in English Literature and Culture, 1748-1818. Cambridge: Cambridge UP, 2006.

Peterson, M. Jeanne. "The Victorian Governess: Status Incongruence in Family and Society." Victorian Studies 14 (1970): 7-26. Print.

Poovey, Mary. The Proper Lady and the Woman Writer: Ideology as Style in the Works of Mary Wollstonecraft, Mary Shelley, and Jane Austen. Chicago: U of Chicago P, 1984. Print. Pope, Alexander. The Poems of Alexander Pope. Ed. John Butt. New Haven: Yale UP, 1963. Print.

Porter, Agnes. A Governess in the Age of Jane Austen: The Journals and Letters of Agnes Porter. Ed. Joanna Martin. London: Hambledon, 1998. Print. 
Renton, Alice. Tyrant or Victim?: A History of British Governesses. London: Weidenfeld and Nicolson, 1991. Print.

Richardson, Samuel. Pamela. 1740. Ed. Thomas Keymer and Alice Wakely. Oxford: Oxford UP, 1974. Print.

Rizzo, Betty. Companions Without Vows: Relationships Among Eighteenth-Century British Women. Athens: U of Georgia P, 1994. Print.

Rogers, Kay. “Deflation of Male Pretentions in Fanny Burney's Cecilia.” Women's Studies 15 (1988): 87-96. Print.

Scott, Sarah. A Description of Millenium Hall. 1762. Ed. Gary Kelly. Orchard Park, NY: Broadview, 1995. Print.

---. The History of Sir George Ellison. 1766. Ed. Betty Rizzo. Lexington: UP of Kentucky, 1996. Print.

Sheridan, Richard Brinsley. The Duenna: A Comic Opera. 1775. The School for Scandal and Other Plays. Ed. Michale Cordner. Oxford: Oxford UP, 1998. 87-143. Print.

Shoemaker, Robert. Gender in English Society 1650-1850: The Emergence of Separate Spheres? London: Longman, 1998. Print.

Sinfield, Alan. Fautlines: Cultural Materialism and the Politics of Dissident Reading. Berkeley: U of Califronia P, 1992. Print.

Smith, Phoebe A. "Sense and Sensibility and 'The Lady's Law': The Failure of Benevolent Paternalism." CEA Critic: An Official Journal of the College English Association 55.3 (1993): 3-25. Print.

Staves, Susan. Married Women's Separate Property in England, 1660-1833. Cambridge, MA: Harvard UP, 1990. Print. 
Straub, Kristina. Divided Fictions: Fanny Burney and Feminine Strategy. Lexington: UP of Kentucky, 1987. Print.

Tanner, Tony. Jane Austen. Cambridge: Harvard UP, 1986. Print.

Thaddeus, Janice Farrar. Frances Burney: A Literary Life. New York: St. Martin's, 2000. Print.

Thompson, James. Between Self and World: The Novels of Jane Austen. University Park:

Pennsylvania State UP, 1988. Print.

Tobin, Beth Fowkes. Superintending the Poor: Charitable Ladies and Paternal Landlords in British Fiction, 1770-1860. New Haven: Yale UP, 1993. Print.

Todd, Janet. The Secret Life of Aphra Behn. New Brunswick, NJ: Rutgers UP, 1997. Print.

---. The Sign of Angellica: Women, Writing and Fiction, 1660-1800. New York: Columbia UP, 1989. Print.

Tomalin, Claire. The Life and Death of Mary Wollstonecraft. London: Weidenfeld and Nicolson, 1974. Print.

Turner, Cheryl. Living by the Pen: Women Writers in the Eighteenth Century. London: Routledge, 1994. Print.

Weiss, Deborah. “The Extraordinary Ordinary Belinda: Maria Edgeworth’s Female Philosopher." Eighteenth-Century Fiction 19 (2007): 441-61. Print.

White, Gabrielle D. V. Jane Austen in the Context of Abolition. New York: Palgrave McMillan, 2006. Print.

Wollstonecraft, Mary. Original Stories. 1796. The Works of Mary Wollstonecraft. Ed. Janet Todd and Marilyn Butler. Vol. 4. New York: New York UP, 1989. 353-450. Print.

---. Thoughts on the Education of Daughters. 1787. The Works of Mary Wollstonecraft. Ed. Janet Todd and Marilyn Butler. Vol. 4. New York: New York UP, 1989. 1-49. Print. 
---. Vindication of the Rights of Woman. 1792. The Works of Mary Wollstonecraft. Ed. Janet Todd and Marilyn Butler. Vol. 5. New York: New York UP, 1989. 79-266. Print. ---. The Wrongs of Woman. 1798. The Works of Mary Wollstonecraft. Ed. Janet Todd and Marilyn Butler. Vol. 1. New York: New York UP, 1989. 75-184. Print.

Wrigley, E. A., and R. S. Schofield. The Population History of England 1541-1871: A Reconstruction. Cambridge: Harvard UP, 1981. Print.

Zomchick, John. "Satire and the Bourgeois Subject in Frances Burney’s Evelina." Cutting Edges: Postmodern Critical Essays on Eighteenth Century Satire. Ed. James E. Gill. Knoxville: U of Tennessee P, 1995. Print. 